Prepared in cooperation with the U.S. Fish and Wildlife Service

\title{
Estimation of Streamflow Characteristics for Charles M. Russell National Wildlife Refuge, Northeastern Montana
}

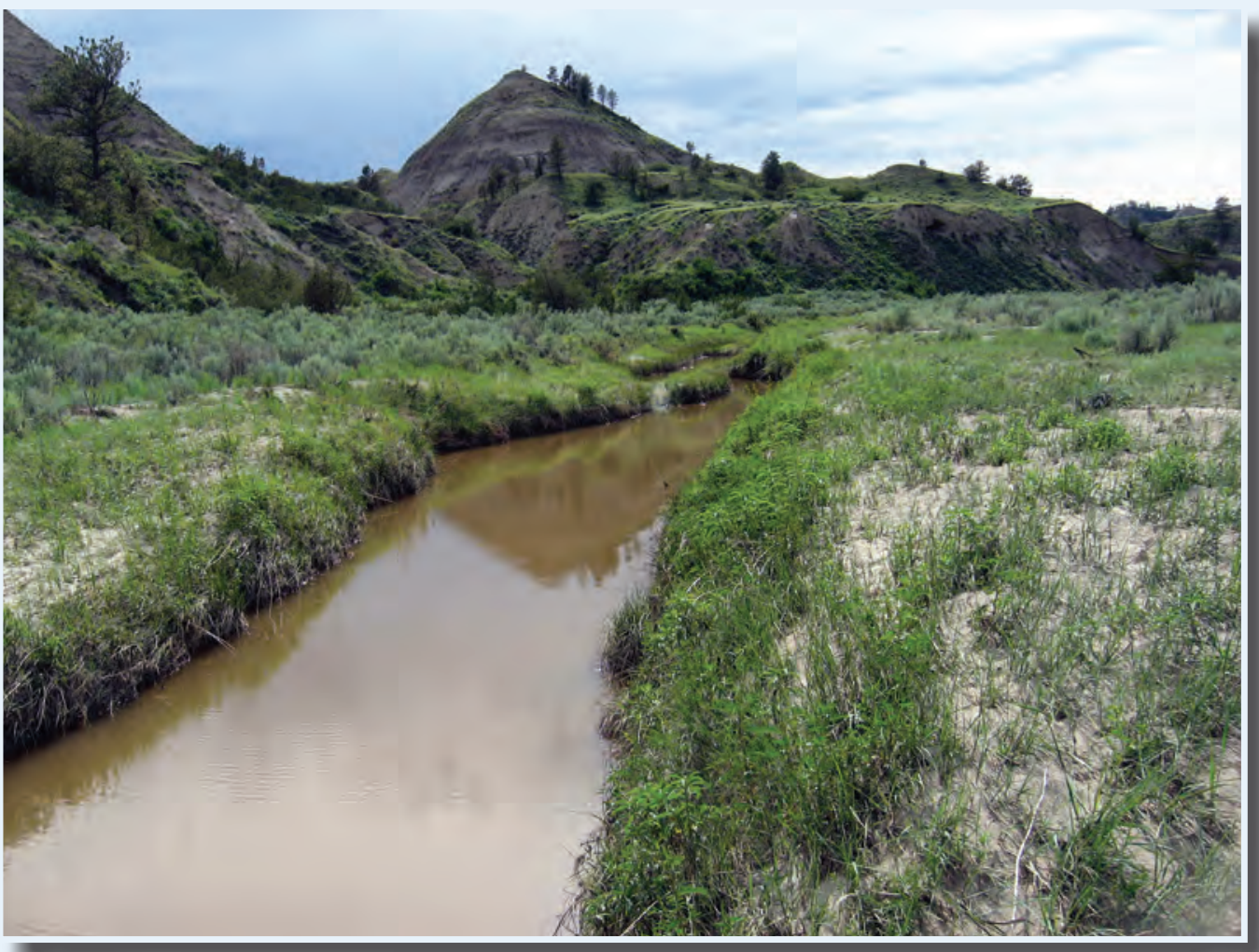

Scientific Investigations Report 2009-5009 
Cover photograph: Hell Creek upstream from Hart Creek near Charles M. Russell National Wildlife Refuge. Photograph by Martha Kaufmann, World Wildlife Fund, taken June 2007. Published with permission by Martha Kaufmann. 


\section{Estimation of Streamflow Characteristics for Charles M. Russell National Wildlife Refuge, Northeastern Montana}

By Steven K. Sando, Timothy J. Morgan, DeAnn M. Dutton, and Peter M. McCarthy

Prepared in cooperation with the U.S. Fish and Wildlife Service

Scientific Investigations Report 2009-5009 


\title{
U.S. Department of the Interior DIRK KEMPTHORNE, Secretary
}

\section{U.S. Geological Survey \\ Mark D. Myers, Director}

\section{U.S. Geological Survey, Reston, Virginia: 2009}

\author{
This and other USGS information products are available at $h t t p: / / s t o r e . u s g s . g o v /$ \\ U.S. Geological Survey \\ Box 25286, Denver Federal Center \\ Denver, CO 80225 \\ To learn about the USGS and its information products visit http://www.usgs.gov/ \\ 1-888-ASK-USGS
}

Any use of trade, product, or firm names is for descriptive purposes only and does not imply endorsement by the U.S. Government.

Although this report is in the public domain, permission must be secured from the individual copyright owners to reproduce any copyrighted materials contained within this report.

Suggested citation:

Sando, S.K., Morgan, T.J., Dutton, D.M., and McCarthy, P.M., 2009, Estimation of streamflow characteristics for Charles M. Russell National Wildlife Refuge, northeastern Montana: U.S. Geological Survey Scientific Investigations Report 2009-5009, 60 p. 


\section{Contents}

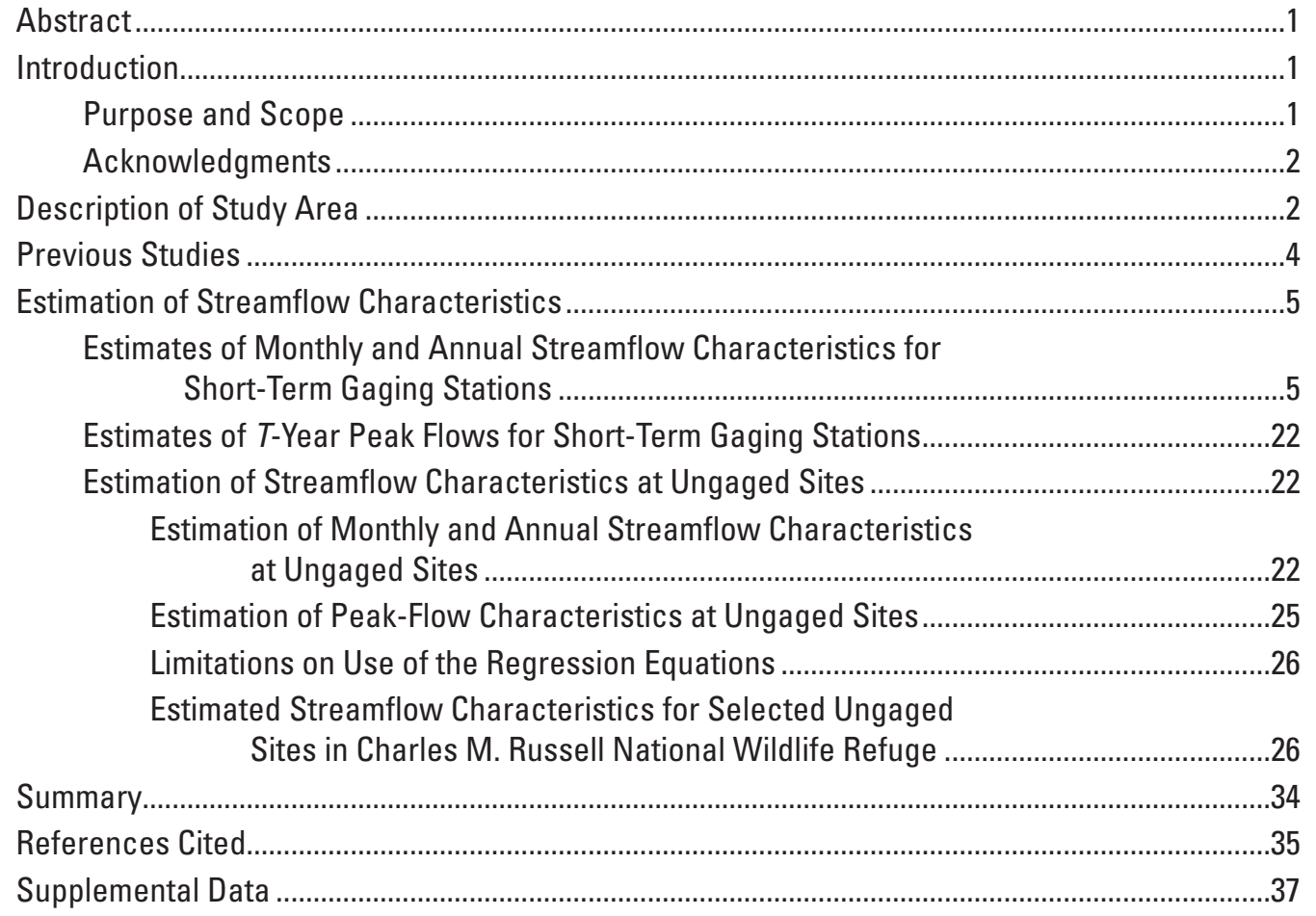

\section{Figures}

1. Map showing locations of study area, gaging stations used in various analyses, and Charles M. Russell National Wildlife Refuge, northeastern Montana...

2-7. Graphs showing:

2. Monthly precipitation and temperature characteristics (1971-2000) for Jordan, Mont. .4

3. Annual mean streamflow for selected gaging stations .............................................

4. Regional Adjustment Relationship regression relations used to estimate the long-term 50-percent exceedance (median) and mean annual streamflows for the short-term gaging stations

5. Comparison of actual study period (water years 2000-2004) and estimated long-term selected monthly streamflow characteristics for the short-term gaging stations.

6. Comparison of actual study period (water years 2000-2004) and actual long-term selected monthly streamflow characteristics for selected long-term index gaging stations used in the Regional Adjustment Relationship.

7. Regional Adjustment Relationship regression relations used to estimate the 2-year recurrence interval peak flow for the short-term gaging stations 
8. Map showing locations of selected ungaged sites on tributaries that cross Charles M. Russell National Wildlife Refuge, northeastern Montana

9-11. Graphs showing:

9. Estimated long-term monthly streamflow characteristics for selected ungaged sites

10. Estimated annual streamflow for various exceedance probabilities for selected ungaged sites.

11. Estimated 1.5-, 2-, and 2.33-year recurrence interval peak flows for selected ungaged sites.

\section{Tables}

1. Site information for selected gaging stations, northeastern Montana

2. Regression equations used to estimate long-term monthly and annual streamflow characteristics for the short-term gaging stations

3. Estimation coefficients used to estimate long-term streamflow characteristics

4. Actual study period (water years 2000-2004) mean monthly and annual streamflows and estimated long-term monthly and annual streamflow characteristics for the short-term gaging stations.

5. Regression equations for estimating peak-flow characteristics for the short-term gaging stations.

6. Estimates of peak-flow characteristics for the short-term gaging stations.

7. Selected basin and climatic characteristics considered as potential explanatory variables in regression analyses for estimating streamflow characteristics at ungaged sites

8. Regression equations for estimating annual streamflow characteristics at ungaged sites.

9. Regression equations for estimating peak-flow characteristics at ungaged sites

10. Ranges for basin characteristics used to develop regression equations for estimating streamflow characteristics at ungaged sites.

Supplements 1-8.

1. Monthly and annual streamflow characteristics for long-term index gaging stations used in the Regional Adjustment Relationship (RAR)

2. Selected peak-flow information for long-term index gaging stations used in the Regional Adjustment Relationship.

3. Long-term monthly and annual streamflow characteristics for selected gaging stations used to develop regression equations

4. Selected basin and climatic characteristics for gaging stations used in various analyses to estimate streamflow characteristics

5. Selected peak-flow characteristics for selected gaging stations used to develop regression equations.

6. Selected basin and climatic characteristics for selected ungaged sites on tributaries that cross Charles M. Russell National Wildlife Refuge

7. Estimates of long-term monthly and annual streamflow characteristics for selected ungaged sites on tributaries that cross Charles M. Russell National Wildlife Refuge.

8. Estimates of selected peak-flow characteristics for selected ungaged sites on tributaries that cross Charles M. Russell National Wildlife Refuge 


\section{Conversion Factors, Datum, Acronyms, and Definitions for Streamflow Terminology}

\begin{tabular}{lcl}
\hline Multiply & By & To obtain \\
\hline inch (in.) & Length & \\
inch (in.) & 2.54 & centimeter $(\mathrm{cm})$ \\
foot (ft) & 25.4 & millimeter $(\mathrm{mm})$ \\
mile (mi) & 0.3048 & meter $(\mathrm{m})$ \\
& 1.609 & kilometer $(\mathrm{km})$ \\
\hline acre & Area & \\
acre & 4,047 & square meter $\left(\mathrm{m}^{2}\right)$ \\
acre & 0.4047 & hectare $($ ha) \\
square mile $\left(\mathrm{mi}^{2}\right)$ & 0.004047 & square kilometer $\left(\mathrm{km}^{2}\right)$ \\
square mile $\left(\mathrm{mi}^{2}\right)$ & 259.0 & hectare $($ ha) \\
\hline & 2.590 & square kilometer $\left(\mathrm{km}^{2}\right)$ \\
\hline cubic foot per second $\left(\mathrm{ft}^{3} / \mathrm{s}\right)$ & Flow rate & \\
\hline & 0.02832 & cubic meter per second $\left(\mathrm{m}^{3} / \mathrm{s}\right)$ \\
\hline foot per mile $\left(\mathrm{ft} / \mathrm{mi}^{2}\right)$ & Slope & meter per kilometer $\left(\mathrm{m} / \mathrm{km}^{2}\right)$ \\
\hline
\end{tabular}

Temperature in degrees Fahrenheit $\left({ }^{\circ} \mathrm{F}\right)$ may be converted to degrees Celsius $\left({ }^{\circ} \mathrm{C}\right)$ as follows:

$$
{ }^{\circ} \mathrm{C}=\left({ }^{\circ} \mathrm{F}-32\right) / 1.8
$$

Vertical coordinate information is referenced to the North American Vertical Datum of 1988 (NAVD 88).

Horizontal coordinate information is referenced to the North American Datum of 1983 (NAD 83).

Elevation, as used in this report, refers to distance above the vertical datum.

Water year is the 12-month period from 0ctober 1 through September 30 of the following calendar year. The water year is designated by the calendar year in which it ends. For example, water year 2008 is the period from October 1, 2007, through September 30, 2008.

\section{Acronyms}

BLM Bureau of Land Management

CMR Charles M. Russell National Wildlife Refuge

EYR equivalent years of record - the number of years of record at a gaged site that would be needed to provide the same reliability as the regression estimate

FWS U.S. Fish and Wildlife Service

GIS geographic information system

GLS generalized least squares

NHDPlus National Hydrography Dataset Plus

OLS ordinary least squares 
PK1.5 1.5-year recurrence interval peak flow

PK2 2-year recurrence interval peak flow

PK2.33 2.33-year recurrence interval peak flow

PKM mean of annual peak flows for specified period of years

$\mathrm{p}$-value significance level or probability of obtaining a value of a test statistic at least as extreme as the one observed given that the null hypothesis is true

0.90 90-percent exceedance streamflow

0.80 80-percent exceedance streamflow

$0.50 \quad 50$-percent exceedance streamflow

0.20 20-percent exceedance streamflow

$\mathrm{OM} \quad$ mean streamflow

PRISM Parameter-elevation Regressions on Independent Slopes Model

RAR Regional Adjustment Relationship

SEE average standard error of estimate (also sometimes referred to as the root mean square error or the standard deviation of the residuals)

SEP average standard error of prediction

USGS U.S. Geological Survey

WLS weighted least squares

\section{Definitions for Streamflow Terminology}

\begin{tabular}{|c|c|}
\hline & year \\
\hline annual peak flow & $\begin{array}{l}\text { maximum instantaneous streamflow that occurred during a single } \\
\text { specified year }\end{array}$ \\
\hline daily mean streamflow & mean streamflow for a single specified day \\
\hline mean annual streamflow & $\begin{array}{l}\text { arithmetic mean of all annual mean streamflows for the period of } \\
\text { record or for a specific period of multiple years }\end{array}$ \\
\hline mean daily streamflow & $\begin{array}{l}\text { arithmetic mean of all daily mean streamflows for a specified day } \\
\text { for the period of record or for a specific period of multiple years }\end{array}$ \\
\hline mean monthly streamflow & $\begin{array}{l}\text { arithmetic mean of all monthly mean streamflows for a specified } \\
\text { month for the period of record or for a specific period of multiple } \\
\text { years }\end{array}$ \\
\hline mean peak flow & $\begin{array}{l}\text { arithmetic mean of all annual peak flows for the period of record or } \\
\text { for a specific period of multiple years }\end{array}$ \\
\hline monthly mean streamflow & $\begin{array}{l}\text { arithmetic mean of all daily mean streamflows for a single specified } \\
\text { month in a single specified year }\end{array}$ \\
\hline$T$-year peak flow & $\begin{array}{l}\text { peak flow determined by statistical analysis of annual peak flows } \\
\text { for the period of record or for a specific period of multiple years to } \\
\text { occur on average once every } T \text { years }\end{array}$ \\
\hline
\end{tabular}




\title{
Estimation of Streamflow Characteristics for Charles M. Russell National Wildlife Refuge, Northeastern Montana
}

\author{
By Steven K. Sando, Timothy J. Morgan, DeAnn M. Dutton, and Peter M. McCarthy
}

\section{Abstract}

Charles M. Russell National Wildlife Refuge (CMR) encompasses about 1.1 million acres (including Fort Peck Reservoir on the Missouri River) in northeastern Montana. To ensure that sufficient streamflow remains in the tributary streams to maintain the riparian corridors, the U.S. Fish and Wildlife Service is negotiating water-rights issues with the Reserved Water Rights Compact Commission of Montana. The U.S. Geological Survey, in cooperation with the U.S. Fish and Wildlife Service, conducted a study to gage, for a short period, selected streams that cross CMR, and analyze data to estimate long-term streamflow characteristics for CMR. The long-term streamflow characteristics of primary interest include the monthly and annual 90-, 80-, 50-, and 20-percent exceedance streamflows and mean streamflows (Q.90, Q.80, Q.50, Q.20, and QM, respectively), and the 1.5-, 2-, and 2.33year peak flows (PK1.5, PK2, and PK2.33, respectively).

The Regional Adjustment Relationship (RAR) was investigated for estimating the monthly and annual Q.90, Q.80, Q.50, Q.20, and QM, and the PK1.5, PK2, and PK2.33 for the short-term CMR gaging stations (hereinafter referred to as CMR stations). The RAR was determined to provide acceptable results for estimating the long-term Q.90, Q.80, Q.50, Q.20, and QM on a monthly basis for the months of March through June, and also on an annual basis. For the months of September through January, the RAR regression equations did not provide acceptable results for any long-term streamflow characteristic. For the month of February, the RAR regression equations provided acceptable results for the long-term Q.50 and QM, but poor results for the long-term Q.90, Q.80, and Q.20. For the months of July and August, the RAR provided acceptable results for the long-term Q.50, Q.20, and QM, but poor results for the long-term Q.90 and Q.80. Estimation coefficients were developed for estimating the long-term streamflow characteristics for which the RAR did not provide acceptable results. The RAR also was determined to provide acceptable results for estimating the PK1.5., PK2, and PK2.33 for the three CMR stations that lacked suitable peak-flow records.

Methods for estimating streamflow characteristics at ungaged sites also were derived. Regression analyses that relate individual streamflow characteristics to various basin and climatic characteristics for gaging stations were performed to develop regression equations to estimate streamflow characteristics at ungaged sites. Final equations for the annual Q.50, Q.20, and QM are reported. Acceptable equations also were developed for estimating QM for the months of February, March, April, June, and July, and Q.50, Q.20, and QM on an annual basis. However, equations for QM for the months of February, March, April, June, and July were determined to be less consistent and reliable than the use of estimation coefficients applied to the regression equation results for the annual QM. Acceptable regression equations also were developed for the PK1.5, PK2, and PK2.33.

\section{Introduction}

Charles M. Russell National Wildlife Refuge (CMR) encompasses about 1.1 million acres (including Fort Peck Reservoir on the Missouri River) in northeastern Montana. CMR consists of rugged land bordering the Missouri River, generally termed the Missouri River Breaks. The Missouri River Breaks provides important habitat, including riparian corridors along Missouri River tributary streams, for numerous animals and plants in CMR. To ensure that sufficient streamflow remains in the tributary streams to maintain the riparian corridors, the U.S. Fish and Wildlife Service (FWS) is negotiating water-rights issues with the Reserved Water Rights Compact Commission of Montana. These negotiations require accurate information about current and long-term streamflow characteristics for Missouri River tributary streams that cross CMR. However, there is very little long-term streamflow data for these streams. Thus, the U.S. Geological Survey (USGS), in cooperation with the FWS, conducted a study to gage, for a short period, selected streams that cross CMR, and analyze data to estimate long-term streamflow characteristics for CMR.

\section{Purpose and Scope}

The purpose of this report is to describe methods to estimate streamflow characteristics for CMR. The report presents (1) methods and results of analyses to estimate long-term 
streamflow characteristics for short-term gaging stations and (2) methods and results of analyses to develop regional regression equations that estimate long-term streamflow characteristics at ungaged sites in or near CMR.

\section{Acknowledgments}

Special thanks are given to Patricia J. Fiedler, Danielle L. Kepford, and Megan A. Estep of the U.S. Fish and Wildlife Service for their support of this study. Technical reviews by Daniel G. Driscoll and Charles Parrett of the U.S. Geological survey are greatly appreciated.

\section{Description of Study Area}

The study area (fig. 1) is defined by the drainage boundary of the Missouri River between the points where the river enters and exits CMR; the study area does not include the drainage area of the Musselshell River upstream from where this river enters CMR. The study area encompasses about 8,260 $\mathrm{mi}^{2}$ and includes parts of Fergus, Phillips, Petroleum, Garfield, Valley, McCone, Prairie, Custer, and Rosebud Counties in northeastern Montana.

CMR (originally designated as the Fort Peck Game Range) was established by an executive order in 1936 that withdrew about 1.1 million acres (including the 245,000-acre Fort Peck Reservoir) from the public domain (U.S. Fish and Wildlife Service, 2006). Tributary streams that cross CMR that are of primary interest in this study are those identified by solid lines in the 1:100,000-scale National Hydrography Dataset (U.S. Geological Survey, 2007), but excluding the Musselshell River. The watersheds of these streams are within the Northwestern Great Plains and/or Northwestern Glaciated Plains ecoregions described by Woods and others (2002) and range in area from 58 to $2,830 \mathrm{mi}^{2}$. CMR itself is almost entirely within "river breaks" topography adjacent to major stream channels and characterized by very highly dissected terrain, steep slopes, erodible clayey soils, and high runoff potential.

Predominant vegetation in CMR includes native grasses (including grama, needle grass, western wheatgrass, and buffalo grass), several shrub species (including sagebrush, greasewood, buffaloberry, and chokecherry), and coniferous trees (including juniper, ponderosa pine, and Douglas fir) that occur in scattered patches of woodland. Wildlife is abundant and includes mule and white-tailed deer, elk, bighorn sheep, antelope, coyote, bobcat, beaver, sharp-tailed and sage grouse, and numerous other species (U.S. Fish and Wildlife Service, 2006).

About $1,720 \mathrm{mi}^{2}$ of the $8,260 \mathrm{mi}^{2}$ study area lies within CMR where land use predominantly is shrub and mixed rangeland managed for wildlife habitat. Cattle grazing is allowed but is strictly regulated to prevent degradation of wildlife habitat. Land use for most of the study area outside of CMR is grazed grass, shrub, or mixed rangeland; relatively small areas are cropland, pasture, or mixed forest.

The geology of the study area is dominated by shale, siltstone, and sandstone. Most of the study area is underlain by the Tertiary Fort Union Formation and the Upper Cretaceous Hell Creek Formation, Fox Hills Sandstone, and Bearpaw Shale. The Fort Union Formation crops out over about 39 percent of the study area and consists of sandstone, siltstone, and shale interbedded with thick continuous coal beds (Frahme, 1979). The Hell Creek Formation crops out over about 20 percent of the study area and predominantly is soft claystone but varies in composition from shale to mediumgrained sandstone and also has intermittent concretions (Jensen and Varnes, 1964). The Fox Hills Sandstone crops out over about 4 percent of the study area and ranges from soft claystone to fine sandstone. Cementation is variable but more pronounced in the upper part of this formation resulting in relatively erosion-resistant rimrock features (Jensen and Varnes, 1964) in some areas of exposure. The Bearpaw Shale crops out over about 33 percent of the study area and is dark grey marine shale with discontinuous interbedded silt and sand layers, and concretions (Jensen and Varnes, 1964). Where exposed at the surface, the Bearpaw Shale generally is highly erodible. The geologic characteristics of the study area contribute to the river breaks topography in areas where highly erodible shales occur at the surface and badlands topography in areas where materials with more variable erosive characteristics occur. Soil characteristics in the study area also are profoundly influenced by the bedrock from which the soils are derived. In general, soils within the study area are very fine grained (ranging from clays to silty clay loam) and poorly drained (Frahme, 1979).

The general climate of the study area is semiarid continental and characterized by relatively low precipitation, cold winters, hot summers, and extreme variations in both precipitation and temperatures. Monthly (1971-2000) precipitation and temperature characteristics for Jordan, Mont., located within the study area south of CMR (fig. 1) are presented in figure 2 (Western Regional Climate Center, 2006). Average annual temperature at Jordan is $44.0^{\circ} \mathrm{F}$. On average, coldest temperatures occur in January (mean monthly temperature of $14.1^{\circ} \mathrm{F}$ ) and warmest temperatures occur in July (mean monthly temperature of $71.4^{\circ} \mathrm{F}$ ). Average annual precipitation is 12.9 in.; about 70 percent occurs as rainfall during the months of May through September, and about 50 percent occurs during May through July. Cooper and Jean (2001) noted that although precipitation decreases in late summer in the CMR area, July through September precipitation in the area averages about 0.5 to $1.0 \mathrm{in}$. more than sites in western Montana that have about the same average annual precipitation. They also indicated that convective thunderstorms generally account for more of the late summer precipitation than frontal systems. 

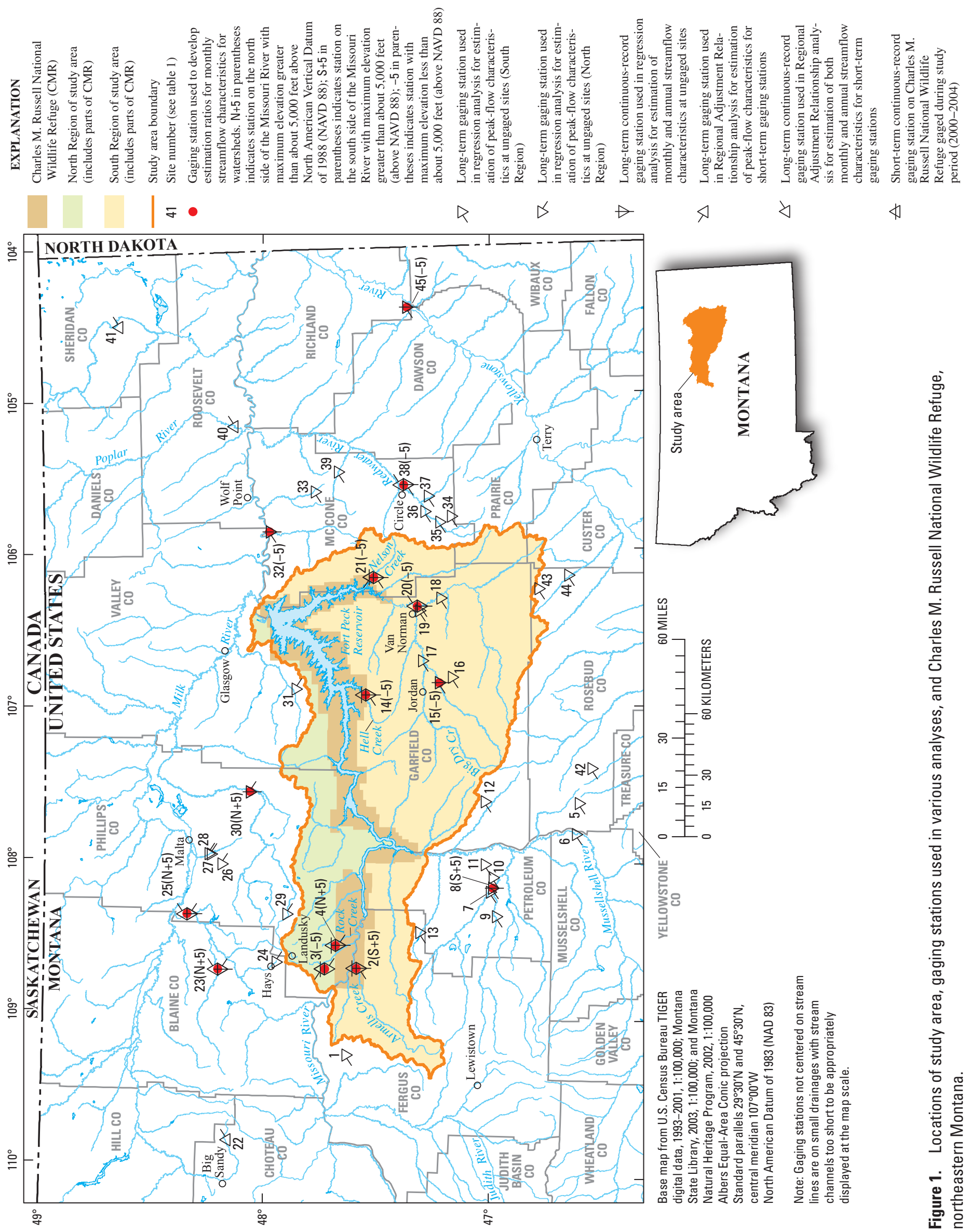


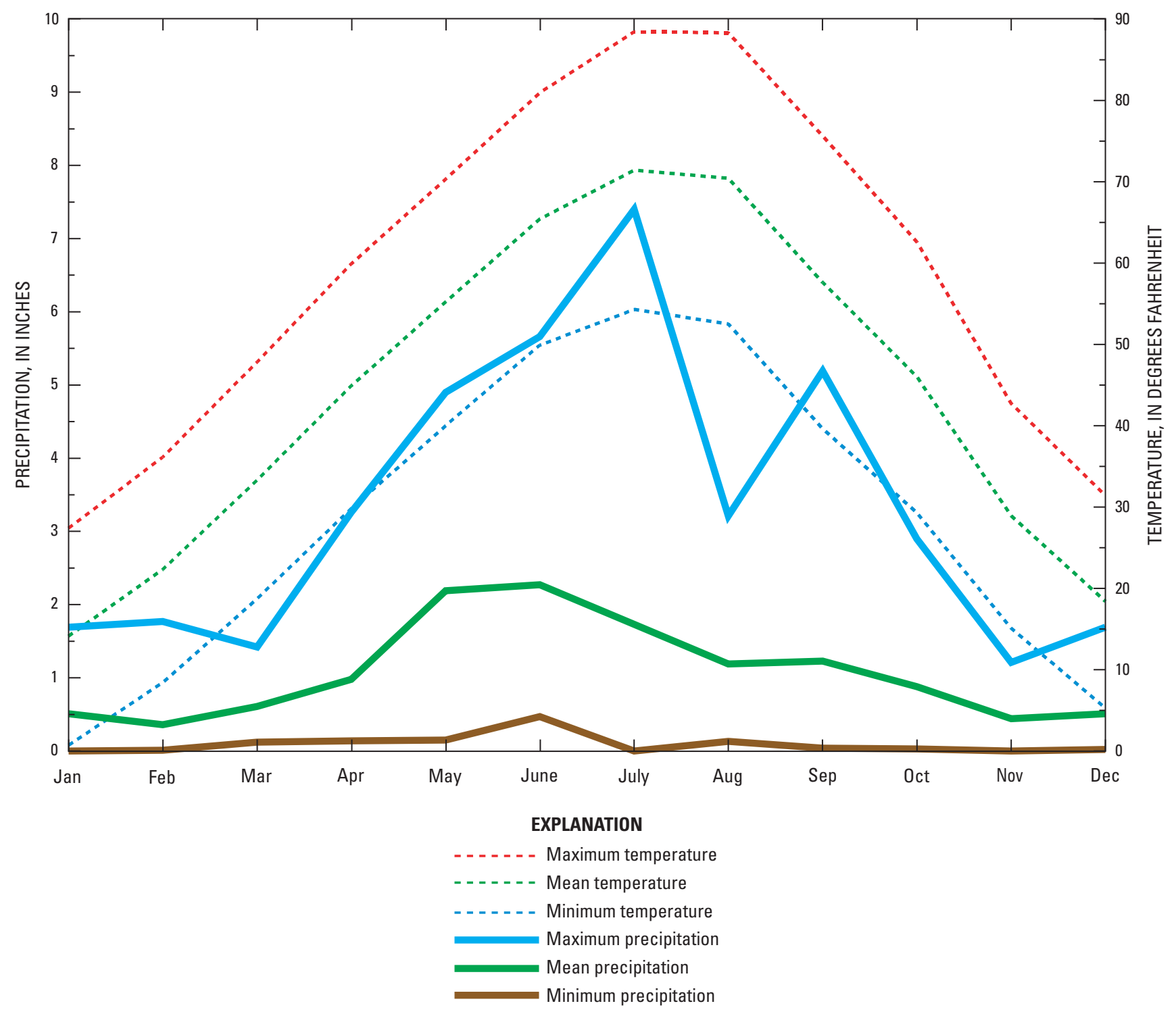

Figure 2. Monthly precipitation and temperature characteristics (1971-2000) for Jordan, Mont. Data from Western Regional Climate Center (2006).

\section{Previous Studies}

Omang and Parrett (1984) developed ordinary least squares (OLS) regression equations that relate mean annual streamflow to various basin and climatic characteristics for estimating mean annual streamflow at ungaged sites in central and eastern Montana. These regression equations covered a larger area than the study area of this report, used streamflow data through water year 1982, and were developed by using manually determined basin characteristics. Omang and Parrett (1984) described the reliability of the regression equations that they developed by using the average standard error of estimate (SEE, also referred to as the root mean square error or the standard deviation of the residuals). The SEE is a measure of the overall reliability of regression equations, and smaller values of SEE generally indicate better reliability of regression equations than do larger values. The study area described in this report falls within two regions defined in Omang and Parrett (1984): Region 1 (north of the Missouri River) and Region 2 (south of the Missouri River). For Region 1, Omang and Parrett (1984) considered 17 gaging stations and developed a regression equation for mean annual streamflow with an SEE of 31 percent. For Region 2, Omang and Parrett (1984) considered 27 gaging stations and developed a three-variable regression equation for mean annual streamflow with an SEE of 51 percent, a two-variable regression equation with an SEE of 62 percent, and a 1-variable equation with an SEE of 64 percent. The regression equations developed by Omang and Parrett (1984) require manual determination of basin characteristics (which is labor intensive), were developed from data 
only through water year 1982, and did not specifically address streams in CMR. Thus, the methods described in the following sections of this report are more conveniently applied and are considered to provide more consistent and reliable results than the methods described by Omang and Parrett (1984).

Parrett and Johnson (2003) developed generalized least squares (GLS) regression equations that relate peak-flow characteristics to various basin and climatic characteristics for estimating peak flows having recurrence intervals of 2 , $5,10,25,50,100,200$, and 500 years ( $T$-year peak flows) at ungaged sites for all of Montana. Methods for estimating only the 2-year peak flow are most relevant to the specific objectives of this study of streamflow characteristics for CMR. The Parrett and Johnson (2003) regression equations covered a larger area than the study area of this report, used streamflow data through water year 1998, and were developed by using manually determined basin characteristics. Parrett and Johnson (2003) described the reliability of the regression equations that they developed by using the average standard error of prediction (SEP), which generally is similar to the SEE. However, the SEP incorporates time-sampling error (accounted for in the more rigorous GLS regression), which is not incorporated in the SEE. Smaller values of SEP generally indicate better reliability of regression equations than do larger values. The study area described in this report falls within two regions defined in Parrett and Johnson (2003): Northeast Plains Region and East-Central Plains Region. For the Northeast Plains Region, Parrett and Johnson (2003) considered 57 gaging stations and developed a regression equation for the 2-year peak flow with an average SEP of 91.0 percent. For the East-Central Plains Region, Parrett and Johnson (2003) considered 85 gaging stations and developed a regression equation for the 2-year peak flow with an average SEP of 99.9 percent. The regression equations developed by Parrett and Johnson (2003) require manual determination of basin characteristics (which is labor intensive), were developed from data only through water year 1998, and did not specifically address streams in CMR. Thus, the methods described in the following sections of this report are more conveniently applied and are considered to provide more consistent and reliable results than the methods described by Parrett and Johnson (2003).

\section{Estimation of Streamflow Characteristics}

To address the need for streamflow information in CMR, a three-phased approach was used that involved (1) collecting continuous records of daily mean streamflow for a 5-year period (water years 2000-2004, hereinafter referred to as the study period) for five streams that cross CMR, (2) estimating long-term streamflow characteristics for the five gaging stations by using relations between study-period streamflow characteristics and long-term streamflow characteristics for nearby long-term gaging stations to adjust recorded study- period streamflow characteristics, and (3) developing regional regression equations to relate streamflow characteristics to basin characteristics. The long-term streamflow characteristics of primary interest include the monthly and annual 90-, 80-, 50-, and 20-percent exceedance streamflows and mean streamflows (Q.90, Q.80, Q.50, Q.20, and QM, respectively), and the 1.5-, 2-, and 2.33-year peak flows (PK1.5, PK2, and PK2.33, respectively). Q.50 is equivalent to the long-term median streamflow.

\section{Estimates of Monthly and Annual Streamflow Characteristics for Short-Term Gaging Stations}

Five continuous-record gaging stations were installed on five tributaries to the Missouri River that cross CMR (sites 2, $3,4,14$, and 21; table 1 and fig. 1 ). The gaging stations were installed between November 1999 and February 2000 and were operated through September 2004. Procedures used for measuring streamflow and operating the gaging stations are described by Rantz and others (1982).

The 5-year period during which the CMR streams were gaged was characterized by unusually dry conditions. Streamflow records for long-term gaging stations in or near CMR show that, on a regional basis, annual mean streamflows during the study period were among the lowest for any consecutive 5-year period since the start of streamflow-record collection (fig. 3). The very low streamflows that occurred during the study period complicated the use of typical procedures for estimating long-term streamflow characteristics by using short-term streamflow records. During the study period, variability in streamflow was much less than average and for months that typically have low streamflows (that is, September through January), streamflows for the gaged CMR streams generally were extremely low or equal to zero. Some methods for extending streamflow characteristics for short-term gaging stations (for example, the mixed-station procedure described by Alley and Burns, 1983) use correlation between concurrent streamflows of the short-term gaging stations and nearby long-term gaging stations that are hydrologically similar. Use of concurrent-correlation methods were investigated but were found to perform poorly because the small streamflow variability during the study period resulted in poor correlations between streamflows of the short-term gaging stations and those of the long-term gaging stations. Concurrent-correlation methods might have performed acceptably if more typical streamflow conditions had occurred during the study period.

The Regional Adjustment Relationship (RAR; Bakke and others, 1999) provides an alternative to concurrent-correlation methods. The conceptual basis of the RAR is that at individual stream sites the correlation between a streamflow characteristic for a short period of record and long-term streamflow characteristics is consistent over a somewhat broad and climatically homogeneous region. OLS regressions are used to relate a streamflow characteristic for the short-term period to long-term streamflow characteristics for many long-term 


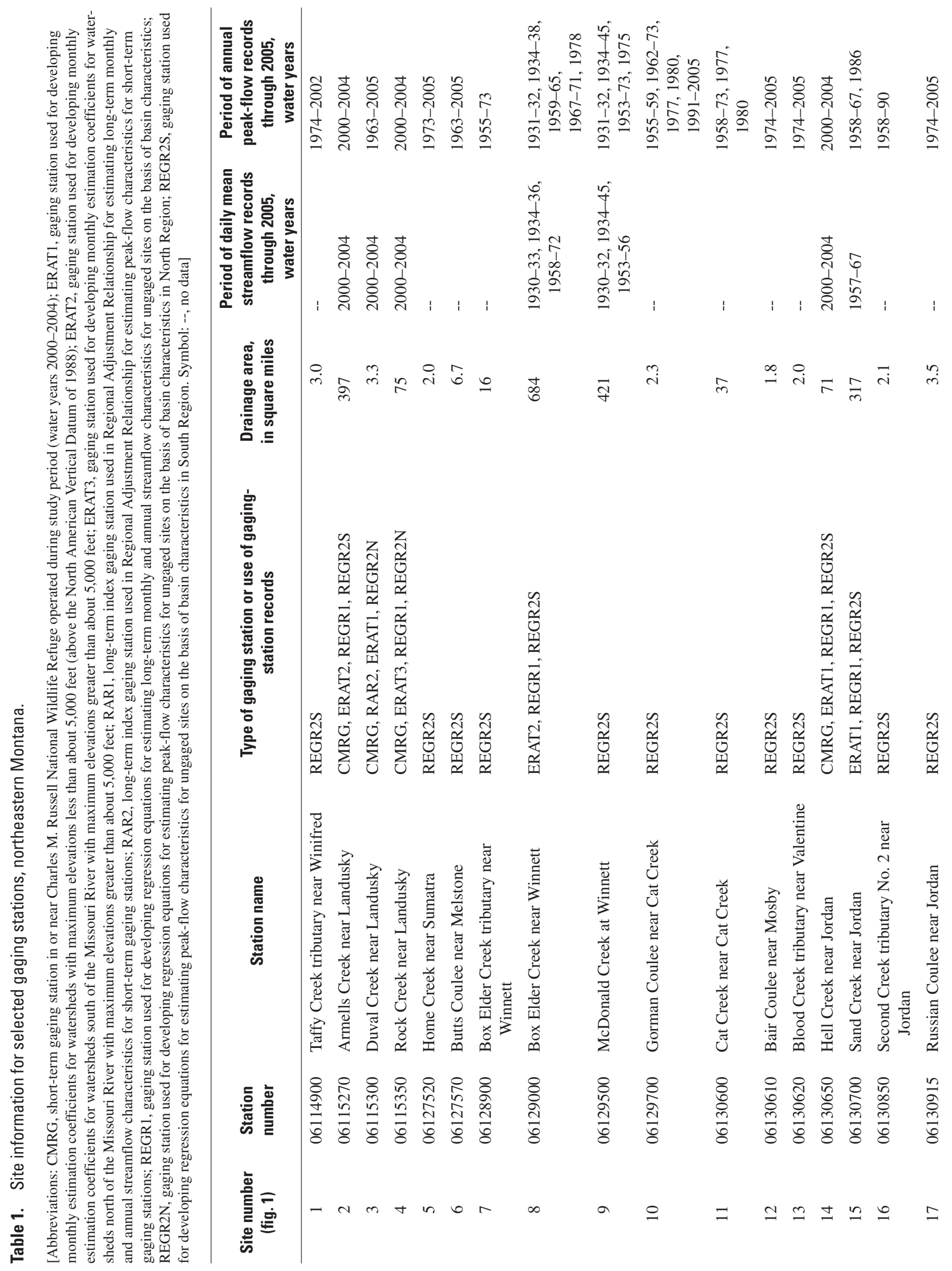



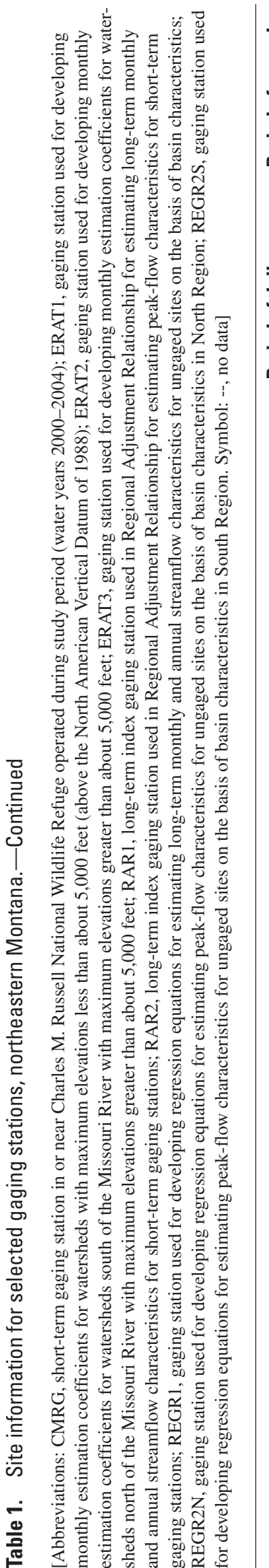

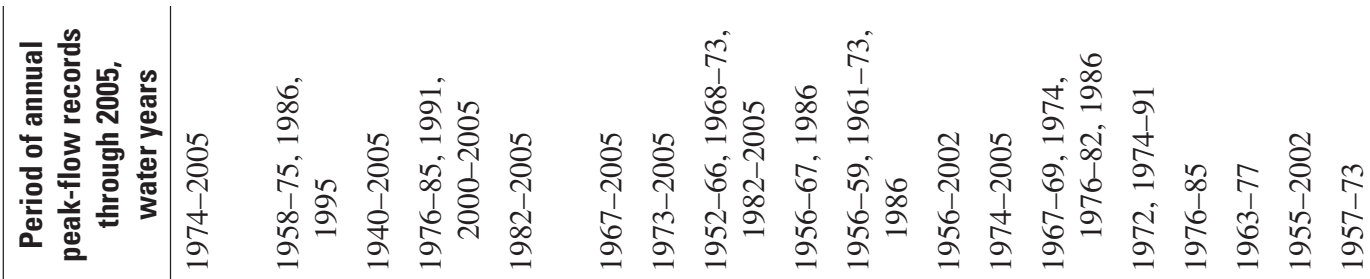

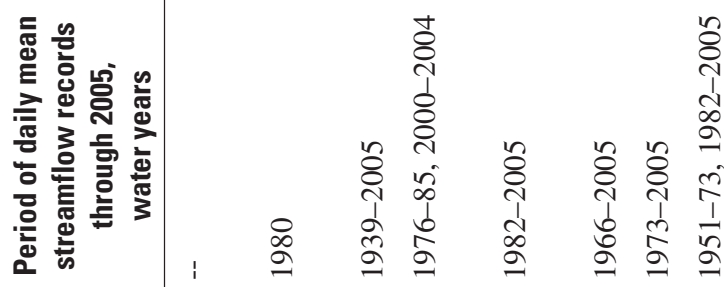

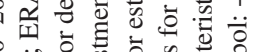

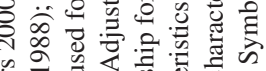

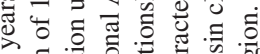

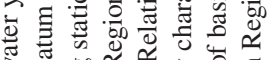

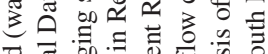

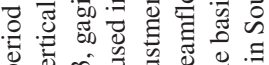

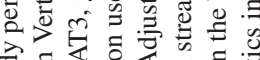

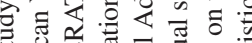

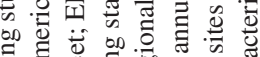

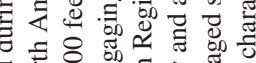

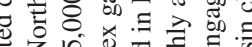

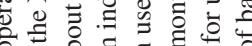

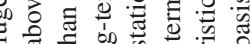

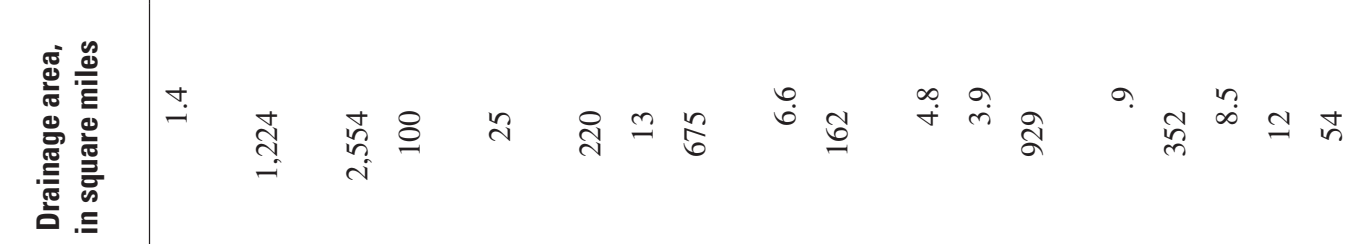

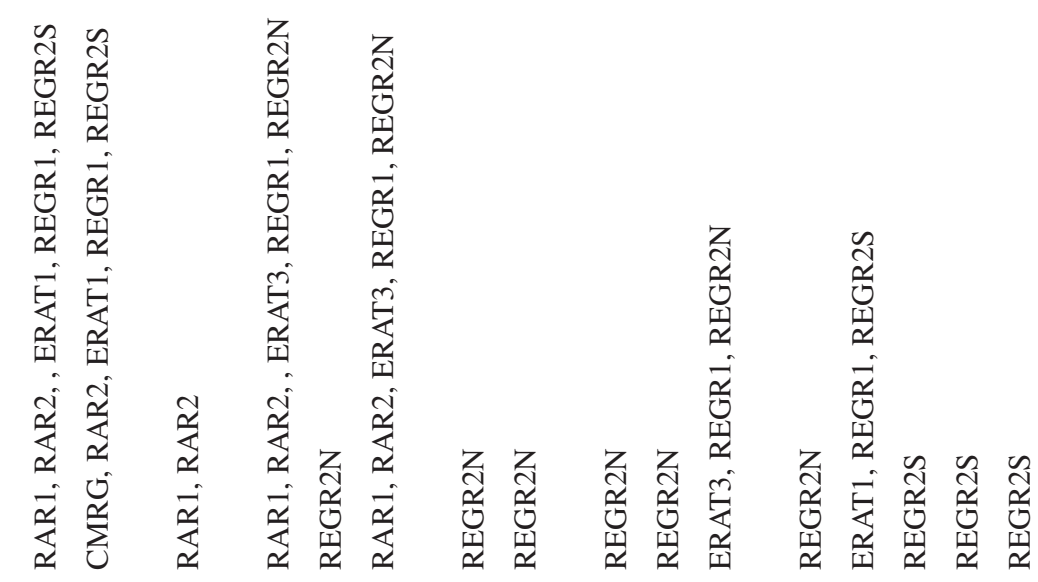

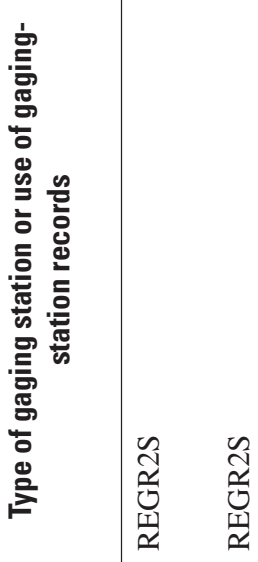

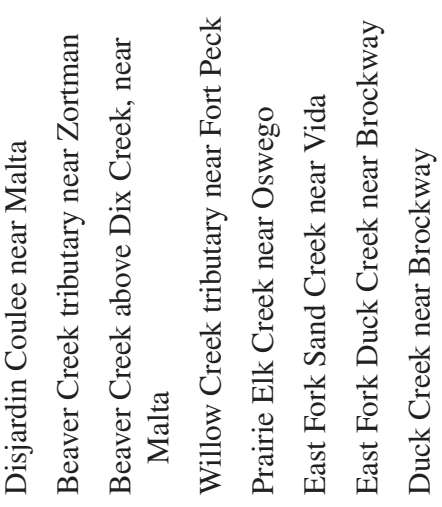

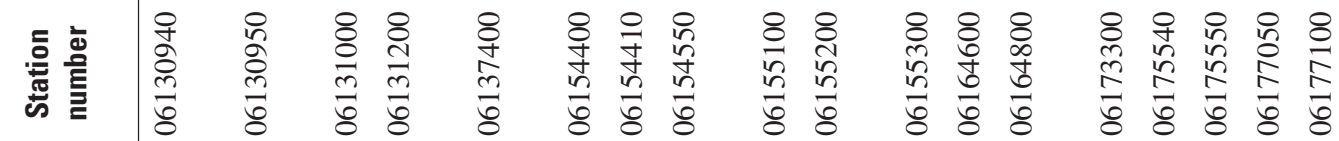

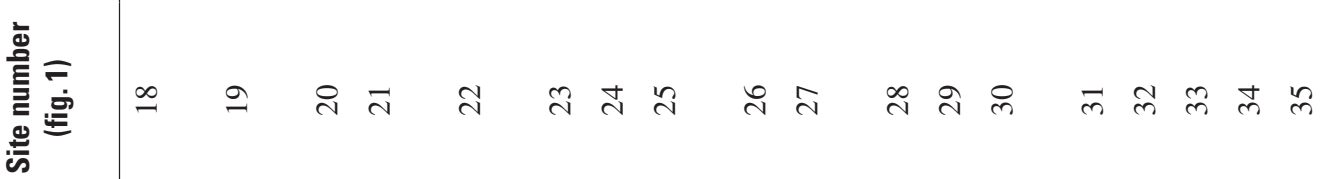




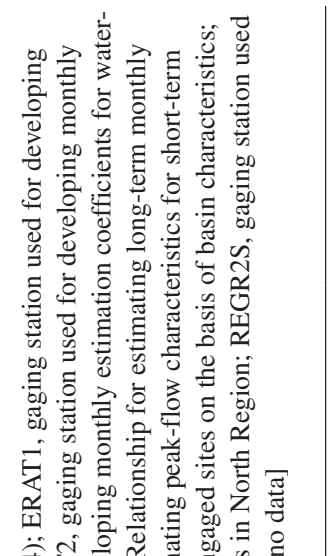

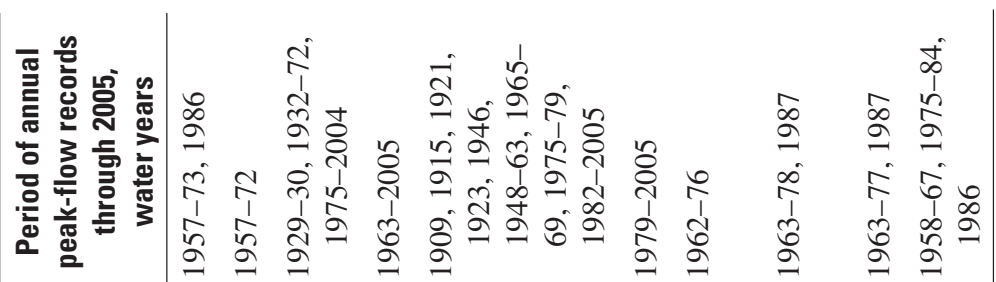

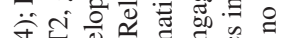

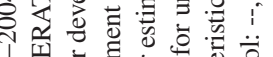

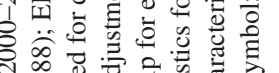

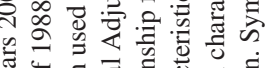

出

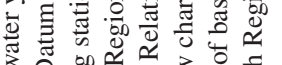

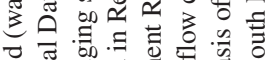

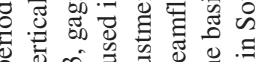

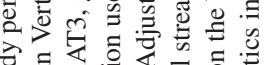

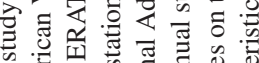

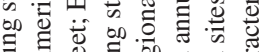

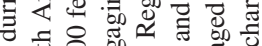

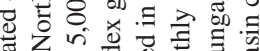

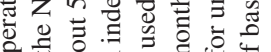

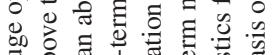

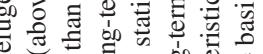

㲅

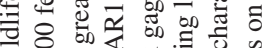

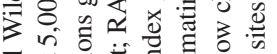

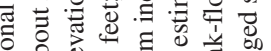

券

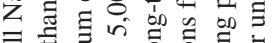

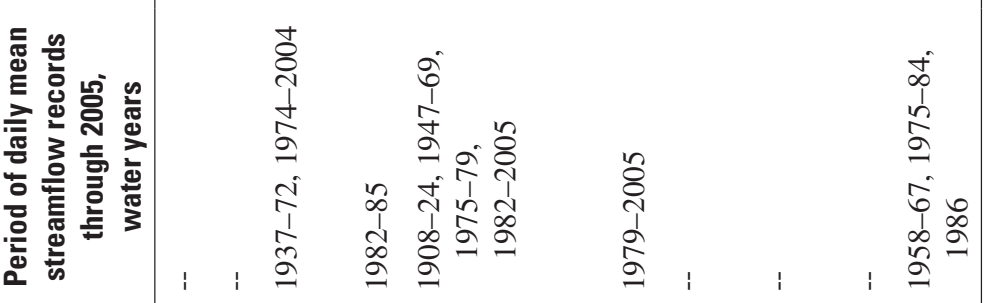

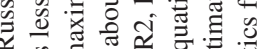

s.

के

䒕记

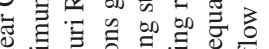

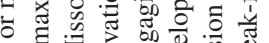

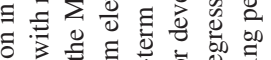

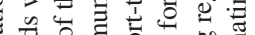

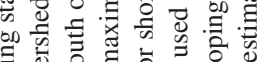

कo

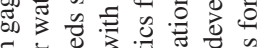

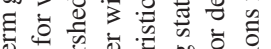

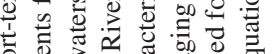

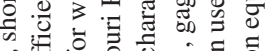

نै

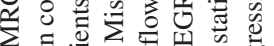

य.

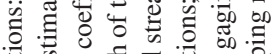

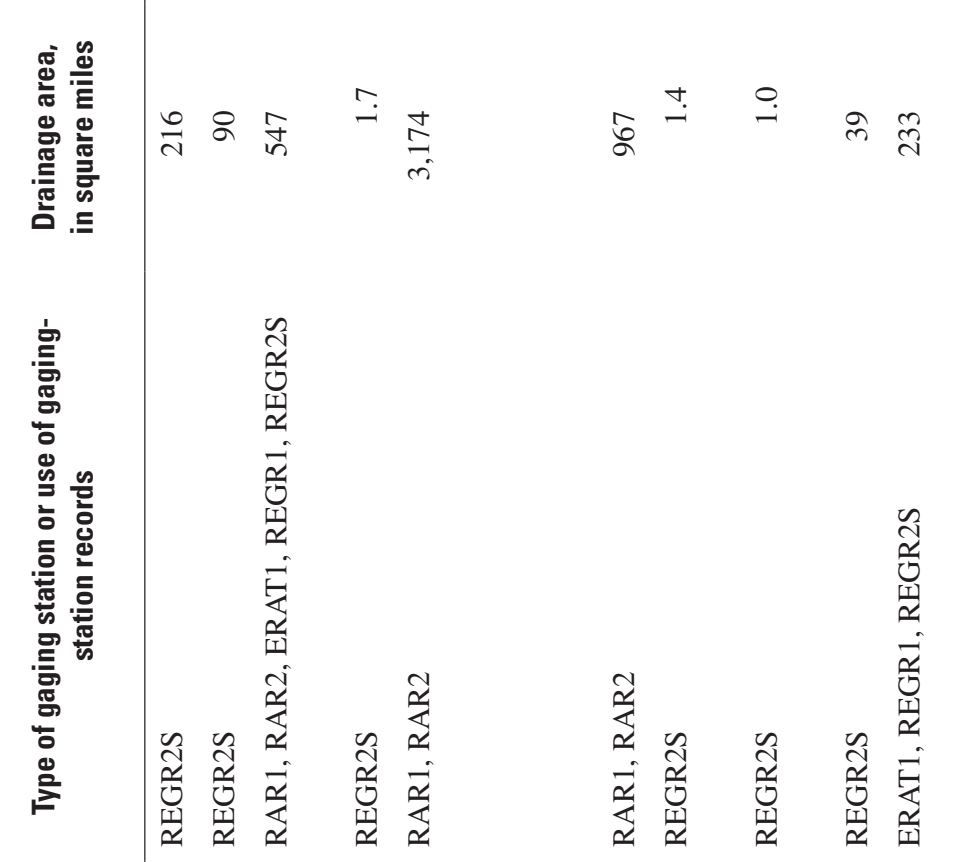

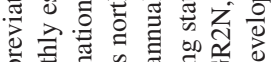

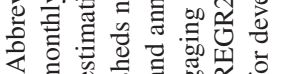

क

ㄴ

$\simeq \simeq$

$\simeq \simeq \simeq \simeq$

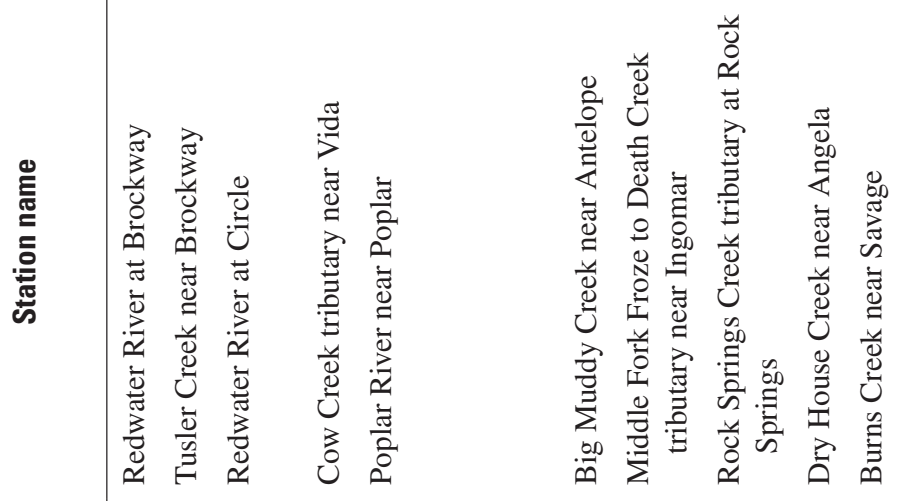

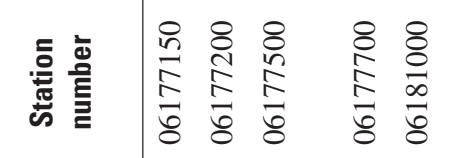

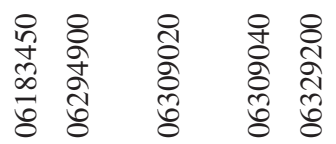

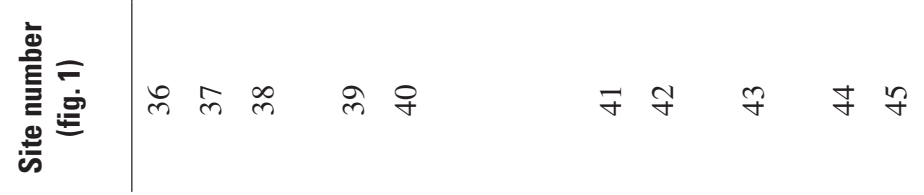




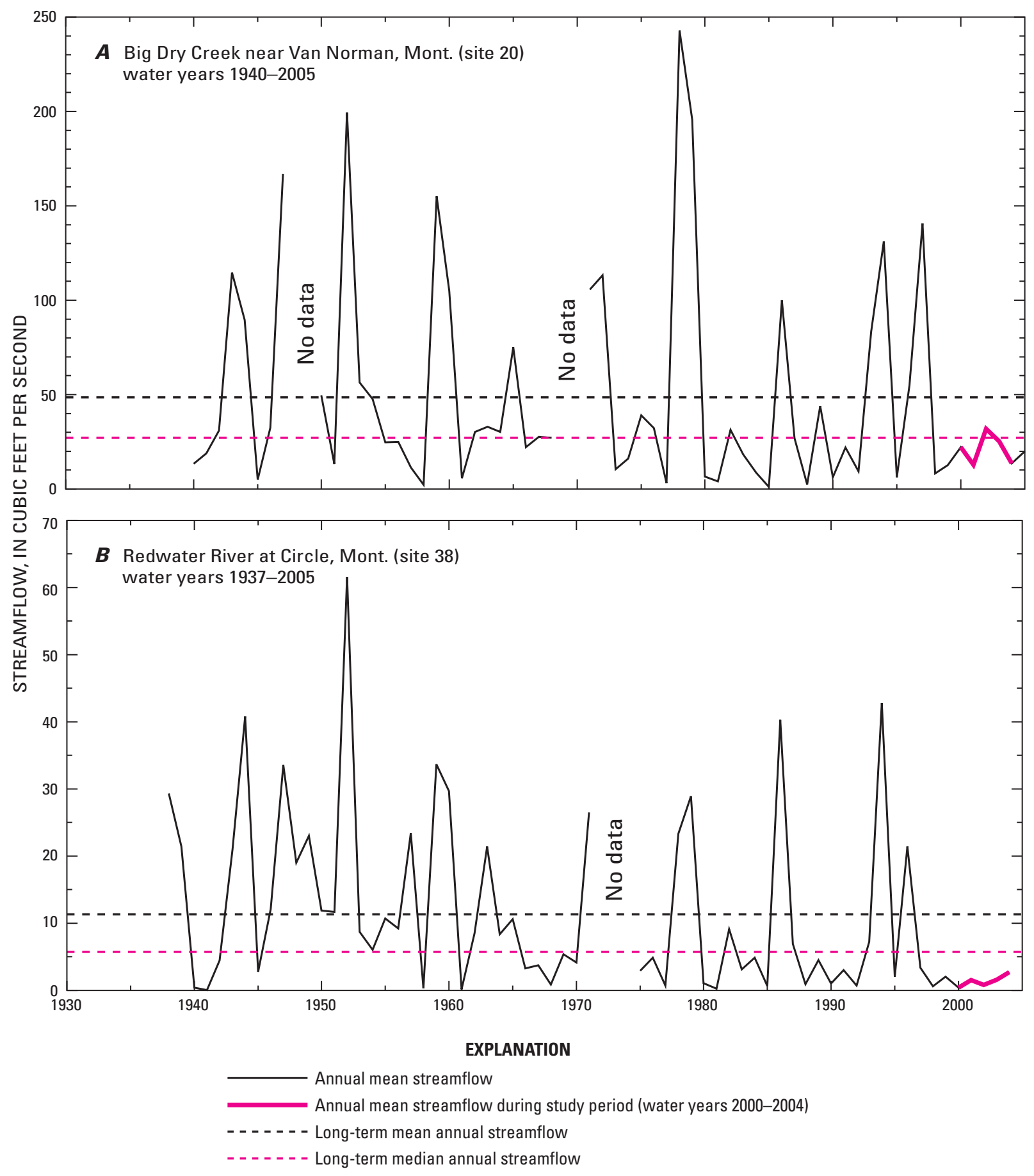

Figure 3. Annual mean streamflow for selected gaging stations. $A$, Big Dry Creek near Van Norman, Mont.; $B$, Redwater River at Circle, Mont. 
index gaging stations (hereinafter referred to as index stations) within the defined region.

Selection of appropriate index stations for estimating regional streamflow relations is critical to application of the RAR. Bakke and others (1999) specify that index stations need to (1) be active during an appropriate long-term period and also active during the short-term period of interest, (2) not be substantially affected by regulation or diversions, (3) not have a substantial number of missing-value or zero-streamflow days, and (4) have a range in drainage areas that span the range of drainage areas for which estimation is needed.

Seven index stations (sites 20, 22, 23, 25, 38, 40, and 41; table 1 and fig. 1) were selected for use in estimating streamflow characteristics for the short-term CMR gaging stations (hereinafter referred to as CMR stations). The selected index stations generally are close to CMR and have more than 20 years of continuous streamflow records. The criteria specified by Bakke and others (1999) for selection of index stations generally were followed with the exception of the requirements that the index stations should not have a substantial number of zero-streamflow days and that the drainage areas span the range of drainage areas for which estimation are needed.

Zero streamflow is not unusual during the low-streamflow months of September through January for all but the largest Missouri River tributaries draining the northeastern plains of Montana. Thus, application of the RAR for lowstreamflow months is not possible if index stations that have a substantial number of zero-streamflow days are excluded. The RAR originally was developed for application in southern Oregon where zero streamflows are uncommon and excluding candidate index stations on the basis of occurrence of zero streamflows would not substantially affect the accuracy of the results. However, excluding index stations on the basis of occurrence of zero streamflows would be inappropriate when applying the RAR to CMR. Inclusion of zero streamflows in the RAR poses problems because streamflow data are transformed to base-10 logarithms prior to performing regression analyses. For this study, any streamflow characteristic that was less than $0.01 \mathrm{ft}^{3} / \mathrm{s}$ was assigned a value of $0.01 \mathrm{ft}^{3} / \mathrm{s}$.

The requirement that the drainage areas of the index stations span the range of drainage areas for which estimation are needed also was not strictly adhered to. Drainage areas for four of the five CMR stations are within the range of drainage areas for the index stations. However, one of the CMR stations (site 3; Duval Creek near Landusky; drainage area of $3.3 \mathrm{mi}^{2}$ ) has a drainage area that is smaller than the range for the index stations ( 25 to $3,174 \mathrm{mi}^{2}$ ). Thus, it was necessary to extrapolate below the range of drainage areas of the index stations to provide estimates of streamflow characteristics for site 3 (table 1 and fig. 1). Therefore, estimates of streamflow characteristics for this gaging station need to be used with caution.

For the CMR stations, the RAR was investigated for estimating the long-term Q.90, Q.80, Q.50, Q.20, and QM on a monthly basis and also on an annual basis. On a monthly basis, the RAR was applied by performing OLS regressions relat- ing the long-term monthly characteristics of the index stations (dependent variables) to the study period mean monthly streamflows of the index stations (explanatory variables) for each streamflow characteristic and each month. All data were transformed to base-10 logarithms prior to analysis. For some months, improved regression results for a given month were obtained by averaging the study period mean monthly streamflows for the given month with those for the previous and/or following month(s). On an annual basis, the RAR was applied by performing OLS regressions relating each of the longterm annual characteristics of the index stations (dependent variables) to the study period mean annual streamflows of the index stations (explanatory variables). Study-period and longterm monthly and annual streamflow characteristics for the index stations used in the RAR are presented in Supplement 1 (at the back of this report).

The RAR regression results were reviewed for outliers, leverage, influence, distribution of residuals (that is, the differences between streamflow characteristics estimated by using regression-equations and streamflow characteristics estimated by using recorded streamflow data), and overall statistical significance (by using methods described by Helsel and Hirsch, 2002, pp. 228-251), and also evaluated for suitability for producing reliable estimates on the basis of the SEE. For some datasets, a regression equation can have a relatively high level of overall significance (that is, a low probability that the linear relation occurred by chance) but may not yield reliable results because of a large SEE. Strict guidelines for determining suitability of regression equations for producing reliable streamflow estimates are not well documented. Previous studies using regression methods for estimating various streamflow characteristics in northeastern Montana have reported values of SEE or SEP ranging from about 31 to 130 percent (Omang and Parrett, 1984; Parrett and others, 1989; Parrett and Johnson, 2003). For this study, the regression equations developed by using the RAR were determined to provide acceptable results when (1) the regression relations were not substantially affected by outliers, high-leverage values, high-influence values or non-normally distributed residuals; (2) the overall statistical significance exceeded about 95 percent (that is, the $\mathrm{p}$-value was less than about 0.05 ); and (3) the SEE was less than about 125 percent. The median SEE for the RAR regression equations was 51.6 percent. Values of SEE ranged from 29.6 to 122.6 percent (table 2).

For the CMR stations, the RAR regression equations were determined to provide acceptable results for estimating the long-term Q.90, Q.80, Q.50, Q.20, and QM on a monthly basis for the months of March through June, and also on an annual basis. For the months of September through January, the RAR regression equations did not provide acceptable results for any long-term streamflow characteristic. For the month of February, the RAR regression equations provided acceptable results for the long-term Q.50 and QM but poor results for the long-term Q.90, Q.80, and Q.20. For the months of July and August, the RAR provided acceptable results for the long-term Q.50, Q.20, and QM but poor results for the 
Table 2. Regression equations used to estimate long-term monthly and annual streamflow characteristics for the short-term gaging stations.

[Equations were developed by using the Regional Adjustment Relationship. Abbreviations: Q.90, 90-percent exceedance streamflow; Q.80, 80-percent exceedance streamflow; Q.50, 50-percent exceedance streamflow; Q.20, 20-percent exceedance streamflow; QM, mean streamflow; RBCF, retransformation bias-correction factor; p-value, significance level; $\mathrm{R}^{2}$, coefficient of determination; SEE, average standard error of estimate (in percent). Symbol: <, less than]

\begin{tabular}{|c|c|c|c|c|c|}
\hline $\begin{array}{l}\text { Long-term } \\
\text { streamflow } \\
\text { characteristic }\end{array}$ & Equation & RBCF & $\mathbf{R}^{2}$ & SEE & p-value \\
\hline February Q.50 & $=3.0 Q M(\text { study period, February })^{0.40}$ & 1.04 & 0.48 & 81.5 & 0.083 \\
\hline February QM & $=4.2$ QM(study period, February/March $)^{0.51}$ & 1.03 & .58 & 72.9 & .047 \\
\hline March Q.90 & $=0.27$ QM(study period, March $)^{0.73}$ & 1.04 & .71 & 85.9 & .018 \\
\hline March Q.80 & $=0.75 Q M(\text { study period, } \text { March })^{0.63}$ & 1.02 & .75 & 62.8 & .012 \\
\hline March Q.50 & $=2.4 Q M(\text { study period, } \text { March })^{0.69}$ & 1.01 & .92 & 33.4 & $<.001$ \\
\hline March Q.20 & $=3.8$ QM $(\text { study period, } \text { March })^{0.93}$ & 1.03 & .85 & 68.3 & .003 \\
\hline March QM & $=3.6 Q M(\text { study period, } \text { March })^{0.86}$ & 1.03 & .83 & 66.5 & .004 \\
\hline April Q.90 & $=0.47$ QM(study period, April/May $)^{1.0}$ & 1.01 & .95 & 41.0 & $<.001$ \\
\hline April Q.80 & $=0.80$ QM $(\text { study period, April/May })^{0.95}$ & 1.01 & .97 & 29.6 & $<.001$ \\
\hline April Q.50 & $=2.9$ QM(study period, April/May $)^{0.85}$ & 1.01 & .94 & 40.8 & $<.001$ \\
\hline April Q.20 & $=2.8 Q M(\text { study period, March/April/May })^{0.97}$ & 1.03 & .83 & 74.7 & .004 \\
\hline April QM & $=2.8$ QM $(\text { study period }, \text { March/April/May })^{1.0}$ & 1.01 & .94 & 39.0 & $<.001$ \\
\hline May Q.90 & $=0.28 Q M(\text { study period, May })^{1.0}$ & 1.03 & .85 & 88.9 & .003 \\
\hline May Q.80 & $=0.78$ QM(study period, May $)^{0.86}$ & 1.01 & .95 & 37.3 & $<.001$ \\
\hline May Q.50 & $=2.5 Q M(\text { study period, May })^{0.73}$ & 1.01 & .95 & 31.7 & $<.001$ \\
\hline May Q.20 & $=8.0 Q M(\text { study period, May })^{0.64}$ & 1.01 & .89 & 41.1 & .001 \\
\hline May QM & $=7.8$ QM(study period, May $)^{0.58}$ & 1.02 & .77 & 63.7 & .010 \\
\hline June Q.90 & $=0.24$ QM(study period, May/June $)^{0.77}$ & 1.03 & .83 & 74.3 & .004 \\
\hline June Q.80 & $=0.52$ QM(study period, May/June $)^{0.69}$ & 1.03 & .79 & 78.1 & .008 \\
\hline June Q.50 & $=3.1$ QM(study period, May/June $)^{0.56}$ & 1.02 & .80 & 57.3 & .007 \\
\hline June Q.20 & $=21$ QM(study period, May/June $)^{0.33}$ & 1.01 & .69 & 44.6 & .021 \\
\hline June QM & $=14$ QM(study period, May/June $)^{0.31}$ & 1.02 & .60 & 51.6 & .040 \\
\hline July Q.50 & $=0.75$ QM(study period, June/July $)^{0.86}$ & 1.04 & .81 & 95.3 & .006 \\
\hline July Q.20 & $=9.5$ QM(study period, June $/ J u l y)^{0.47}$ & 1.01 & .83 & 41.4 & .004 \\
\hline July QM & $=7.7$ QM(study period, June/July $)^{0.43}$ & 1.01 & .88 & 31.0 & .002 \\
\hline August Q.50 & $=0.93$ QM $(\text { study period, August/September })^{1.0}$ & 1.06 & .84 & 122.6 & .004 \\
\hline August Q.20 & $=5.5 \mathrm{QM}(\text { study period, August/September })^{0.51}$ & 1.02 & .82 & 54.6 & .005 \\
\hline August QM & $=5.4 Q M(\text { study period, August/September })^{0.46}$ & 1.01 & .83 & 48.0 & .005 \\
\hline Annual Q.90 & $=0.55$ QM(study period, annual $)^{0.90}$ & 1.01 & .90 & 49.0 & .001 \\
\hline Annual Q.80 & $=1.0 Q M(\text { study period, annual })^{0.82}$ & 1.01 & .93 & 34.5 & $<.001$ \\
\hline Annual Q.50 & $=3.2 Q M(\text { study period, annual })^{0.71}$ & 1.01 & .93 & 31.0 & $<.001$ \\
\hline Annual Q.20 & $=11 Q M(\text { study period, annual })^{0.61}$ & 1.02 & .74 & 60.3 & .013 \\
\hline Annual QM & $=6.1 Q M(\text { study period, annual })^{0.64}$ & 1.01 & .85 & 43.3 & .003 \\
\hline
\end{tabular}


long-term Q.90 and Q.80. RAR regression equations for longterm streamflow characteristics that had acceptable results are presented in table 2 . Use of regression analysis on log-transformed data has been shown to result in systematic bias when the results are retransformed from log units to the original arithmetic units (Koch and Smillie, 1986). To compensate for this bias, retransformed results were multiplied by a nonparametric retransformation bias-correction factor (Duan, 1983) that is shown in table 2. Example plots that illustrate the regression relations used for estimating long-term annual 50-percent exceedance (median) and mean annual streamflows are presented in figure 4.

Estimation coefficients were developed for estimating the long-term streamflow characteristics for the CMR stations for the months that the RAR did not provide acceptable results. These coefficients were developed by using continuous streamflow records from streams in the study area or in nearby watersheds that generally are hydrologically similar to the streams that cross CMR. The estimation coefficients were determined by calculating the ratio of a given streamflow characteristic to the mean annual streamflow. Estimation coefficients were developed for three types of watersheds: (1) watersheds with maximum elevations less than about 5,000 ft (above NAVD 88); (2) watersheds on the south side of the Missouri River with maximum elevations greater than about 5,000 ft; and (3) watersheds on the north side of the Missouri River with maximum elevations greater than about $5,000 \mathrm{ft}$. Streamflow data for selected gaging stations (indicated in table 1 and fig. 1) in watersheds that met the criteria for each watershed type were analyzed to determine the ratio of each streamflow characteristic to the mean annual streamflow for each selected gaging station. Estimation coefficients for each watershed type and each streamflow characteristic (table 3) were calculated by determining the weighted average (weighting based on number of years of record) of the ratios of all the selected gaging stations for a given watershed type. Although the estimation coefficients were used only to estimate long-term streamflow characteristics for months that the RAR did not provide acceptable results, estimation coefficients for all streamflow characteristics and all months are presented in table 3 for informational purposes.

Actual study-period monthly and annual streamflow characteristics (calculated by using recorded data) and estimated long-term monthly and annual streamflow characteristics (determined by using the RAR and estimation coefficients) for the CMR stations are presented in table 4. Example plots showing the actual study period and the estimated long-term median and mean monthly streamflows for the CMR stations are presented in figure 5. Example plots showing the actual study period and the actual long-term median and mean monthly streamflows for selected index stations are presented in figure 6 . The relations between the actual study period and estimated long-term streamflow characteristics for the CMR stations (fig. 5) generally are similar to the relations between the actual study period and actual long-term streamflow characteristics for the index stations (fig. 6). Streams in the northeastern plains of Montana generally are characterized by higher streamflows during February through August and lower streamflows during September through January. For most of the index stations, March and April, when most snowmelt runoff typically occurs in northeastern Montana, have the highest mean monthly streamflow. Spring rainstorms also contribute to higher streamflows in March and April. Mean monthly streamflow for February typically is larger than late fall and early winter streamflows, indicating that during some years snowmelt begins in February. Some of the index stations show a mid-spring (about April or May) decrease in streamflow following completion of snowmelt at lower elevations. Late spring and summer rainstorms can increase streamflow during the months of June and July. Streamflows then generally decrease from August through the fall. The estimated long-term streamflow characteristics for the CMR stations generally indicate similar annual streamflow patterns to those of the index stations. 

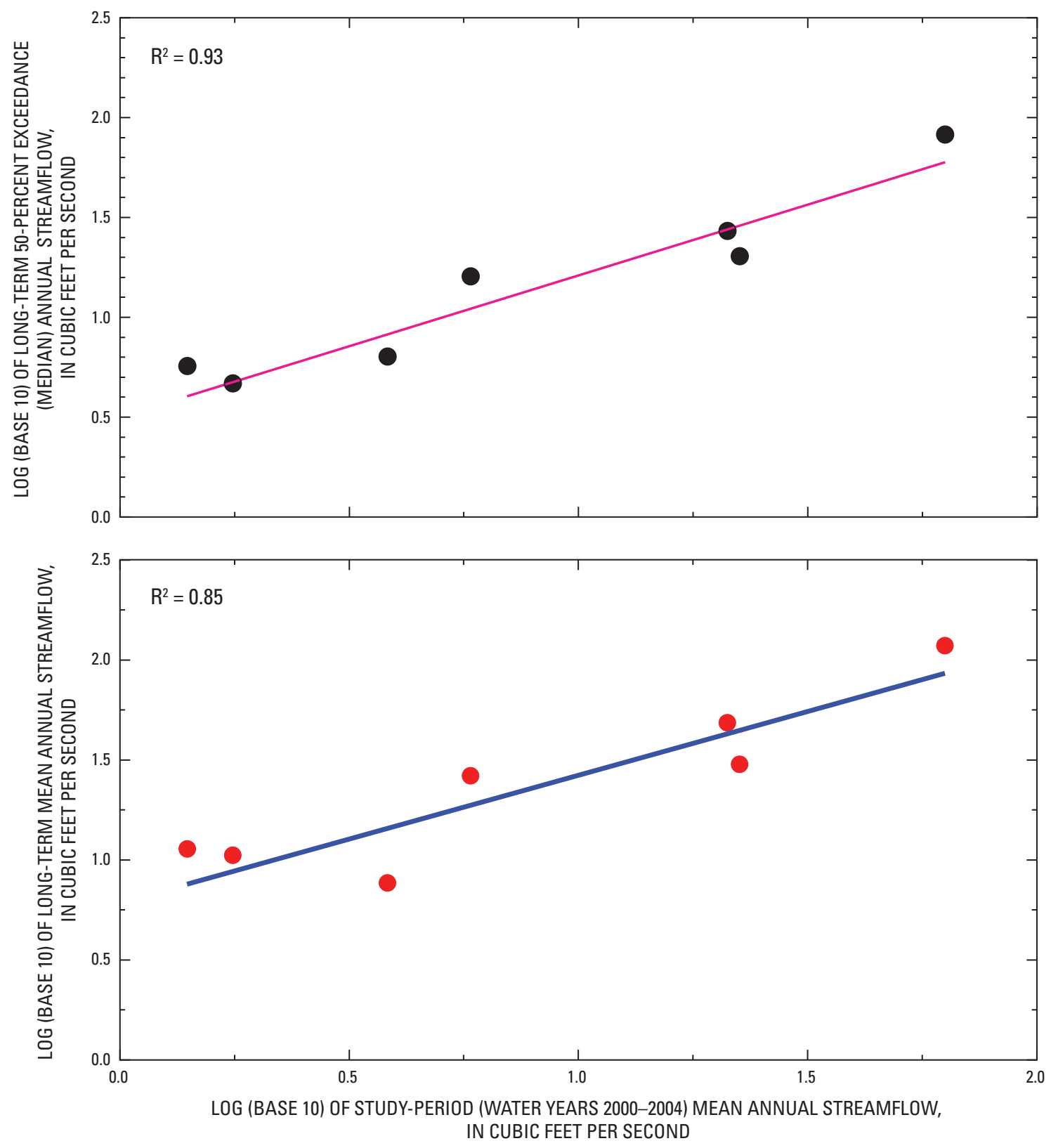

EXPLANATION

Long-term 50-percent exceedance (median) annual streamflow relative to study period (water years 2000-2004) mean annual streamflow for a given long-term index gaging station

- Long-term mean annual streamflow relative to study period (water years 2000-2004) mean annual streamflow for a given long-term index gaging station

Ordinary least squares regression line for long-term 50 -percent exceedance (median) annual streamflow

Ordinary least squares regression line for long-term mean annual streamflow

Figure 4. Regional Adjustment Relationship regression relations used to estimate the long-term 50-percent exceedance (median) and mean annual streamflows for the short-term gaging stations. 


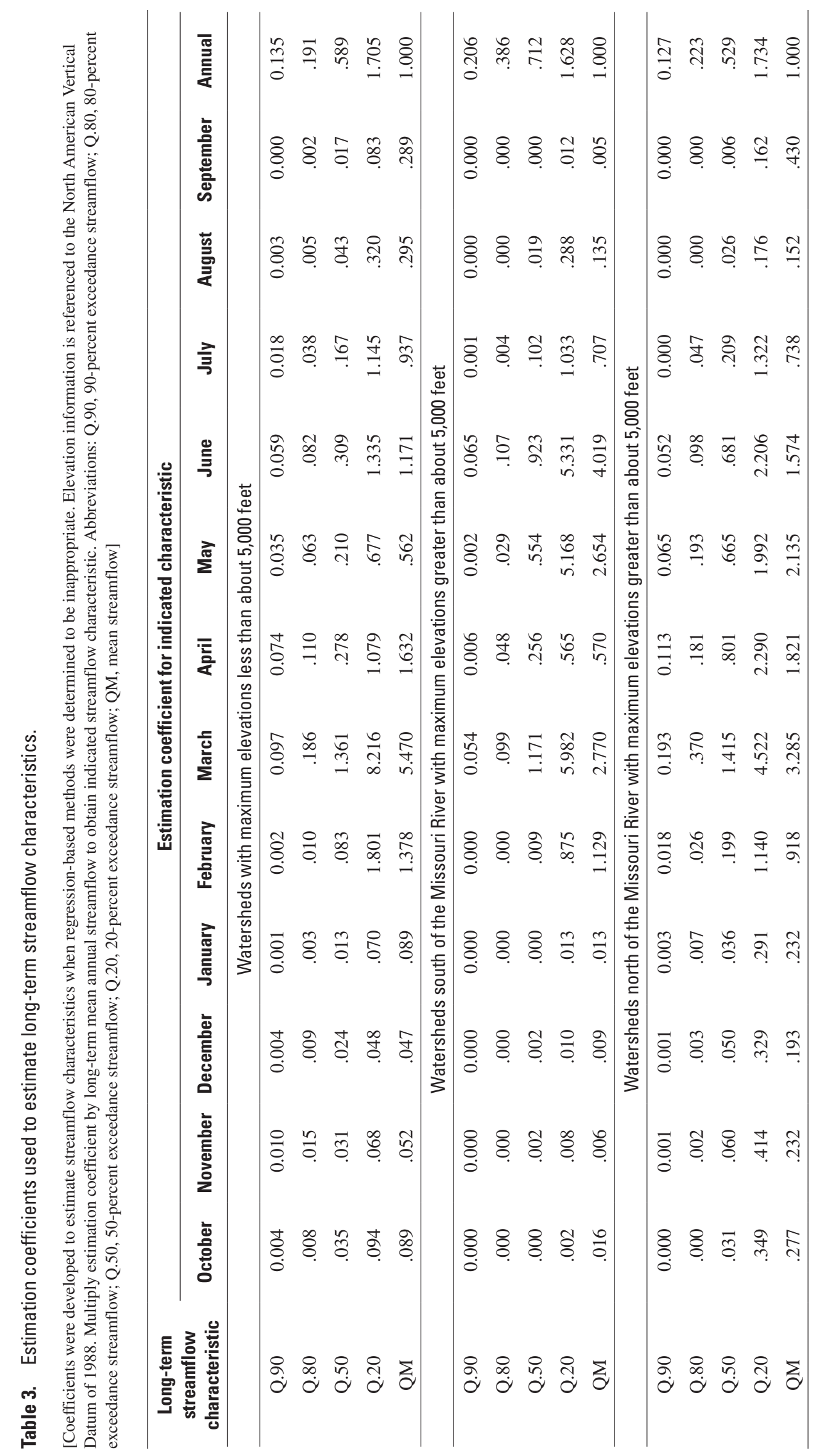




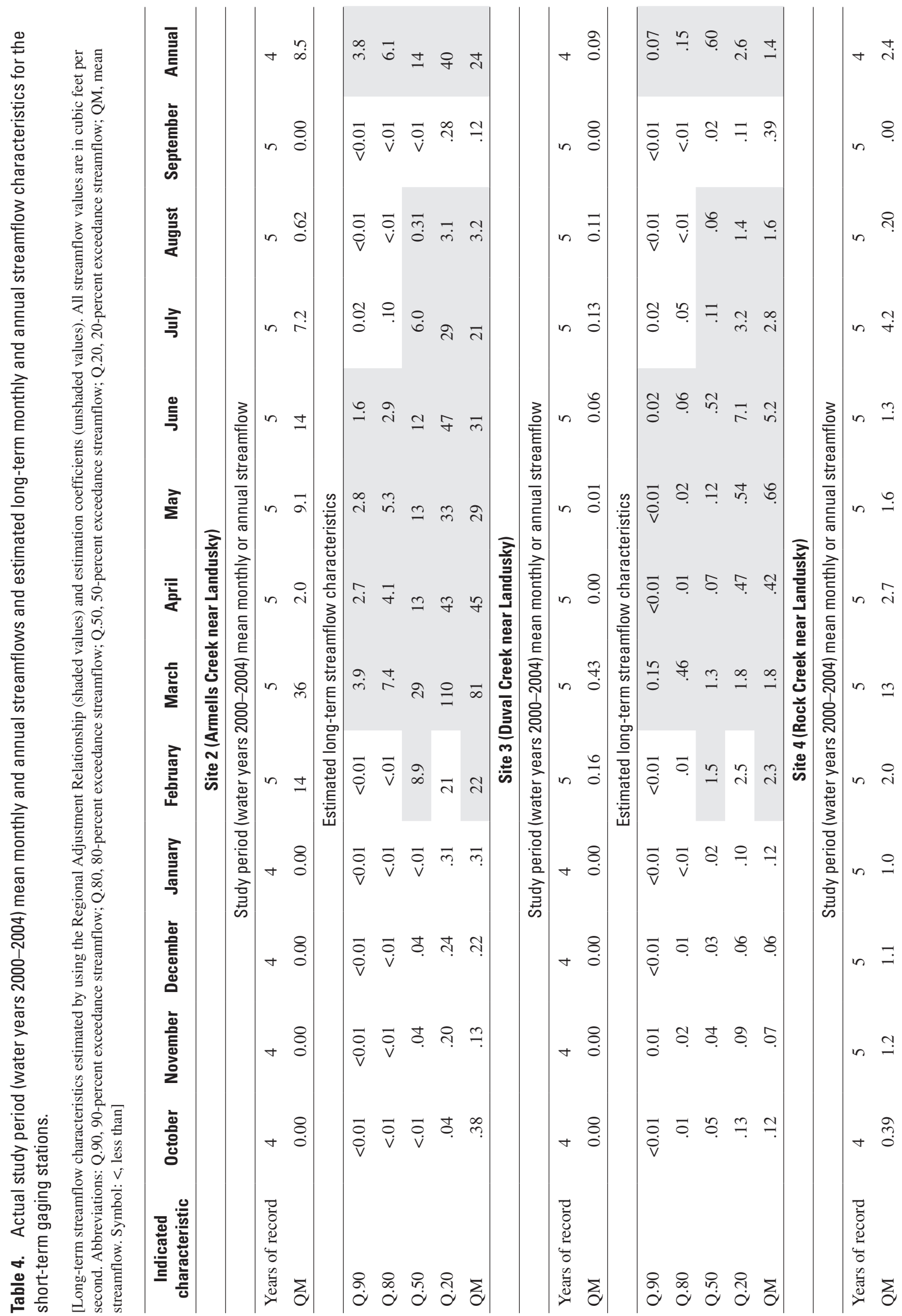




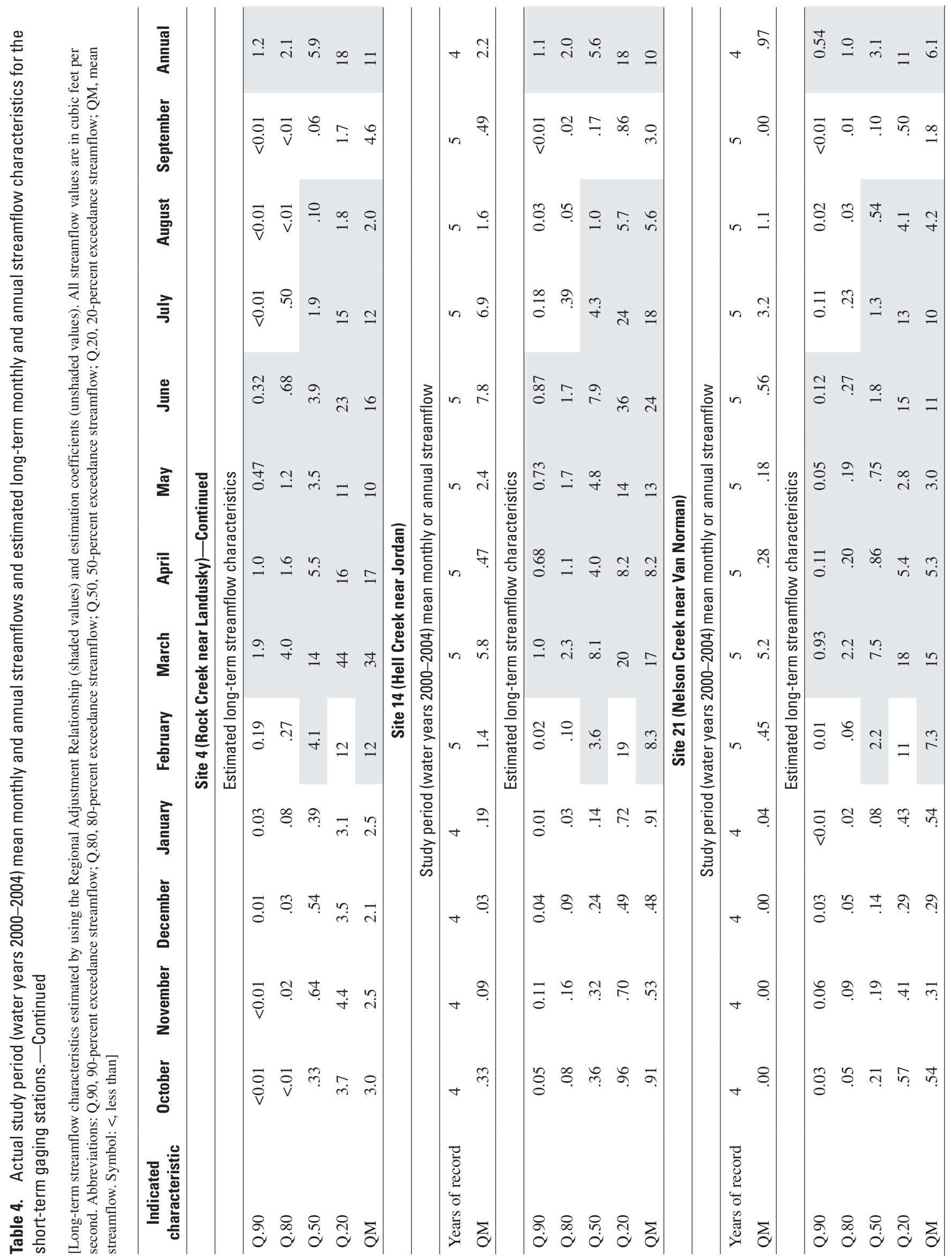




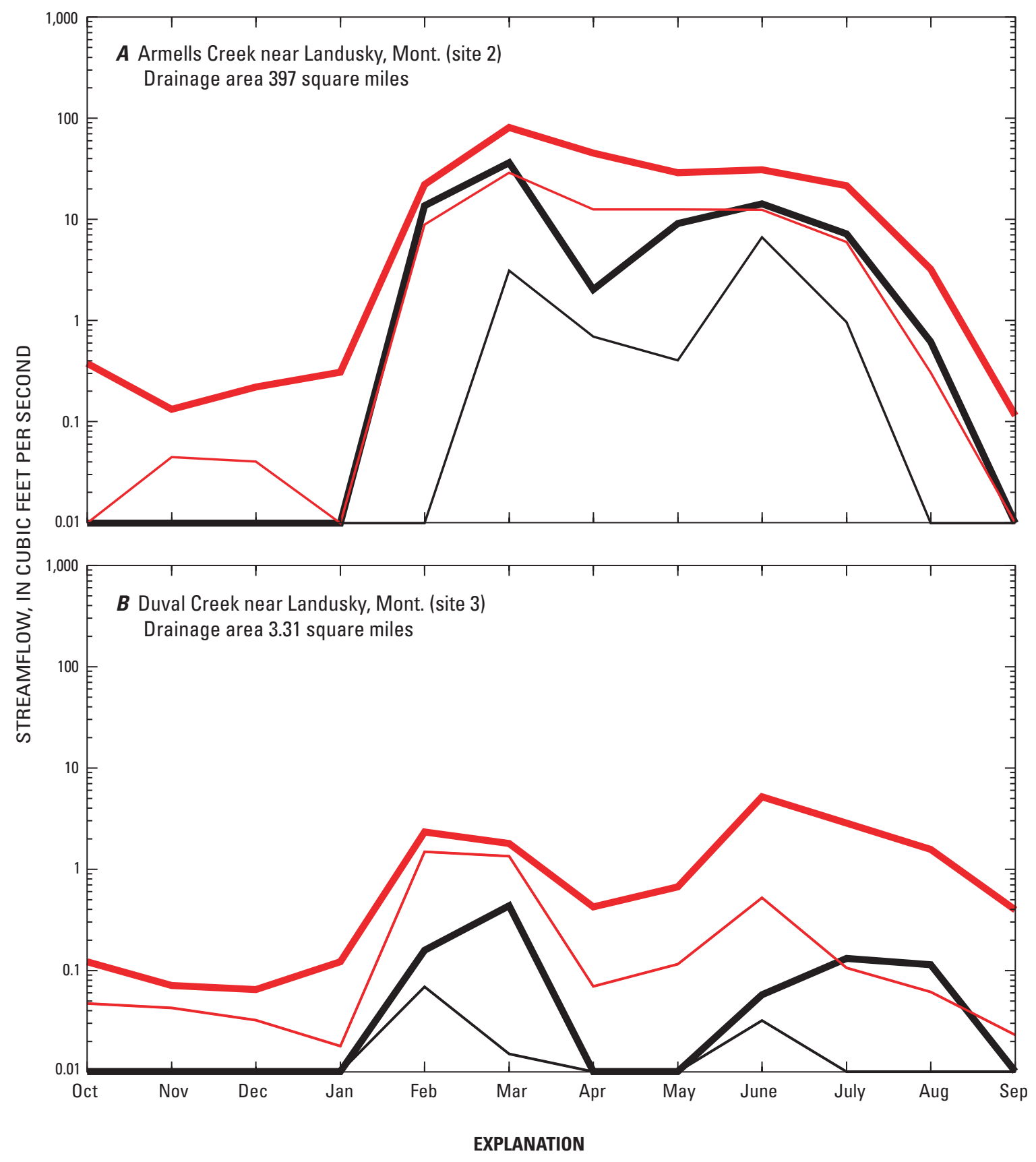

Actual study period (water years 2000-2004) streamflow characteristics (calculated by using recorded data)

50-percent exceedance (median) monthly streamflow

Mean monthly streamflow

Estimated long-term streamflow characteristics (derived by using Regional Adjustment Relationship and estimation coefficients)

50-percent exceedance (median) monthly streamflow

Mean monthly streamflow

Figure 5. Comparison of actual study period (water years 2000-2004) and estimated long-term selected monthly streamflow characteristics for the short-term gaging stations. A, Armells Creek near Landusky, Mont.; $B$, Duval Creek near Landusky, Mont.; $C$, Rock Creek near Landusky, Mont.; $D$, Hell Creek near Jordan, Mont.; $E$, Nelson Creek near Van Norman, Mont. 


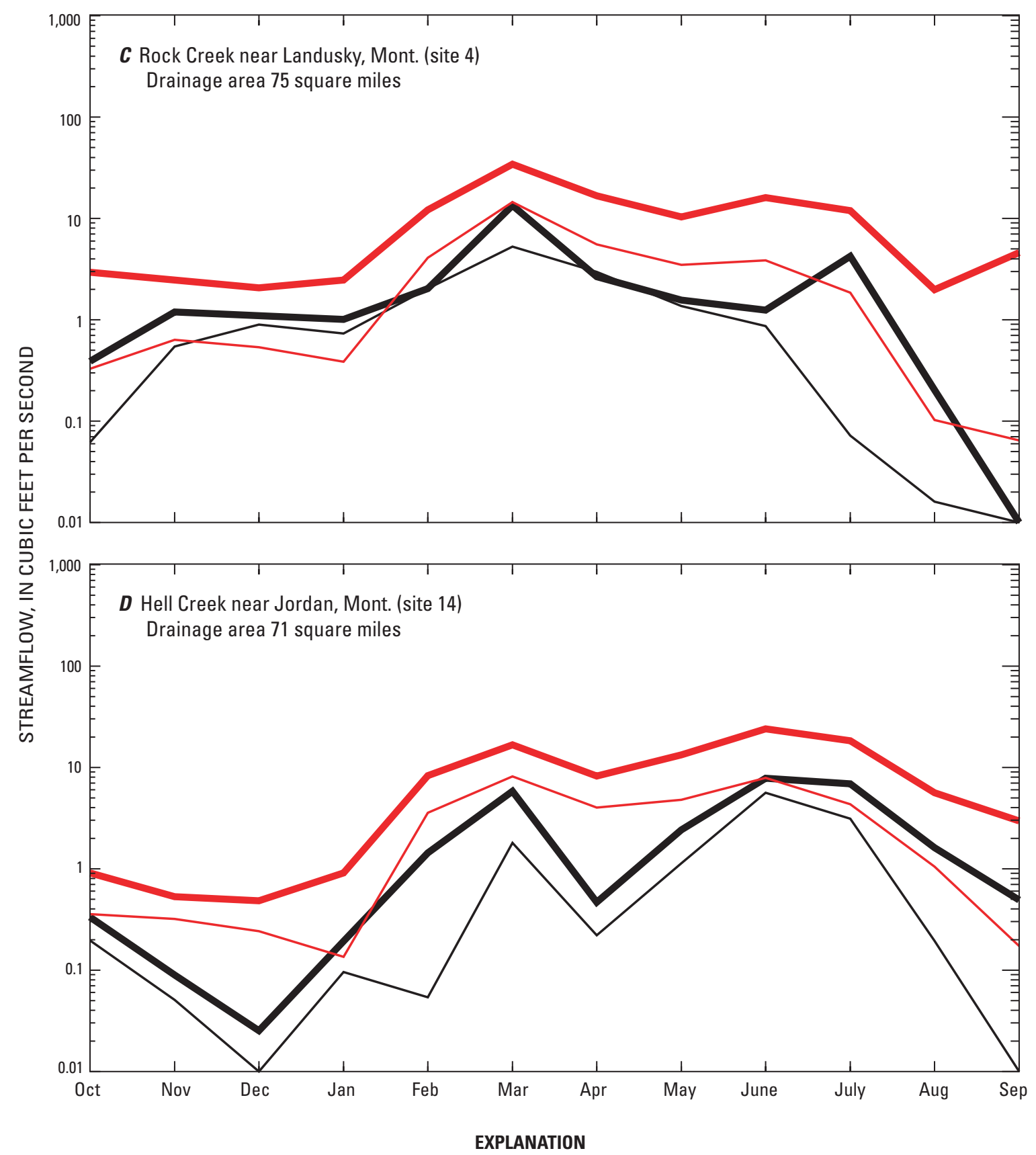

Actual study period (water years 2000-2004) streamflow characteristics (calculated by using recorded data)

50-percent exceedance (median) monthly streamflow

Mean monthly streamflow

Estimated long-term streamflow characteristics (derived by using Regional Adjustment Relationship and estimation coefficients)

50-percent exceedance (median) monthly streamflow

Mean monthly streamflow

Figure 5. Comparison of actual study period (water years 2000-2004) and estimated long-term selected monthly streamflow characteristics for the short-term gaging stations. A, Armells Creek near Landusky, Mont.; $B$, Duval Creek near Landusky, Mont.; $C$, Rock Creek near Landusky, Mont.; $D$, Hell Creek near Jordan, Mont.; $E$, Nelson Creek near Van Norman, Mont.-Continued 


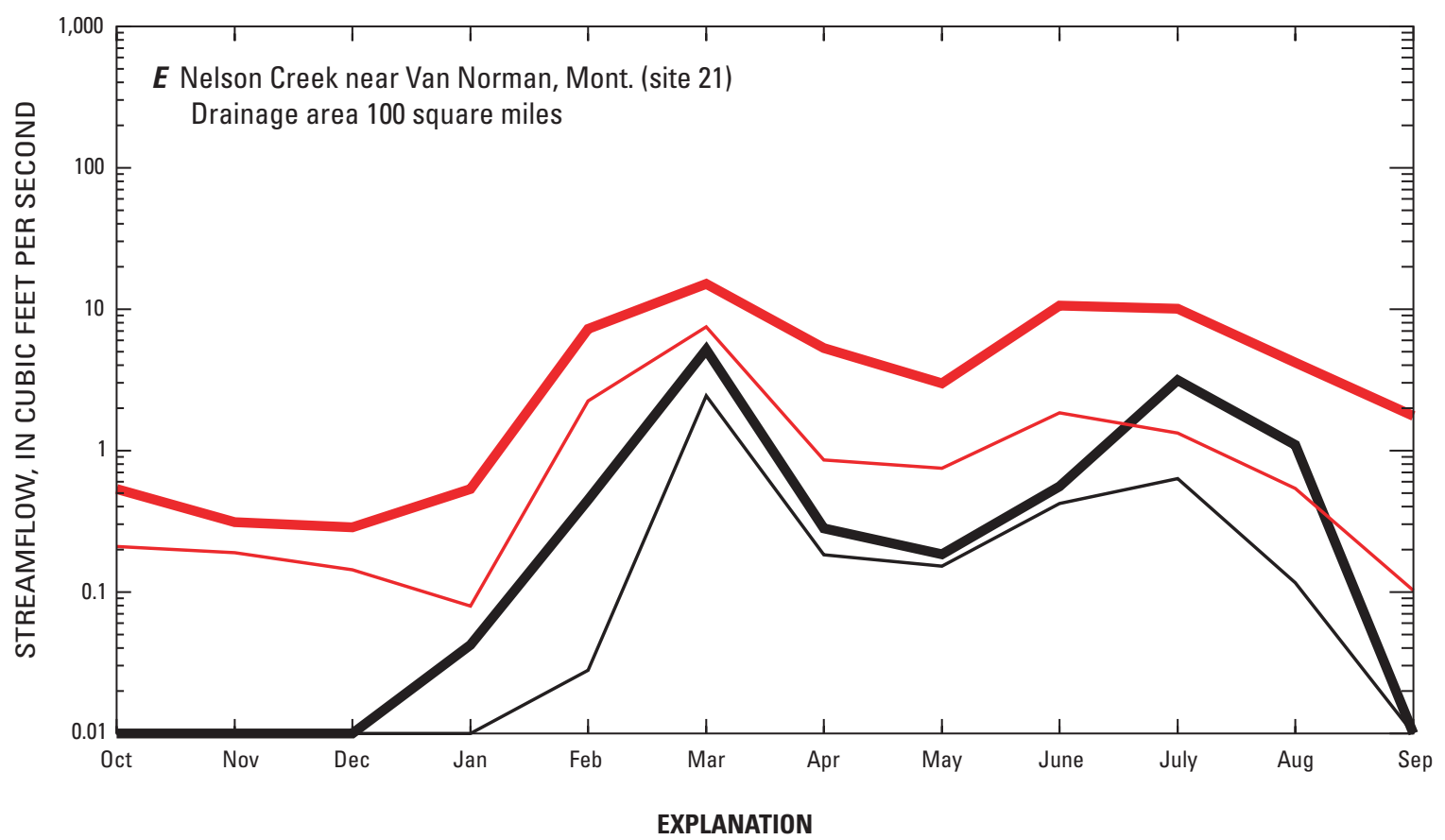

Actual study period (water years 2000-2004) streamflow characteristics (calculated by using recorded data)

50-percent exceedance (m
Mean monthly streamflow

Estimated long-term streamflow characteristics (derived by using Regional Adjustment Relationship and estimation coefficients)

50-percent exceedance (median) monthly streamflow

Mean monthly streamflow

Figure 5. Comparison of actual study period (water years 2000-2004) and estimated long-term selected monthly streamflow characteristics for the short-term gaging stations. A, Armells Creek near Landusky, Mont.; $B$, Duval Creek near Landusky, Mont.; $C$, Rock Creek near Landusky, Mont.; $D$, Hell Creek near Jordan, Mont.; $E$, Nelson Creek near Van Norman, Mont.-Continued 


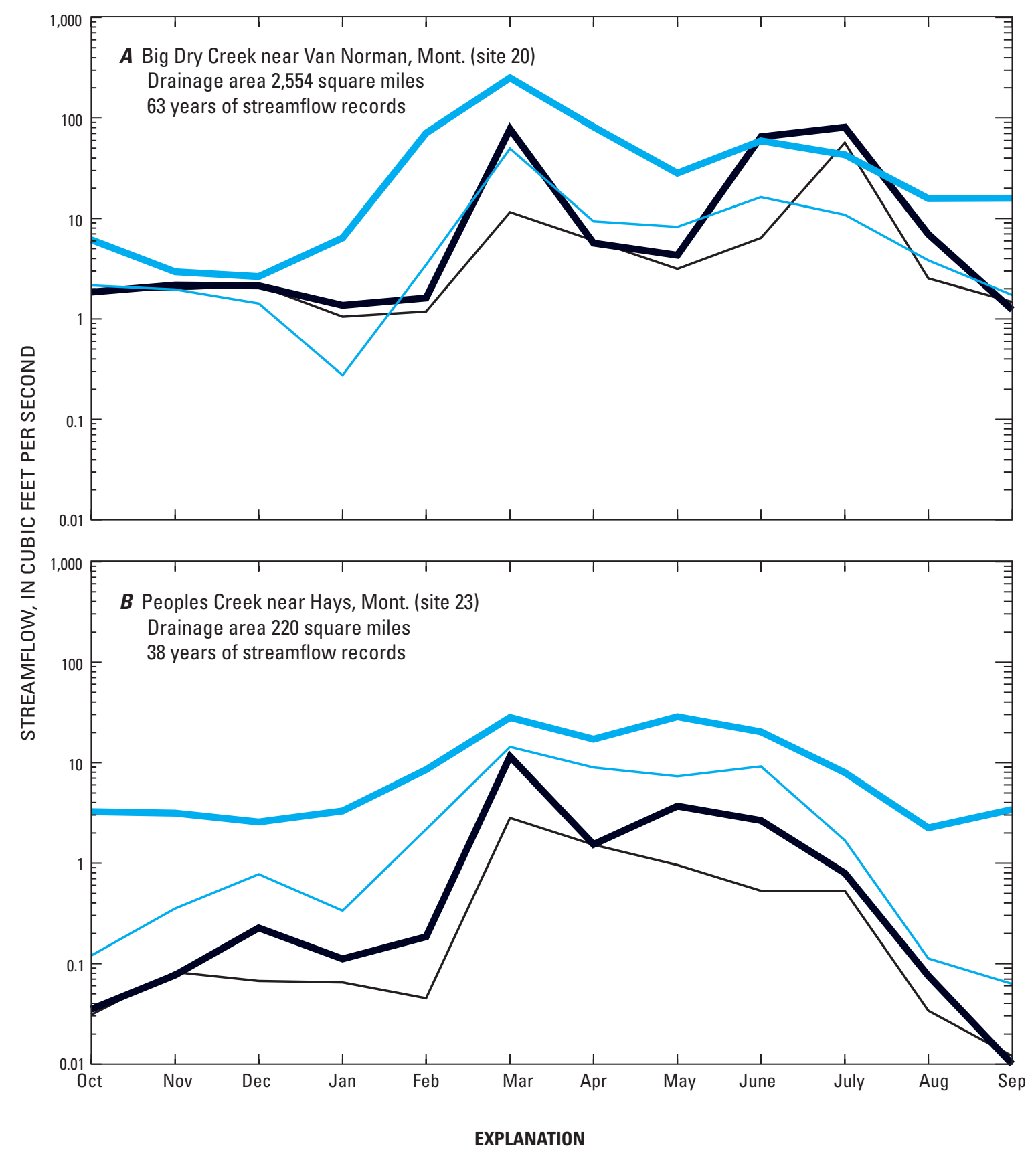

Actual study period (water years 2000-2004) streamflow characteristics (calculated by using recorded data)

50-percent exceedance (median) monthly streamflow

Mean monthly streamflow

Actual long-term streamflow characteristics (calculated by using recorded data)

50-percent exceedance (median) monthly streamflow

Mean monthly streamflow

Figure 6. Comparison of actual study period (water years 2000-2004) and actual long-term selected monthly streamflow characteristics for selected long-term index gaging stations used in the Regional Adjustment Relationship. A, Big Dry Creek near Van Norman, Mont.; B, Peoples Creek near Hays, Mont.; C, Peoples Creek below Kuhr Coulee, near Dodson, Mont.; $D$, Redwater River at Circle, Mont. 


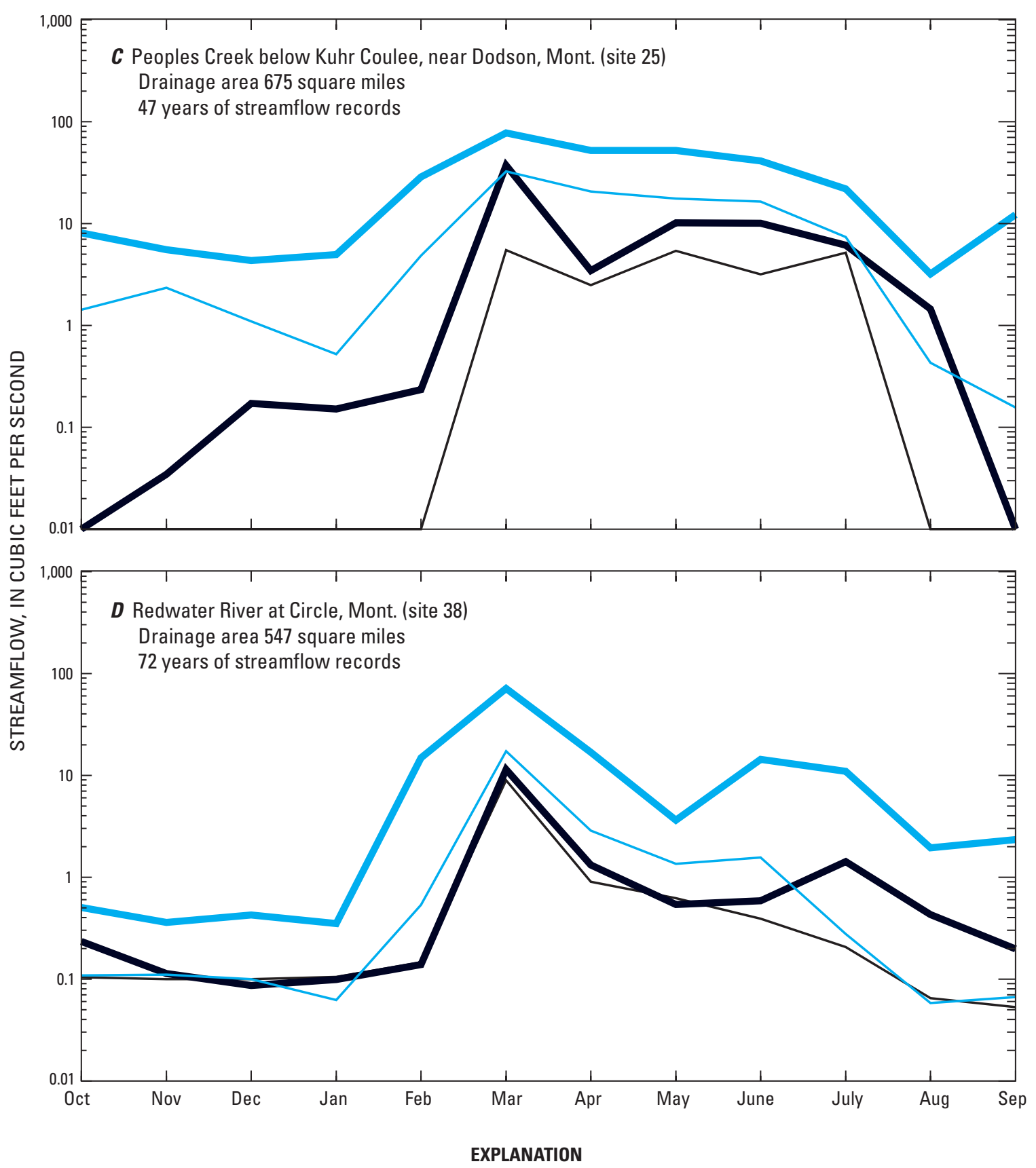

Actual study period (water years 2000-2004) streamflow characteristics (calculated by using recorded data)

- 50-percent exceedance (median) monthly streamflow

Mean monthly streamflow

Actual long-term streamflow characteristics (calculated by using recorded data)

50-percent exceedance (median) monthly streamflow

Mean monthly streamflow

Figure 6. Comparison of actual study period (water years 2000-2004) and actual long-term selected monthly streamflow characteristics for selected long-term index gaging stations used in the Regional Adjustment Relationship. A, Big Dry Creek near Van Norman, Mont.; B, Peoples Creek near Hays, Mont.; C, Peoples Creek below Kuhr Coulee, near Dodson, Mont.; $D$, Redwater River at Circle, Mont.-Continued 


\section{Estimates of $T$-Year Peak Flows for Short-Term Gaging Stations}

The RAR also was investigated for estimating the longterm 1.5-, 2-, and 2.33-year peak flows (PK1.5, PK2, and PK2.33, respectively) for three of the CMR stations (sites 2, 4, and 14; table 1 and fig. 1). Two of the CMR stations (sites 3 and 21; table 1 and fig. 1) had suitable peak-flow records (43 and 17 years, respectively) for determining $T$-year peak-flow characteristics directly and could serve as index stations. Thus, nine index stations (table 1) were used to represent regional study period and long-term peak-flow relations. Study-period mean peak flow (PKM) and long-term PK1.5, PK2, and PK2.33 for the index stations used in the RAR are presented in Supplement 2 (at the back of this report). The PK1.5, PK2, and PK2.33 were determined by using procedures described in Bulletin 17B, "Guidelines for Determining Flood Flow Frequency" (Interagency Advisory Committee on Water Data, 1982; hereinafter referred to as Bulletin 17B). PeakFQ, a computer program developed by the USGS (Flynn and others, 2006) was used to perform the Bulletin 17B flood-frequency analyses.

The nine index stations used in the RAR to estimate long-term PK1.5, PK2, and PK2.33 satisfied the criteria for selection of long-term index stations specified by Bakke and others (1999). For estimating long-term $T$-year peak flows at the three CMR stations, OLS regression equations relating the PK1.5, PK2, and PK2.33 (dependent variables) to the study period PKM (explanatory variable) were developed. Procedures to determine suitability of the regression to provide acceptable results were identical to those used for estimating monthly and annual streamflow characteristics.

The RAR regression equations (table 5) were determined to provide acceptable results for estimating the PK1.5, PK2, and PK2.33 for the three CMR stations (sites 2, 4, and 14; table 1 and fig. 1). As with the estimates for monthly and annual streamflow characteristics, retransformation bias for the PK1.5, PK2, and PK2.33 was compensated for by multiplying by a nonparametric bias-correction factor (Duan, 1983), which is presented in table 5. The relations used for estimating the PK2 are illustrated in figure 7. Estimates of the PK1.5, PK2, and PK2.33 for the short-term CMR gaging stations are presented in table 6 .

\section{Estimation of Streamflow Characteristics at Ungaged Sites}

Methods for estimating streamflow characteristics at ungaged sites also were needed by the U.S. Fish and Wildlife Service. Regression analyses that relate individual streamflow characteristics to various basin and climatic characteristics for gaging stations were performed to develop regional regression equations to estimate streamflow characteristics at ungaged sites. Of particular interest to the FWS in the process of negotiating water rights is the bankfull discharge, which is an index of streamflow that is considered to be closely related to channel shape, size, and slope (Lawlor, 2004). The PK2 commonly is used to approximate the bankfull discharge (Lawlor, 2004; Wilkerson, 2008). However, various studies have found that the peak-flow recurrence interval associated with the bankfull discharge is variable (Williams, 1978), generally is less than 5 years, and might be more closely approximated by the PK1.5 or the PK2.33 at many stream locations (U.S. Environmental Protection Agency, 2006). Accordingly, separate regression equations for the PK1.5, PK2, and PK2.33 were developed for this study. Determination of the $T$-year peak flow most closely associated with the bankfull discharge for tributaries that cross CMR was beyond the scope of the current (2008) study. However, the bankfull discharge for most streams probably will be within the range of the PK1.5 and PK2.33.

Selected basin and climatic characteristics that were considered as potential explanatory variables in regression analyses for estimating streamflow characteristics at ungaged sites are presented in table 7. All basin characteristics considered were determined by using a geographic information system (GIS) and NHDPlus (Horizon Systems Corporation, 2006), which is an integrated suite of geospatial datasets that determine stream networks, drainage boundaries, selected topographic characteristics, selected climatic characteristics, and selected basin land-cover characteristics. Primary datasets incorporated into NHDPlus include the 1:100,000 scale National Hydrography Dataset (U.S. Geological Survey, 2007), the 30-meter resolution National Elevation Dataset (U.S. Geological Survey, 2006), the 1:24,000 scale Watershed Boundary Dataset (Natural Resources Conservation Service, 2008b), the 30-meter resolution 2006 National Land Cover Dataset (U.S. Environmental Protection Agency, 2007), and the 2-kilometer resolution Parameter-elevation Regressions on Independent Slopes Model (PRISM) for estimating climatic variables using 1971-2000 data (Daly, 1996; Natural Resources Conservation Service, 2008a).

\section{Estimation of Monthly and Annual Streamflow Characteristics at Ungaged Sites}

Thirteen gaging stations (table 1 and fig. 1) were used in developing regression equations for monthly and annual streamflow characteristics. These gaging stations were selected because they generally are close to the study area. The watersheds of the gaging stations located outside of the study area generally are topographically and hydrologically similar to watersheds within the study area. Ten of the 13 stations (sites 8, 15, 20, 21, 23, 25, 30, 32, 38, and 45) had 10 or more years of continuous streamflow records (through water year 2005); monthly and annual streamflow characteristics for these gaging stations were determined from recorded data (Supplement 3 at the back of this report). Three of the 13 gaging stations (sites 2, 4, and 14) were CMR stations with record only during the study period. Estimated monthly 
Table 5. Regression equations for estimating peak-flow characteristics for the short-term gaging stations.

[Equations were developed by using the Regional Adjustment Relationship. Abbreviations: PK1.5, 1.5-year recurrence interval peak flow; PK2, 2-year recurrence interval peak flow; PK2.33, 2.33-year recurrence interval peak flow; PKM, mean peak flow; RBCF, retransformation bias-correction factor; p-value, significance level; $\mathrm{R}^{2}$, coefficient of determination; SEE, average standard error of estimate (in percent)]

\begin{tabular}{lllrrr}
\hline $\begin{array}{c}\text { Long-term } \\
\text { streamflow } \\
\text { characteristic }\end{array}$ & \multicolumn{1}{c}{ Equation } & RBCF & $\mathbf{R}^{2}$ & SEE & p-value \\
\hline PK1.5 & $=2.1$ PKM(study period $)^{0.81}$ & 1.03 & 0.81 & 76.6 & 0.002 \\
PK2 & $=3.8$ PKM(study period $)^{0.80}$ & 1.03 & .80 & 78.5 & .003 \\
PK2.33 & $=5.0$ PKM(study period $)^{0.80}$ & 1.04 & .80 & 79.9 & .003 \\
\hline
\end{tabular}

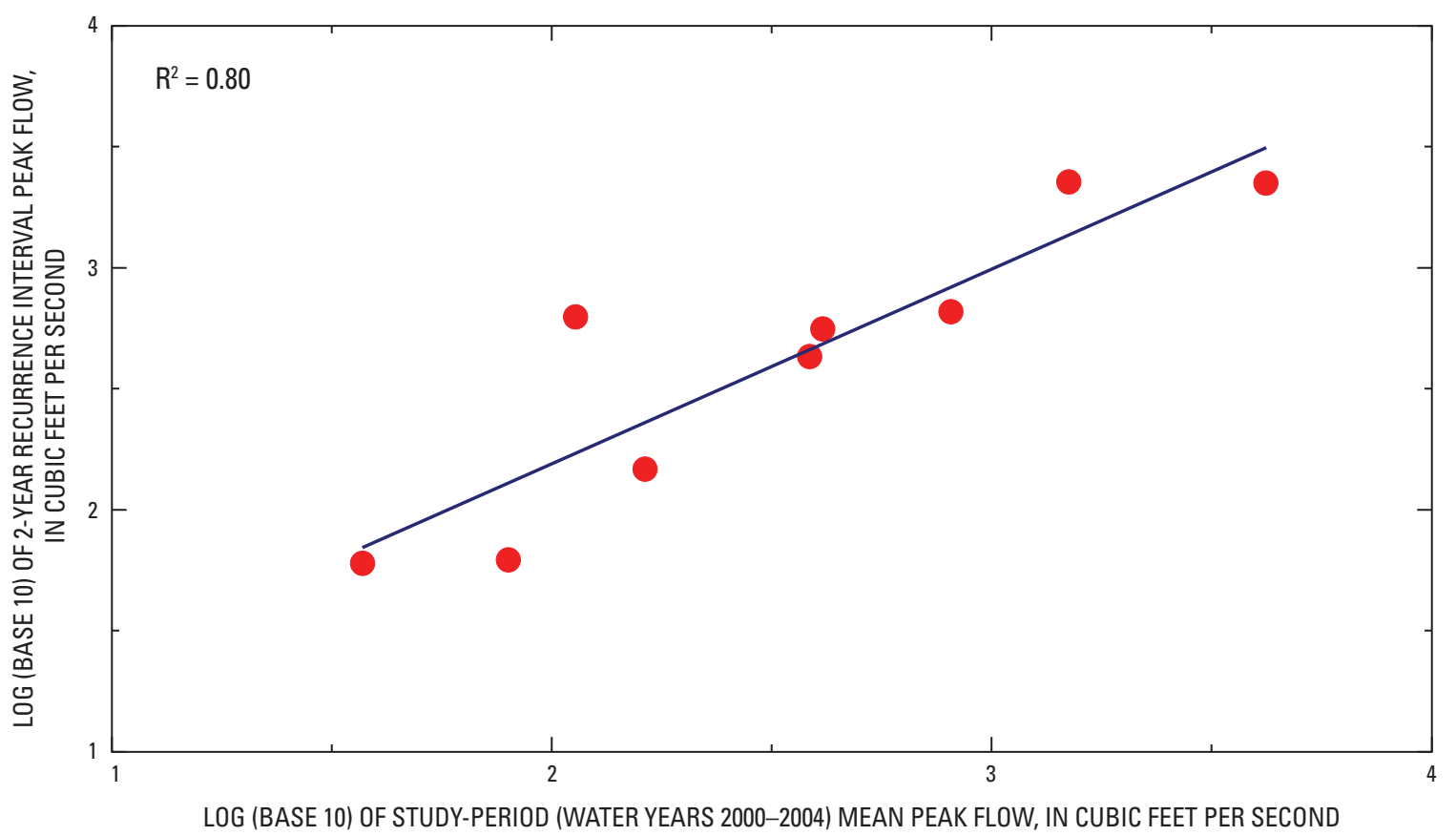

EXPLANATION

2-year recurrence interval peak flow versus study period (water years 2000-2004) mean peak flow for a given long-term index gaging station

Ordinary least-squares regression line for 2-year recurrence interval peak flow

Figure 7. Regional Adjustment Relationship regression relations used to estimate the 2-year recurrence interval peak flow for the short-term gaging stations.

and annual streamflow characteristics (table 4) determined by using the RAR and estimation coefficients were used in the regression analyses for these stations. One of the CMR stations (site 3) had a much smaller drainage area than the other gaging stations and consistently had significantly highleverage and high-influence values (as discussed in Helsel and Hirsch, 2002, p. 245-248) that substantially affected regression results; this gaging station was excluded from the regression analyses for monthly and annual streamflow char- acteristics. All data were transformed to base-10 logarithms prior to analysis. Any streamflow characteristic that was less than $0.01 \mathrm{ft}^{3} / \mathrm{s}$ was assigned a value of $0.01 \mathrm{ft}^{3} / \mathrm{s}$.

For each monthly and annual streamflow characteristic (Q.90, Q.80, Q.50, Q.20, and QM), preliminary OLS regressions were performed to identify the most influential explanatory variables and select a regression model for subsequent weighted least squares (WLS) regression. Regression models were selected on the basis of (1) determining that explanatory 
Table 6. Estimates of peak-flow characteristics for the short-term gaging stations.

[Peak-flow characteristics (in cubic feet per second) estimated by using the Regional Adjustment Relationship. Abbreviations: PK1.5, 1.5-year recurrence interval peak flow; PK2, 2-year recurrence interval peak flow; PK2.33, 2.33-year recurrence interval peak flow; PKM, mean peak flow]

\begin{tabular}{ccccrrr}
\hline $\begin{array}{c}\text { Site number } \\
\text { (fig. 1) }\end{array}$ & $\begin{array}{c}\text { Station } \\
\text { number }\end{array}$ & \multicolumn{1}{c}{ Station name } & $\begin{array}{c}\text { PKM for study period } \\
\text { (water years 2000-2004) }\end{array}$ & PK1.5 & PK2 & PK2.33 \\
\hline 2 & 06115270 & Armells Creek near Landusky & 1,260 & 668 & 1,230 & 1,570 \\
4 & 06115350 & Rock Creek near Landusky & 587 & 362 & 665 & 852 \\
14 & 06130650 & Hell Creek near Jordan & 927 & 523 & 960 & 1,230 \\
\hline
\end{tabular}

Table 7. Selected basin and climatic characteristics considered as potential explanatory variables in regression analyses for estimating streamflow characteristics at ungaged sites.

\begin{tabular}{|c|c|c|}
\hline $\begin{array}{l}\text { Basin or climatic } \\
\text { characteristic }\end{array}$ & Description & References \\
\hline Drainage area & $\begin{array}{l}\text { Area that drains to a stream point, in square miles, deter- } \\
\text { mined from 30-meter resolution National Elevation } \\
\text { Dataset, 1:24,000 scale Watershed Boundary Dataset, } \\
\text { and 1:100,000 scale National Hydrography Dataset }\end{array}$ & $\begin{array}{l}\text { Horizon Systems Corporation (2006), Natural Resources } \\
\text { Conservation Service (2008b), U.S. Geological Survey } \\
\text { (2006). }\end{array}$ \\
\hline Mean elevation & $\begin{array}{l}\text { Basinwide mean elevation, in feet, determined from } \\
\text { 30-meter resolution National Elevation Dataset }\end{array}$ & $\begin{array}{l}\text { Horizon Systems Corporation (2006), U.S. Geological } \\
\text { Survey (2006). }\end{array}$ \\
\hline Maximum elevation & $\begin{array}{l}\text { Maximum elevation of basin, in feet, determined from } \\
\text { 30-meter resolution National Elevation Dataset }\end{array}$ & $\begin{array}{l}\text { Horizon Systems Corporation (2006), U.S. Geological } \\
\text { Survey (2006). }\end{array}$ \\
\hline Minimum elevation & $\begin{array}{l}\text { Minimum elevation of basin, in feet, determined from } \\
\text { 30-meter resolution National Elevation Dataset }\end{array}$ & $\begin{array}{l}\text { Horizon Systems Corporation (2006), U.S. Geological } \\
\text { Survey (2006). }\end{array}$ \\
\hline Relief & $\begin{array}{l}\text { Difference between maximum and minimum elevation } \\
\text { of basin, in feet, determined from 30-meter resolution } \\
\text { National Elevation Dataset }\end{array}$ & $\begin{array}{l}\text { Horizon Systems Corporation (2006), U.S. Geological } \\
\text { Survey (2006). }\end{array}$ \\
\hline $\begin{array}{l}\text { Mean annual } \\
\text { precipitation }\end{array}$ & $\begin{array}{l}\text { Basinwide mean annual precipitation, in inches, deter- } \\
\text { mined from 2-kilometer resolution Parameter-elevation } \\
\text { Regressions on Independent Slopes Model (PRISM) }\end{array}$ & $\begin{array}{l}\text { Daly (1996), Horizon Systems Corporation (2006), } \\
\text { Natural Resources Conservation Service (2008a). }\end{array}$ \\
\hline Percent forest & $\begin{array}{l}\text { Basinwide forest cover, in percent, determined from the } \\
\text { 30-meter resolution National Land Cover Dataset }\end{array}$ & $\begin{array}{l}\text { Horizon Systems Corporation (2006), U.S. Environmen- } \\
\text { tal Protection Agency (2007). }\end{array}$ \\
\hline Percent lakes & $\begin{array}{l}\text { Basinwide lake cover, in percent, determined from the } \\
\text { 1:100,000 scale National Hydrography Dataset }\end{array}$ & $\begin{array}{l}\text { Horizon Systems Corporation (2006), U.S. Geological } \\
\text { Survey (2007). }\end{array}$ \\
\hline Compactness ratio & $\begin{array}{l}\text { A measure of basin shape related to basin perimeter and } \\
\text { drainage area, determined from 30-meter resolution } \\
\text { National Elevation Dataset, 1:24,000 scale Watershed } \\
\text { Boundary Dataset, and 1:100,000 scale National } \\
\text { Hydrography Dataset }\end{array}$ & $\begin{array}{l}\text { Horizon Systems Corporation (2006), Natural Resources } \\
\text { Conservation Service (2008b), U.S. Geological Survey } \\
\text { (2006). }\end{array}$ \\
\hline
\end{tabular}


variables were statistically significant ( $\mathrm{p}$-value less than 0.05 ); (2) minimizing Mallow's Cp and the Press statistic (Helsel and Hirsch, 2002, p. 313) among different candidate models; (3) reviewing regression diagnostics to ensure that final regression models were not substantially affected by outliers, high-leverage values, high-influence values, or non-normally distributed residuals (by using methods described by Helsel and Hirsch, 2002, p. 228-251); (4) determining that the overall statistical significance exceeded 95 percent (p-value was less than 0.05); and (5) determining that the SEE was less than about 100 percent. As a result of the preliminary OLS regression analyses, the explanatory variables used in the final WLS regression models for any of the monthly and annual streamflow characteristics were drainage area $(A)$ and relief $(R E L)$. Data for these variables for all gaging stations are presented in Supplement 4 (at the back of this report). Supplement 4 also includes data for other basin and climatic characteristics (that were not used in final regression models), as well as manually determined basin and climatic characteristics for informational purposes.

Final regressions were performed by using WLS regression. Because individual gaging stations have varying periods of record that might be associated with climatically different conditions, the reliability of calculations of streamflow characteristics determined by using recorded data might vary among gaging stations. Generally, calculations of streamflow characteristics for gaging stations with shorter periods of record are expected to be less reliable than calculations for gaging stations with longer periods of record. Weighting the streamflow characteristics for a gaging station proportionally to record length of the station helps to compensate for differences in the reliability of the characteristics. However, appropriate weighting factors also incorporate information on the variance of the streamflow records for a given gaging station, which helps to reduce effects of nonconstant variance on regression results. For this study, a weighting factor developed by Ries and Friesz (2000) that considers both record length and variance of the streamflow characteristic was used. The weighting factor for each gaging station was calculated by using the following equation:

$$
W T_{\mathrm{i}}=\left(Y_{\mathrm{i}} / \bar{Y}_{1, \mathrm{~N}}\right) /\left(V_{\mathrm{i}} / \bar{V}_{1, \mathrm{~N}}\right)
$$

where

$$
\begin{gathered}
W T_{\mathrm{i}} \quad \begin{array}{c}
\text { is the weighting factor for gaging station } i, \\
\text { dimensionless; }
\end{array} \\
Y_{\mathrm{i}} \quad \begin{array}{c}
\text { is the number of years of record for gaging } \\
\text { station } i \text {; }
\end{array} \\
\bar{Y}_{1, \mathrm{~N}} \quad \begin{array}{c}
\text { is the mean number of years of record for all } \\
\text { gaging stations; }
\end{array} \\
N \quad \begin{array}{c}
\text { is the number of gaging stations used in the } \\
\text { regression analysis; }
\end{array} \\
V_{\mathrm{i}} \quad \begin{array}{l}
\text { is the variance of the streamflow characteristic } \\
\text { for gaging station } i \text {; and }
\end{array} \\
\bar{V}_{1, \mathrm{~N}} \quad \begin{array}{l}
\text { is the mean variance of the streamflow } \\
\text { characteristic for all gaging stations. }
\end{array}
\end{gathered}
$$

Regression equations for the annual Q.50, Q.20, and QM and retransformation bias-correction factors (Duan, 1983) are presented in table 8 . Individual regression analyses were performed to investigate if acceptable equations for estimating Q.90, Q.80, Q.50, Q.20, and QM on a monthly basis and also on an annual basis could be developed. Acceptable equations were developed for estimating QM for the months of February, March, April, June, and July, and Q.50, Q.20, and QM on an annual basis. However, equations for QM for the months of February, March, April, June, and July were determined to be less consistent and reliable than the use of estimation coefficients (table 3) applied to the regression equation results for the annual QM (table 8). Thus, the regression equations for the long-term mean streamflows for the months of February, March, April, June, and July are not reported. The monthly and annual streamflow characteristics for which acceptable regression equations were not developed or reported can be estimated by using the estimation coefficients (table 3 ).

\section{Estimation of Peak-Flow Characteristics at Ungaged Sites}

Forty-two gaging stations (indicated in table 1) were used in developing regression equations for peak-flow characteristics. These gaging stations were selected because they are in or generally close to the study area. The watersheds of the gaging stations located outside of the study area generally are topographically and hydrologically similar to watersheds within the study area. Thirty-nine of the gaging stations had 10 or more years of annual peak-flow records (on the basis of data through water year 2005). The PK1.5, PK2, and PK2.33 for these 39 gaging stations (Supplement 5 at the back of this report) were determined from recorded data by using procedures described in Bulletin 17B (Interagency Advisory Committee on Water Data, 1982) and incorporated in the PEAKFQ computer program (Flynn and others, 2006). Three of the 42 gaging stations were CMR stations (sites 2, 4, and 14) with annual peak-flow records only during the study period. Estimated PK1.5, PK2, and PK2.33 for these three gaging stations (table 6) were determined by using the RAR.

In developing regression equations for peak-flow characteristics, the study area was divided into two regions: (1) the North Region, which includes that part of the study area north of the Missouri River, and (2) the South Region, which includes that part of the study area south of the Missouri River (fig. 1). Eleven gaging stations north of the Missouri River (table 1 and fig. 1) were used to develop regression equations for the North Region. Thirty-one gaging stations south of the Missouri River (table 1 and fig. 1) were used to develop regression equations for the South Region.

For each region and each peak-flow characteristic, preliminary OLS regressions were performed to identify the most influential explanatory variables and select a regression model for subsequent GLS regression (Tasker and Stedinger, 1989). Regression models were selected on the 
Table 8. Regression equations for estimating annual streamflow characteristics at ungaged sites.

\begin{tabular}{|c|c|c|c|c|}
\hline $\begin{array}{c}\text { Long-term } \\
\text { streamflow } \\
\text { characteristic }\end{array}$ & Equation & RBCF & SEE & p-value \\
\hline Annual Q.50 & $=0.30 A^{0.49}(R E L / 1,000)^{0.55}$ & 1.05 & 49.0 & $<0.001$ \\
\hline Annual Q.20 & $=0.69 A^{0.52}(R E L / 1,000)^{0.70}$ & 1.03 & 65.1 & .001 \\
\hline Annual QM & $=0.56 A^{0.48}(R E L / 1,000)^{0.59}$ & 1.04 & 52.0 & $<.001$ \\
\hline
\end{tabular}

basis of (1) determination of significant (p-value less than 0.05 ) explanatory variables; (2) minimizing Mallow's $\mathrm{Cp}$ and the Press statistic (Helsel and Hirsch, 2002, p. 313) among different candidate models; (3) reviewing regression diagnostics to ensure the final regression models were not substantially affected by outliers, high-leverage values, high-influence, values or non-normally distributed residuals (by using methods described by Helsel and Hirsch, 2002, p. 228-251); (4) determining that the overall statistical significance exceeded 95 percent (that is, the p-value was less than 0.05); and (5) determining that the SEP was less than about 100 percent. Explanatory variables used in final regression models for any of the peak-flow characteristics were area $(A)$ and basinwide mean elevation $(E)$. Data for these variables for all gaging stations are presented in Supplement 4. Supplement 4 also includes data for other basin and climatic characteristics (that were not used in final regression models), as well as manually determined basin and climatic characteristics for informational purposes.

For each region, final regressions were performed by using GLS regression (Tasker and Stedinger, 1989). GLS regression accounts for time-sampling error that is inherent when individual gaging stations have been operated for different lengths of time and under different climatic conditions. GLS regression also accounts for cross correlation of annual peak flows among different gaging stations. For this study, GLS regression was applied by using a program based on methods described by Stedinger and Tasker (1985) and Tasker and Stedinger (1989) and discussed in Kenney and others (2007). Numerical methods used in the program to estimate time-sampling error are based on statistics for the log-Pearson Type III probability distribution, which routinely is used for determining peak-flow magnitude and frequency relations (Interagency Advisory Committee on Water Data, 1982). Thus, GLS regression is appropriate for developing regression equations for peak-flow characteristics but was not used for developing regression equations for monthly and annual streamflow characteristics, which are not necessarily well represented by the log-Pearson Type III probability distribution. Acceptable equations were developed for the PK1.5, PK2, and PK2.33. Regression equations for estimating peak-flow characteristics and retransformation bias-correction factors (Duan, 1983) are presented in table 9. SEPs for regression equations for the PK1.5, PK2, and PK2.33 for the North Region were 56.6, 62.1, and 63.8 percent, respectively. SEPs for regression equations for the PK1.5, PK2, and PK2.33 for the South Region were 62.1, 57.3, and 55.6 percent, respectively.

\section{Limitations on Use of the Regression Equations}

The following limitations need to be considered when using the regression equations presented in this report to estimate monthly and annual streamflow characteristics and peak-flow characteristics for ungaged sites in the study area: (1) the regression equations should not be used for sites near dams, flood-detention structures, and other manmade structures that might substantially affect the specific streamflow characteristics being estimated; (2) the regression equations generally should be used only for sites within the study area; (3) basin characteristics used in the regression equations should be determined by using methods identical to those used in this study; and (4) the regression equations generally should be used only for sites that have basin characteristics that are within the range of characteristics used to develop the regression equations (table 10).

\section{Estimated Streamflow Characteristics for Selected Ungaged Sites in Charles M. Russell National Wildlife Refuge}

Of particular interest to the FWS are estimates of monthly and annual streamflow characteristics and peak-flow characteristics at ungaged sites (fig. 8) on tributary streams where they enter CMR, and also where they enter Fort Peck Reservoir. Basin characteristics for these ungaged sites are presented in Supplement 6 (at the back of this report). Esti- 
Table 9. Regression equations for estimating peak-flow characteristics at ungaged sites.

[Abbreviations: A, drainage area (in square miles); E, basinwide mean elevation (in feet above North American Vertical Datum of 1988); EYR, equivalent years of record; ME, average model error (in percent); PK1.5, 1.5-year recurrence interval peak flow; PK2, 2-year recurrence interval peak flow; PK2.33, 2.33-year recurrence interval peak flow; RBCF, retransformation bias-correction factor; SEP, average standard error of prediction (in percent); TE, time-sampling error (in percent)]

\begin{tabular}{|c|c|c|c|c|c|c|}
\hline Peak-flow characteristic & Equation & RBCF & SEP & TE & ME & EYR \\
\hline \multicolumn{7}{|c|}{ North Region } \\
\hline PK1.5 & $=16 A^{0.39}$ & 1.08 & 56.6 & 8.5 & 48.1 & 8.8 \\
\hline PK2 & $=28 A^{0.42}$ & 1.06 & 62.1 & 8.8 & 53.3 & 7.1 \\
\hline PK2.33 & $=35 A^{0.43}$ & 1.05 & 63.8 & 8.9 & 54.9 & 6.9 \\
\hline \multicolumn{7}{|c|}{ South Region } \\
\hline PK1.5 & $=71 A^{0.62}(E / 1,000)^{-1.80}$ & 1.06 & 62.1 & 5.1 & 57.0 & 7.0 \\
\hline PK2 & $=155 A^{0.60}(E / 1,000)^{-1.92}$ & 1.05 & 57.3 & 4.3 & 53.0 & 5.6 \\
\hline PK2.33 & $=214 A^{0.59}(E / 1,000)^{-1.97}$ & 1.04 & 55.6 & 4.1 & 51.5 & 5.3 \\
\hline
\end{tabular}

Table 10. Ranges for basin characteristics used to develop regression equations for estimating streamflow characteristics at ungaged sites.

[Elevation information is referenced to the North American Vertical Datum of 1988. Symbol: --, not applicable]

\begin{tabular}{lccc}
\hline \multicolumn{1}{c}{ Type of regression equation } & $\begin{array}{c}\text { Drainage area }(\boldsymbol{A}), \\
\text { in square miles }\end{array}$ & $\begin{array}{c}\text { Relief }(\boldsymbol{R E L}), \\
\text { in feet }\end{array}$ & $\begin{array}{c}\text { Basinwide mean elevation }(\boldsymbol{E}), \\
\text { in feet }\end{array}$ \\
\hline Annual streamflow characteristics (table 8) & $70-2,551$ & $606-4,149$ & -- \\
Peak-flow characteristics (table 9) for North Region & $0.9-920$ & -- & -- \\
Peak-flow characteristics (table 9) for South Region & $1.1-2,551$ & -- & $2,398-4,003$ \\
\hline
\end{tabular}

mated monthly and annual streamflow characteristics for these ungaged sites (derived by using regression equations, table 8, and estimation coefficients, table 3) are presented in Supplement 7 (at the back of this report) and example plots of monthly streamflow characteristics for selected ungaged sites are shown in figure 9. Example plots of selected annual streamflow characteristics for various exceedance probabilities for the selected ungaged sites are shown in figure 10 .

The estimated mean and median monthly streamflows for the selected ungaged sites (fig. 9) are similar to those of longterm gaging stations close to the study area (fig. 6). Streams in the northeastern plains of Montana generally are characterized by higher streamflows during February through August and lower streamflows during September through January. For most streams, March and April, when most snowmelt runoff typically occurs in northeastern Montana, have the highest mean monthly streamflow. Spring rainstorms also contribute to higher streamflows in March and April. Mean monthly streamflow for February typically is larger than late fall and early winter streamflows, indicating that during some years snowmelt begins in February. Some streams show a midspring (about April or May) decrease in streamflow following completion of snowmelt at lower elevations. Late spring and summer rainstorms can increase streamflow during the months of June and July. Streamflows then generally decrease from August through the fall.

The estimated median monthly and annual streamflows generally are substantially less than the estimated mean monthly and annual streamflows for the ungaged sites. This pattern also was noted by Parrett (2006) for several tributaries to the Milk River that are near the study area. Large differences between median and mean monthly and annual streamflows are typical of streams with highly variable streamflow from year to year. Differences between median and mean monthly streamflows are especially large for some months (including January, February, August, September, and October) when streamflows typically transition between baseflow and runoff dominance.

The estimated long-term streamflow characteristics for the selected ungaged sites generally indicate similar annual streamflow patterns to those of the long-term gaging stations. However, the methods used to estimate the monthly and annual streamflow characteristics (that is, the regression equations, table 8 , and estimation coefficients, table 3 ) for 


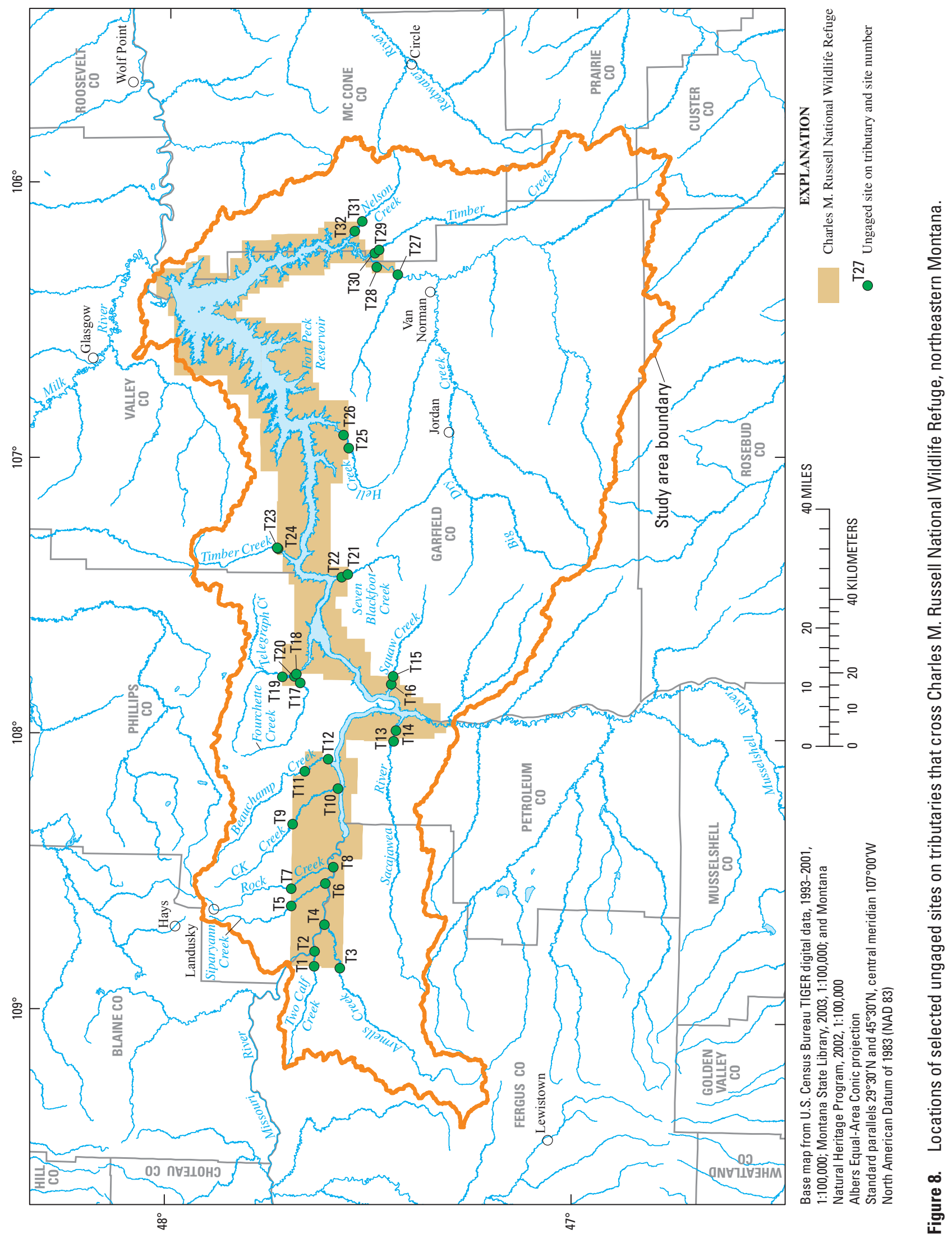




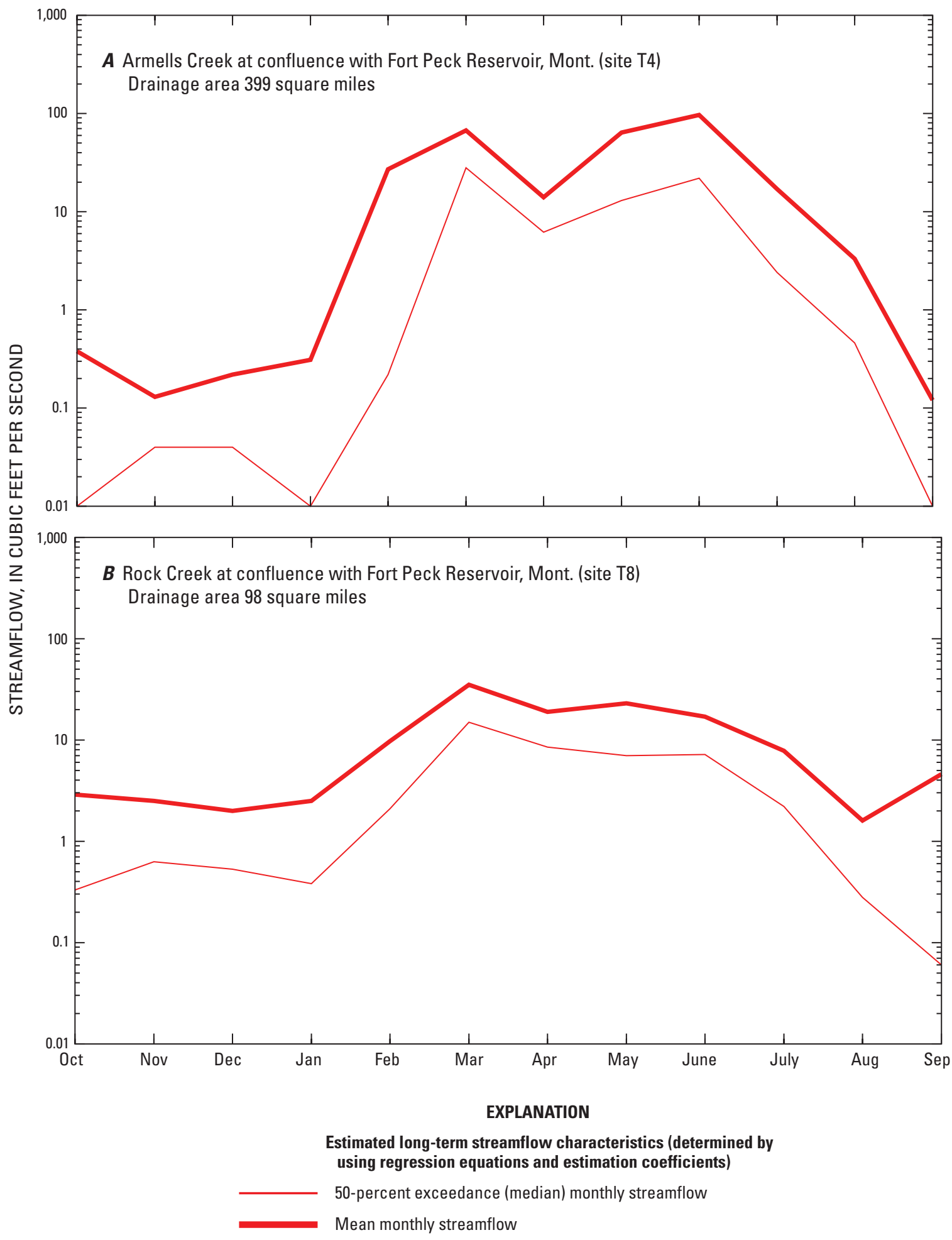

Figure 9. Estimated long-term monthly streamflow characteristics (derived by using regression equations, table 8, and estimation coefficients, table 3) for selected ungaged sites. $A$, Armells Creek at confluence with Fort Peck Reservoir, Mont.; $B$, Rock Creek at confluence with Fort Peck Reservoir, Mont.; $C$, Big Dry Creek at confluence with Fort Peck Reservoir, Mont.; $D$, Nelson Creek at confluence with Fort Peck Reservoir, Mont. 


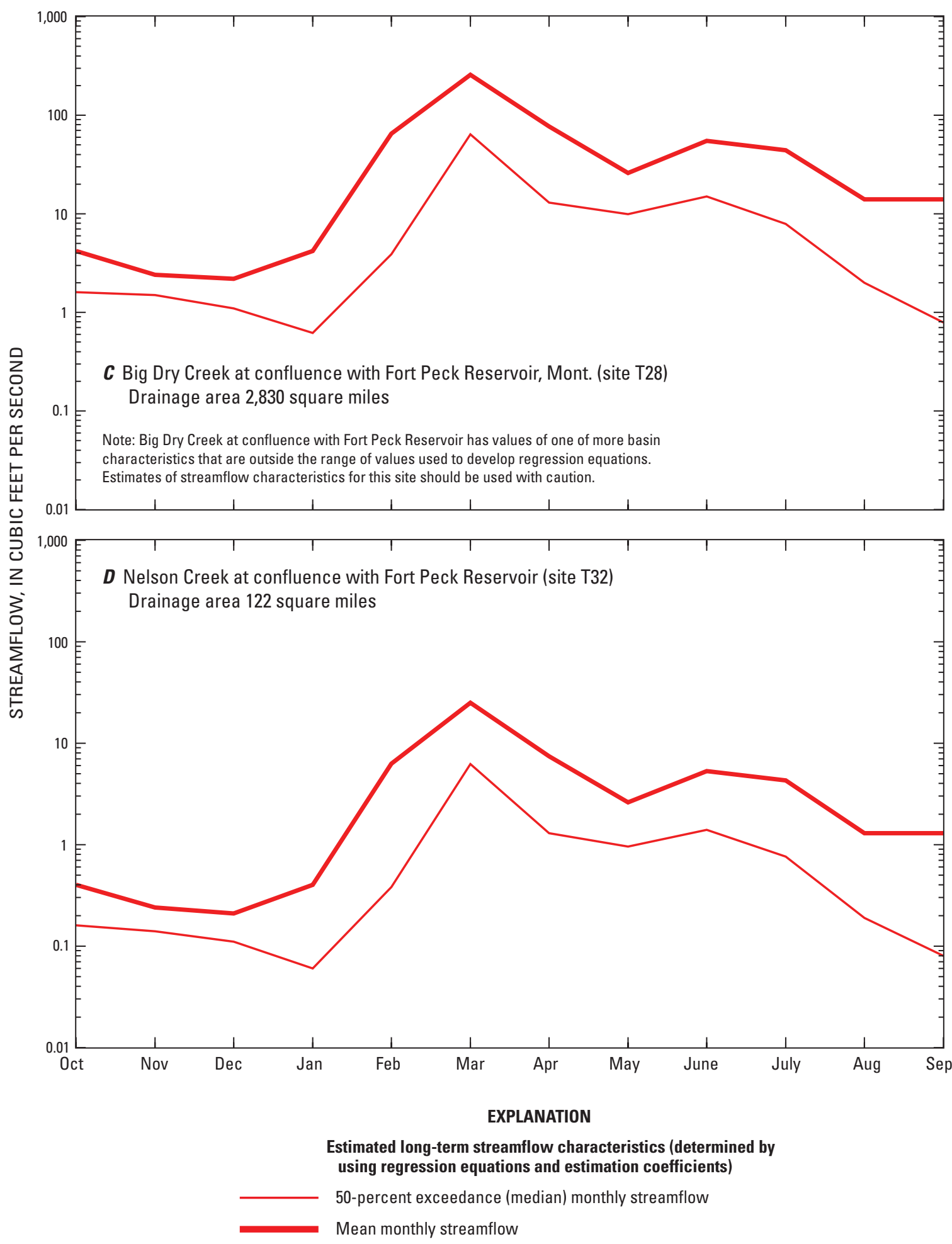

Figure 9. Estimated long-term monthly streamflow characteristics (derived by using regression equations, table 8, and estimation coefficients, table 3 ) for selected ungaged sites. $A$, Armells Creek at confluence with Fort Peck Reservoir, Mont.; $B$, Rock Creek at confluence with Fort Peck Reservoir, Mont.; $C$, Big Dry Creek at confluence with Fort Peck Reservoir, Mont.; $D$, Nelson Creek at confluence with Fort Peck Reservoir, Mont.-Continued 


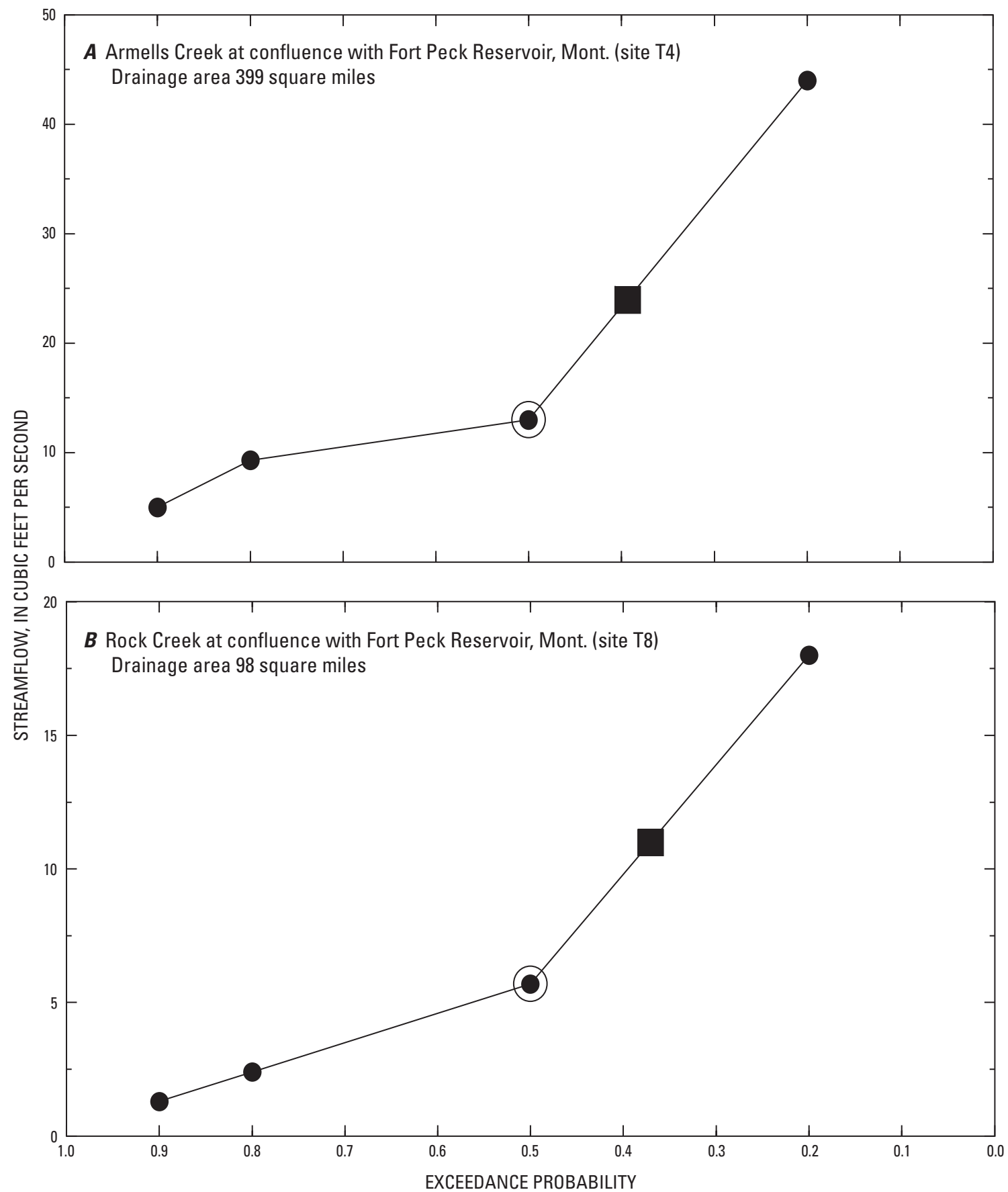

EXPLANATION

Estimated annual streamflow for indicated exceedance probability

Estimated median annual streamflow

Estimated mean annual streamflow

Line connecting exceedance probabilities is presented to show general patterns; variability between indicated exceedance probabilities might not be linear

Figure 10. Estimated annual streamflow (derived by using regression equations, table 8, and estimation coefficients, table 3) for various exceedance probabilities for selected ungaged sites. $A$, Armells Creek at confluence with Fort Peck Reservoir, Mont.; $B$, Rock Creek at confluence with Fort Peck Reservoir, Mont.; $C$, Big Dry Creek at confluence with Fort Peck Reservoir, Mont.; $D$, Nelson Creek at confluence with Fort Peck Reservoir, Mont. 


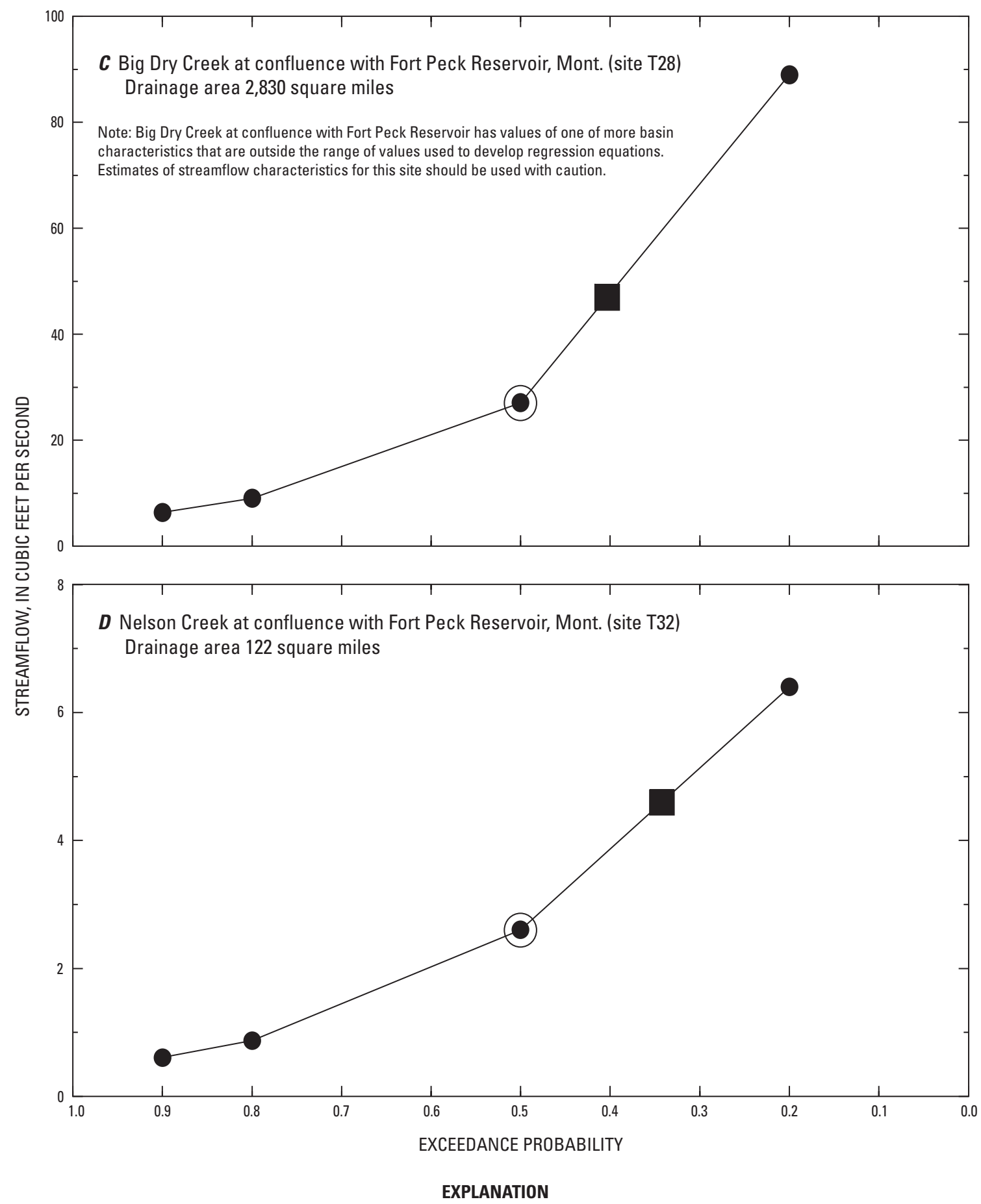

- Estimated annual streamflow for indicated exceedance probability

Estimated median annual streamflow

Estimated mean annual streamflow

Line connecting exceedance probabilities is presented to show general patterns; variability between indicated exceedance probabilities might not be linear

Figure 10. Estimated annual streamflow (derived by using regression equations, table 8, and estimation coefficients, table 3 ) for various exceedance probabilities for selected ungaged sites. $A$, Armells Creek at confluence with Fort Peck Reservoir, Mont.; B, Rock Creek at confluence with Fort Peck Reservoir, Mont.; $C$, Big Dry Creek at confluence with Fort Peck Reservoir, Mont.; $D$, Nelson Creek at confluence with Fort Peck Reservoir, Mont.-Continued 
the ungaged sites homogenize general regional streamflow patterns. Thus, actual site-to-site variability is very likely to be larger than that indicated by the estimates presented in Supplement 7 and figure 9.

Estimated peak-flow characteristics for the selected ungaged sites (estimated by using regression equations, table 9) are presented in Supplement 8 (at the back of this report), and example plots of peak-flow characteristics for ungaged sites are shown in figure 11. Parrett and Johnson (2003) noted that peak-flow characteristics for streams in eastern Montana tend to be more variable, both spatially and temporally, than those for streams in other parts of Montana and that most annual peak flows in the study area occur during the months of March through July.

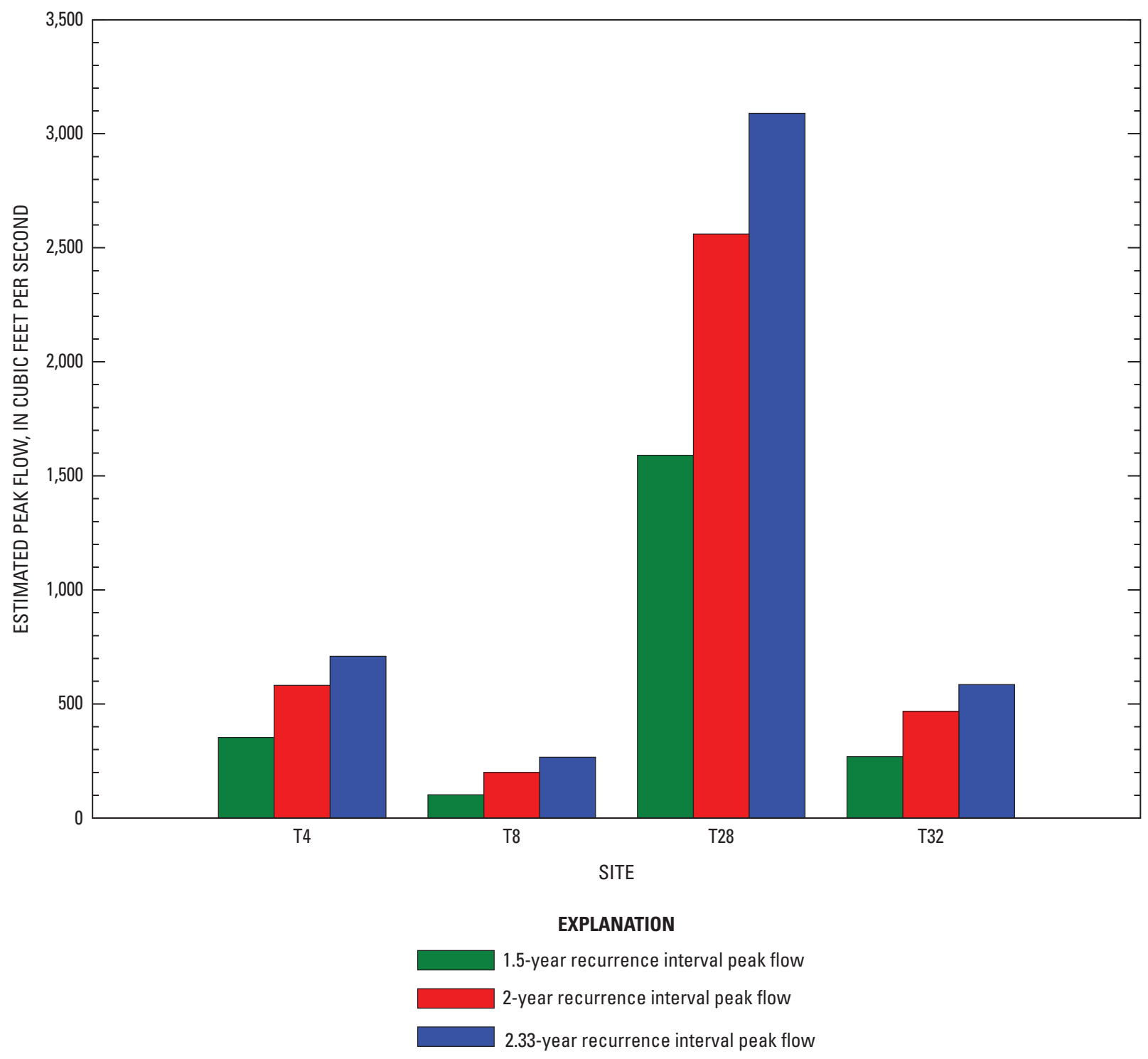

Figure 11. Estimated 1.5-, 2-, and 2.33-year recurrence interval peak flows (determined by using regression equations, table 9) for selected ungaged sites: T4 (Armells Creek at confluence with Fort Peck Reservoir, Mont.), T8 (Rock Creek at confluence with Fort Peck Reservoir, Mont.), T28 (Big Dry Creek at confluence with Fort Peck Reservoir, Mont.), and T32 (Nelson Creek at confluence with Fort Peck Reservoir, Mont.). 


\section{Summary}

Charles M. Russell National Wildlife Refuge (CMR) encompasses about 1.1 million acres (including Fort Peck Reservoir on the Missouri River) in northeastern Montana. To ensure that sufficient streamflow remains in the tributary streams to maintain the riparian corridors, the U.S. Fish and Wildlife Service (FWS) is negotiating water-rights issues with the Reserved Water Rights Compact Commission of Montana. These negotiations require accurate information about current and long-term streamflow characteristics for Missouri River tributary streams that cross CMR. However, there are very few long-term streamflow data for these streams. Thus, the U.S. Geological Survey (USGS), in cooperation with the FWS, conducted a study to gage, for a short period, selected streams that cross CMR, and analyze data to estimate long-term streamflow characteristics for CMR.

To address the need for streamflow information in CMR, a three-phased approach was used that involved (1) collecting continuous records of daily mean streamflow for a 5-year period (water years 2000-2004, hereinafter referred to as the study period) for five streams that cross CMR, (2) estimating long-term streamflow characteristics for the five gaging stations by using relations between study-period streamflow characteristics and long-term streamflow characteristics for nearby long-term gaging stations to adjust recorded studyperiod streamflow characteristics, and (3) developing regional regression equations to relate streamflow characteristics to basin characteristics. The long-term streamflow characteristics of primary interest include the monthly and annual 90-, 80-, 50-, and 20-percent exceedance streamflows and mean streamflows (Q.90, Q.80, Q.50, Q.20, and QM, respectively), and the 1.5-, 2-, and 2.33-year peak flows (PK1.5, PK2, and PK2.33, respectively).

The Regional Adjustment Relationship (RAR) was investigated for estimating the monthly and annual Q.90, Q.80, Q.50, Q.20, and QM, and the PK1.5, PK2, and PK2.33 for the short-term CMR gaging stations (hereinafter referred to as CMR stations). The conceptual basis of the RAR is that at any given stream site the correlation between a streamflow characteristic for a short period of record and long-term streamflow characteristics is consistent over a somewhat broad and climatically homogeneous region.

For the CMR stations, the RAR regression equations were determined to provide acceptable results for estimating the long-term Q.90, Q.80, Q.50, Q.20, and QM on a monthly basis for the months of March through June, and also on an annual basis. For the months of September through January, the RAR regression equations did not provide acceptable results for any long-term streamflow characteristic. For the month of February, the RAR regression equations provided acceptable results for the long-term Q.50 and QM but poor results for the long-term Q.90, Q.80, and Q.20. For the months of July and August, the RAR provided acceptable results for the long-term Q.50, Q.20, and QM but poor results for the long-term Q.90 and Q.80.

Estimation coefficients were developed for estimating the long-term streamflow characteristics for which the RAR did not provide acceptable results. These coefficients were developed by using continuous streamflow records from streams in the study area or in nearby watersheds that generally are hydrologically similar to the streams that cross CMR. The estimation coefficients were determined by calculating the ratio of a given streamflow characteristic to the mean annual streamflow. Estimation coefficients were developed for three types of watersheds: (1) watersheds with maximum elevations less than about 5,000 ft (above NAVD 88), (2) watersheds on the south side of the Missouri River with maximum elevations greater than about 5,000 ft, and (3) watersheds on the north side of the Missouri River with maximum elevations greater than about $5,000 \mathrm{ft}$. Estimation coefficients for each watershed type and each streamflow characteristic were calculated by determining the weighted average (weighting based on number of years of record) of the ratios of all the selected gaging stations for a given watershed type.

The RAR also was investigated for estimating the longterm PK1.5, PK2, and PK2.33 for three of the CMR stations. The RAR regression equations were determined to provide acceptable results for estimating PK1.5, PK2, and PK2.33 for the three CMR stations.

Methods for estimating streamflow characteristics at ungaged sites also were needed by the FWS. Regression analyses that relate individual streamflow characteristics to various basin and climatic characteristics for gaging stations were performed to develop regression equations to estimate streamflow characteristics at ungaged sites. Selected basin and climatic characteristics that were considered as potential explanatory variables in regression analyses were determined by using a geographic information system.

Individual regression analyses were performed to determine if acceptable equations for estimating Q.90, Q.80, Q.50, Q.20, and QM on a monthly basis and an annual basis could be developed. Final equations for the annual Q.50, Q.20, and QM were developed by using weighted least squares regression. Acceptable equations also were developed for estimating QM for the months of February, March, April, June, and July, and Q.50, Q.20, and QM on an annual basis. However, equations for QM for the months of February, March, April, June, and July were determined to be less consistent and reliable than the use of estimation coefficients applied to the regression equation results for the annual QM. The monthly and annual streamflow characteristics for which acceptable regression equations were not developed or reported can be estimated by using the estimation coefficients.

Individual regression analyses also were performed to investigate if acceptable equations for the PK1.5, PK2, and PK2.33 could be developed. Final equations were developed using generalized least squares regression. In developing regression equations for peak-flow characteristics, the study area was divided into two regions: (1) the North Region, which 
includes that part of the study area north of the Missouri River, and (2) the South Region, which includes that part of the study area south of the Missouri River. Acceptable regression equations were developed for the PK1.5, PK2, and PK2.33.

\section{References Cited}

Alley, W.M., and Burns, A.W., 1983, Mixed station extension of monthly streamflow records: Journal of Hydraulic Engineering, American Society of Civil Engineers, v. 109, no. 10 , p. 1,272-1,284.

Bakke, P.D., Thomas, Robert, and Parrett, Charles, 1999, Estimation of long-term discharge characteristics by regional adjustment: Journal of the American Water Resources Association, v. 35, p. 911-921.

Cooper S.V., and Jean, C., 2001, Wildfire succession in plant communities natural to the Alkali Creek vicinity, Charles M. Russell National Wildlife Refuge, Montana: Technical Report of the Montana Natural Heritage Program, Helena, Montana, $32 \mathrm{p}$.

Daly, Christopher, 1996, Overview of the PRISM model, accessed December 30, 2008, at http://www.prism.oregonstate.edu/docs/overview.html

Duan, Naihua, 1983, A nonparametric retransformation method: Journal of the American Statistical Association, v. 78 , no. 383 , p. 2,353-2,363.

Flynn, K.M., Kirby, W.H., and Hummel, P.R., 2006, User's manual for program PeakFQ, annual flood frequency analysis using Bulletin 17B guidelines: U.S. Geological Survey Techniques and Methods, book 4, chapter B4, 42 p. Available online at http://pubs.usgs.gov/tm/2006/tm4b4/\#title

Frahme, C.W., 1979, Mineral resources of the Charles M. Russell Wildlife Refuge, Fergus, Garfield, McCone, Petroleum, Phillips, and Valley Counties, Montana-Chapter B, Geology and evaluation of the mineral resources of the Charles M. Russell Wildlife Refuge: U.S. Geological Survey OpenFile Report 79-1204, p. 5-42.

Helsel, D.R., and Hirsch, R.M., 2002, Statistical methods in water resources: U.S. Geological Survey Techniques of Water-Resources Investigations, book 4, chap. A3, 524 p. Available online at http://water.usgs.gov/pubs/twri/twri4a3/.

Horizon Systems Corporation, 2006, National Hydrography Dataset Plus, accessed April 14, 2008, at http://www. horizon-systems.com/nhdplus/.
Interagency Advisory Committee on Water Data, 1982, Guidelines for determining flood flow frequency-Bulletin 17B of the Hydrology Subcommittee: U.S. Geological Survey, Office of Water Data Coordination, 183 p., accessed June 5, 2008, at http://water.usgs.gov/osw/bulletin17b/bulletin_17B. html

Jensen, F.S., and Varnes, H.D., 1964, Geology of the Fort Peck area, Garfield, McCone, and Valley Counties, Montana: U.S. Geological Survey Professional Paper 414-F, 48 p.

Kenney, T.A., Wilkowske, C.D., and Wright, S.J., 2007, Methods for estimating magnitude and frequency of peak flows for natural streams in Utah: U.S. Geological Survey Scientific Investigations Report 2007-5158, 28 p.

Koch, R.W., and Smillie, G.M., 1986, Bias in hydrologic prediction using log-transformed regression models: Water Resources Bulletin, v. 22, p. 717-723.

Lawlor, S.M., 2004, Determination of channel morphology characteristics, bankfull discharge, and various design-peak discharges in western Montana: U.S. Geological Survey Scientific Investigations Report 2004-5263, 19 p.

Natural Resources Conservation Service, 2008a, PRISM, accessed April 14, 2008, http://www.wcc.nrcs.usda.gov/ climate/prism.html

Natural Resources Conservation Service, 2008b, Watershed Boundary Dataset (WBD), accessed April 14, 2008, at http://www.ncgc.nrcs.usda.gov/products/datasets/ watershed/.

Omang, R.J., and Parrett, Charles, 1984, A method for estimating mean annual runoff of ungaged streams based on basin characteristics in central and eastern Montana: U.S. Geological Survey Water-Resources Investigations Report 84-4143, 15 p.

Parrett, Charles, 2006, Synthesis of monthly and annual streamflow records (water years 1950-2003) for Big Sandy, Clear, Peoples, and Beaver Creeks in the Milk River basin, Montana: U.S. Geological Survey Scientific Investigations Report 2005-5216, 23 p. Available online only at http:// pubs.usgs.gov/sir/2005/5216/.

Parrett, Charles, and Johnson, D.R., 2003, Methods for estimating flood frequency in Montana based on data through water year 1998: U.S. Geological Survey Water-Resources Investigations Report 03-4308, 101 p.

Parrett, Charles, Johnson, D.R., and Hull, J.A., 1989, Estimates of monthly streamflow characteristics at selected sites in the upper Missouri River basin, base period water years 1937-86: U.S. Geological Survey Water-Resources Investigations Report 89-4082, 103 p. 
Rantz, S.E. and others, 1982, Measurement and computation of streamflow: U.S. Geological Survey Water-Supply Paper $2175,631 \mathrm{p}$.

Ries, K.G., and Friesz, P.J., 2000, Methods for estimating lowflow statistics for Massachusetts streams: U.S. Geological Survey Water-Resources Investigations Report 00-4135, $81 \mathrm{p}$.

Stedinger, J.R., and Tasker, G.D., 1985, Regional hydrologic analysis I-Ordinary, weighted, and generalized leastsquares compared: American Geophysical Union, Water Resources Research, v. 21, no. 9, p. 1,421-1,432.

Tasker, G.D., and Stedinger, J.R., 1989, An operational GLS model for hydrologic regression: Journal of Hydrology, v. 111, p. $361-375$.

U.S. Environmental Protection Agency, 2006, Watershed Assessment of River Stability \& Sediment Supply (WARSSS), Hydrologic Processes-Bankfull Discharge, accessed June 7, 2008, at http://www.epa.gov/warsss/sedsource/ bankfull.htm

U.S. Environmental Protection Agency, 2007, National Land Cover Data (NLCD 2006), accessed April 14, 2008, at http://www.epa.gov/mrlc/nlcd-2006.html
U.S. Fish and Wildlife Service, 2006, Charles M. Russell National Wildlife Refuge, Lewistown, Montana, accessed May 23, 2006, at http://cmr.fws.gov/Annual\%20 Narratives/2002\%20Annual\%20Narrative/Introduction.htm

U.S. Geological Survey, 2006, National Elevation Dataset, accessed April 14, 2008, at http://ned.usgs.gov/.

U.S. Geological Survey, 2007, National Hydrography Dataset, accessed April 14, 2008, at http://nhd.usgs.gov/.

Western Regional Climate Center, 2006, Montana climate summaries, Jordan, Montana, accessed June 13, 2006, at http://www.wrcc.dri.edu/cgi-bin/cliMAIN.pl?mtjord

Wilkerson, G.V., 2008, Improved bankfull discharge prediction using 2-year recurrence-period discharge: Journal of the American Water Resources Association, v. 44, p. 243-258.

Williams, G.P., 1978, Bankfull discharges of rivers: Water Resources Research, v. 14, no. 6, p. 1,141-1,154.

Woods, A.J., Omernik, J.M., Nesser, J.A., Shelden, J., Comstock, J.A., Azevedo, S.H., 2002, Ecoregions of Montana, (2d ed.): U.S. Environmental Protection Agency, Western Ecology Division, accessed October 8, 2008 at http://www. epa.gov/naaujydh/pages/ecoregions/mt_eco.htm 
Supplemental Data 


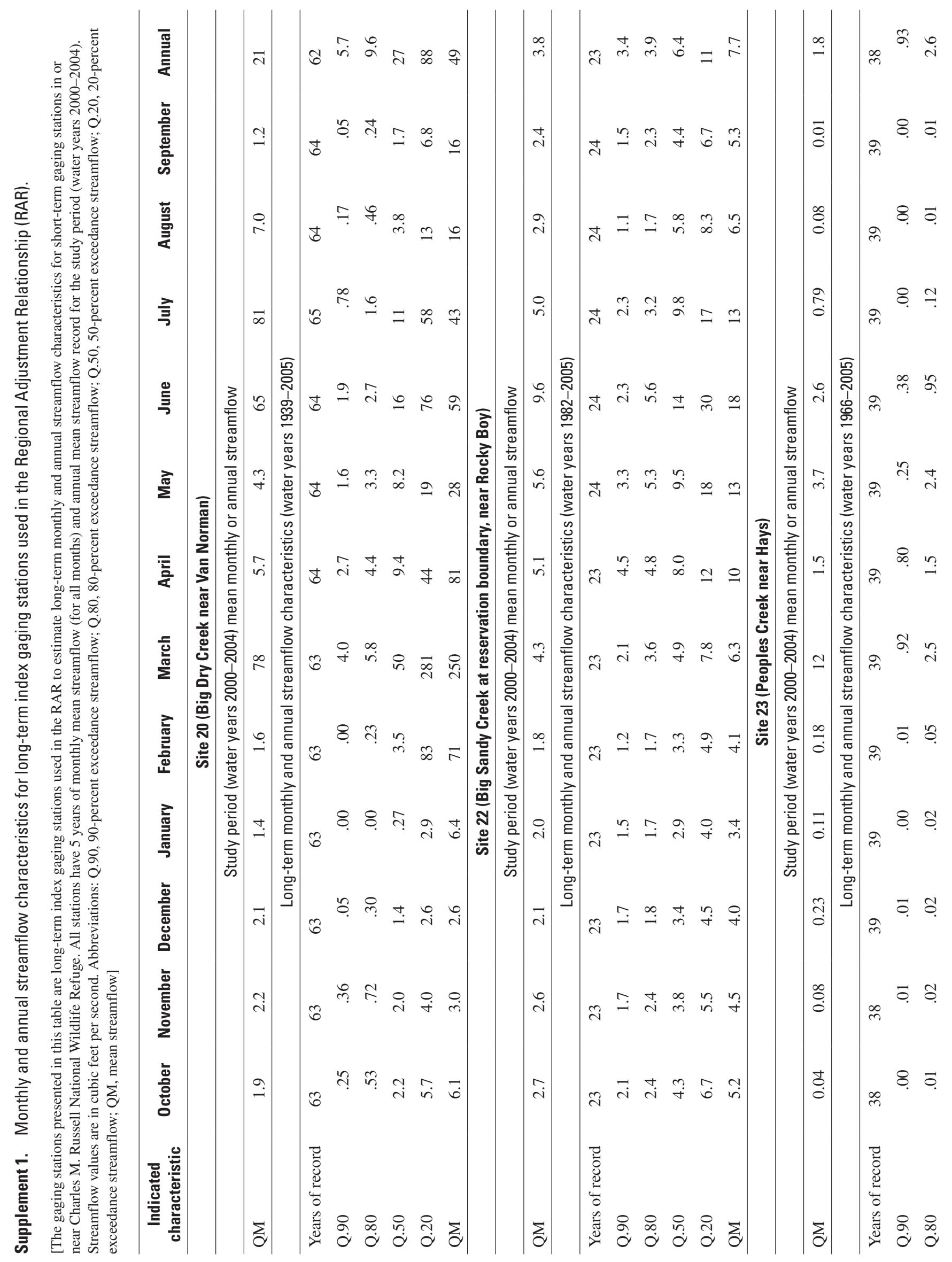




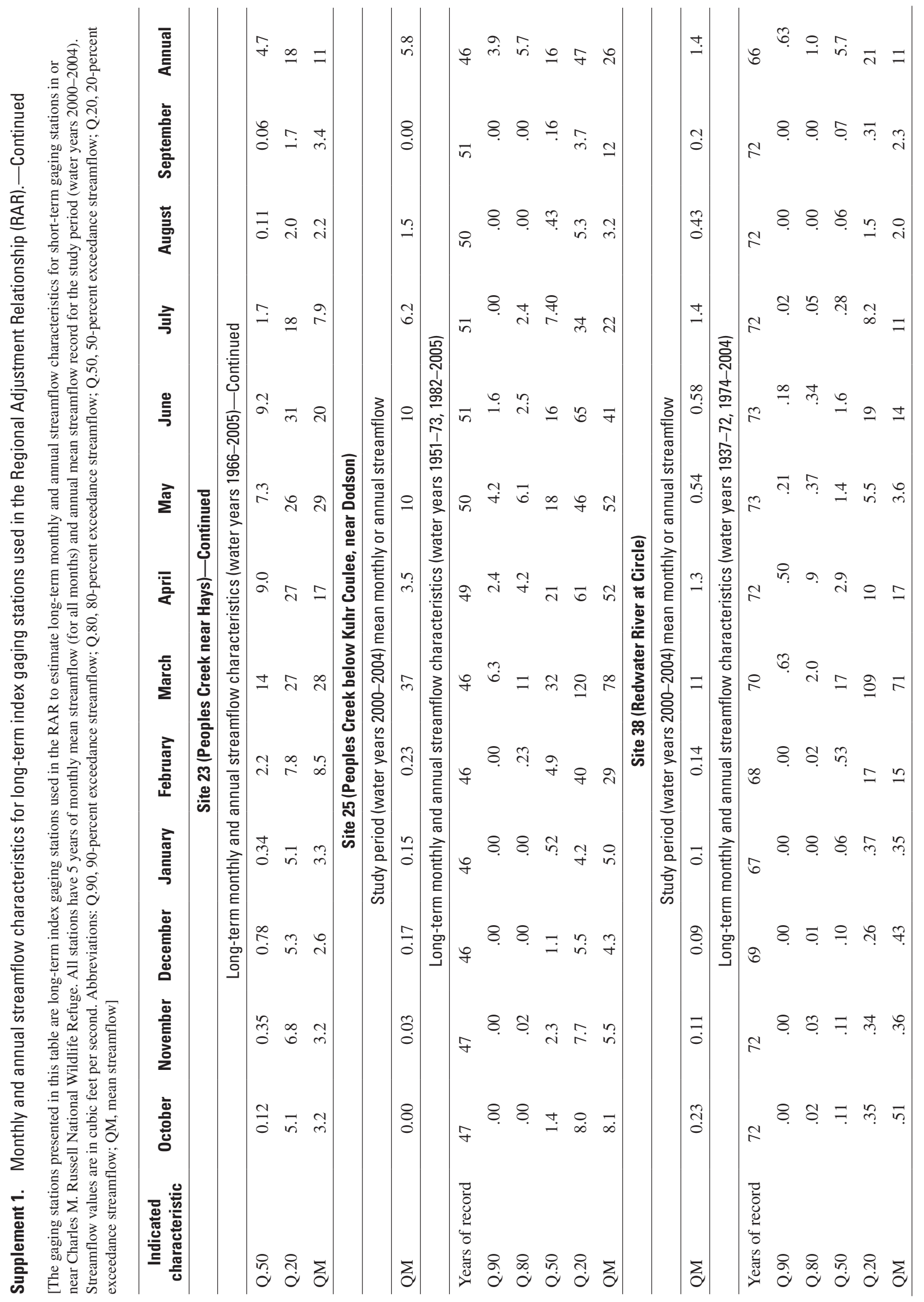




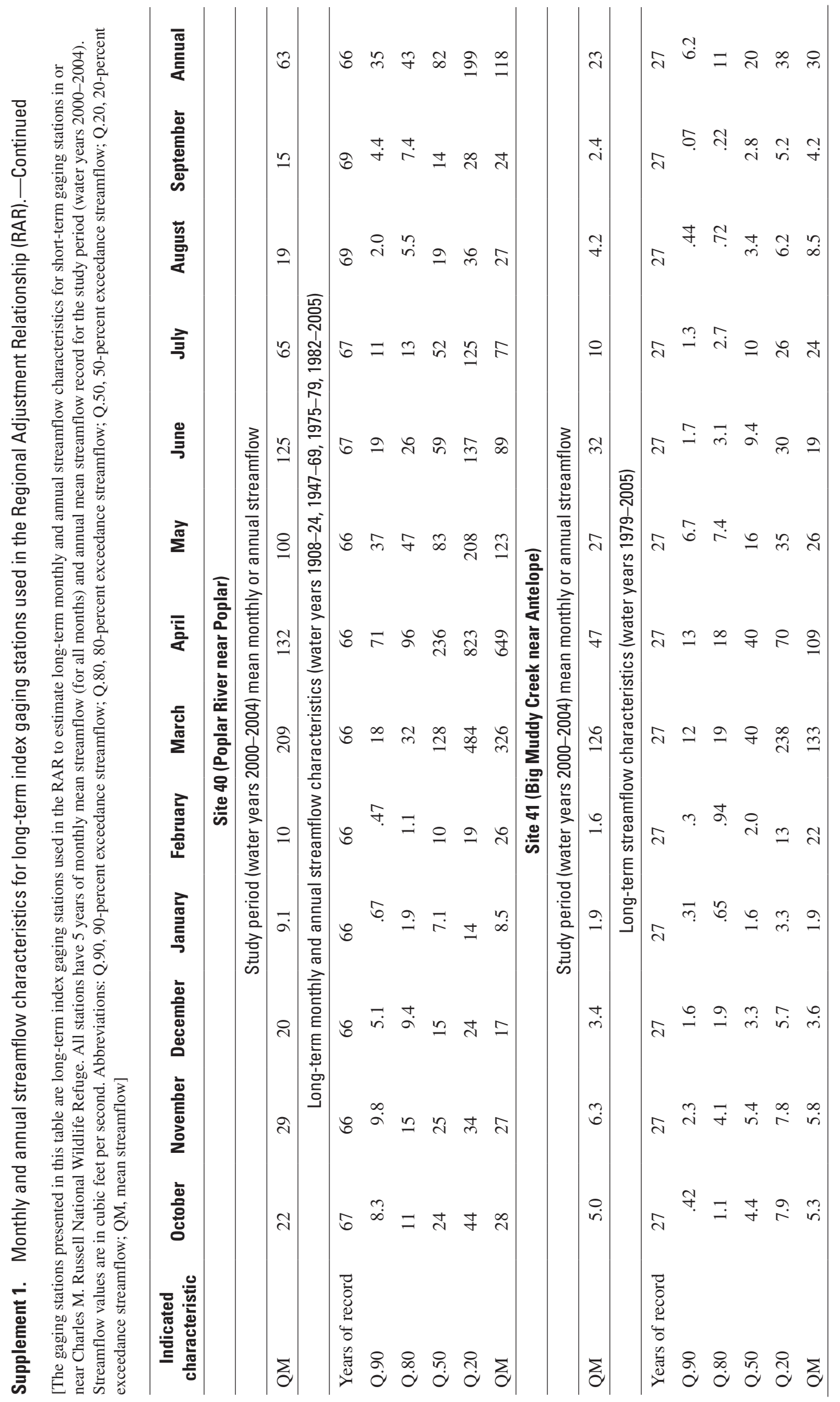




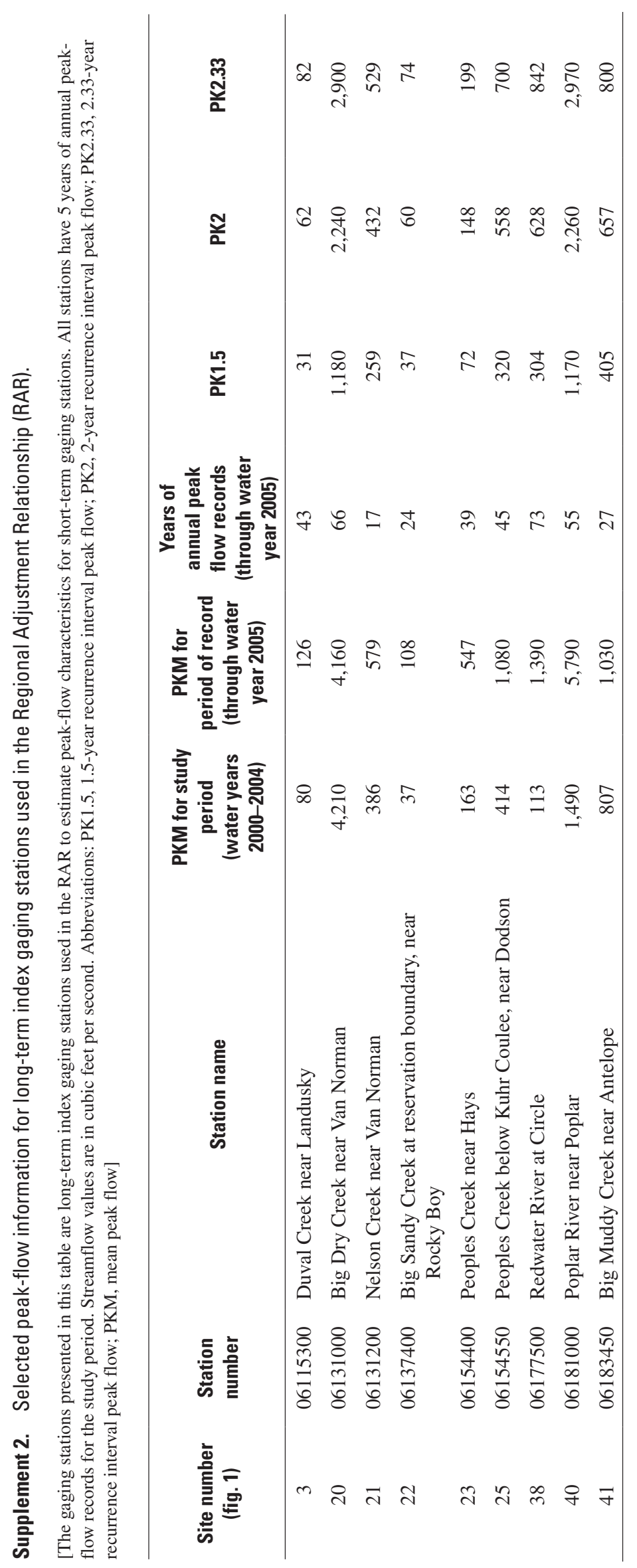




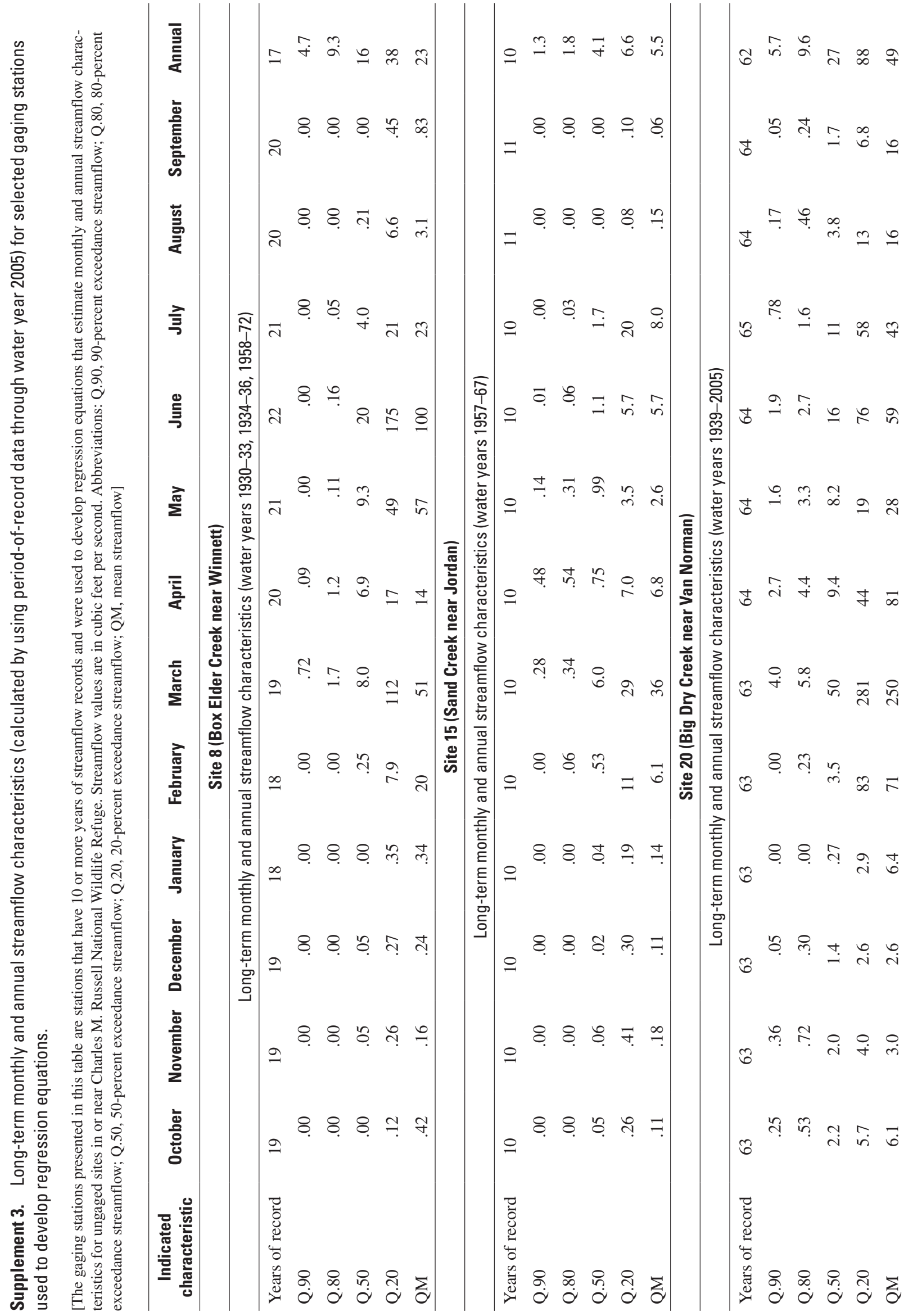




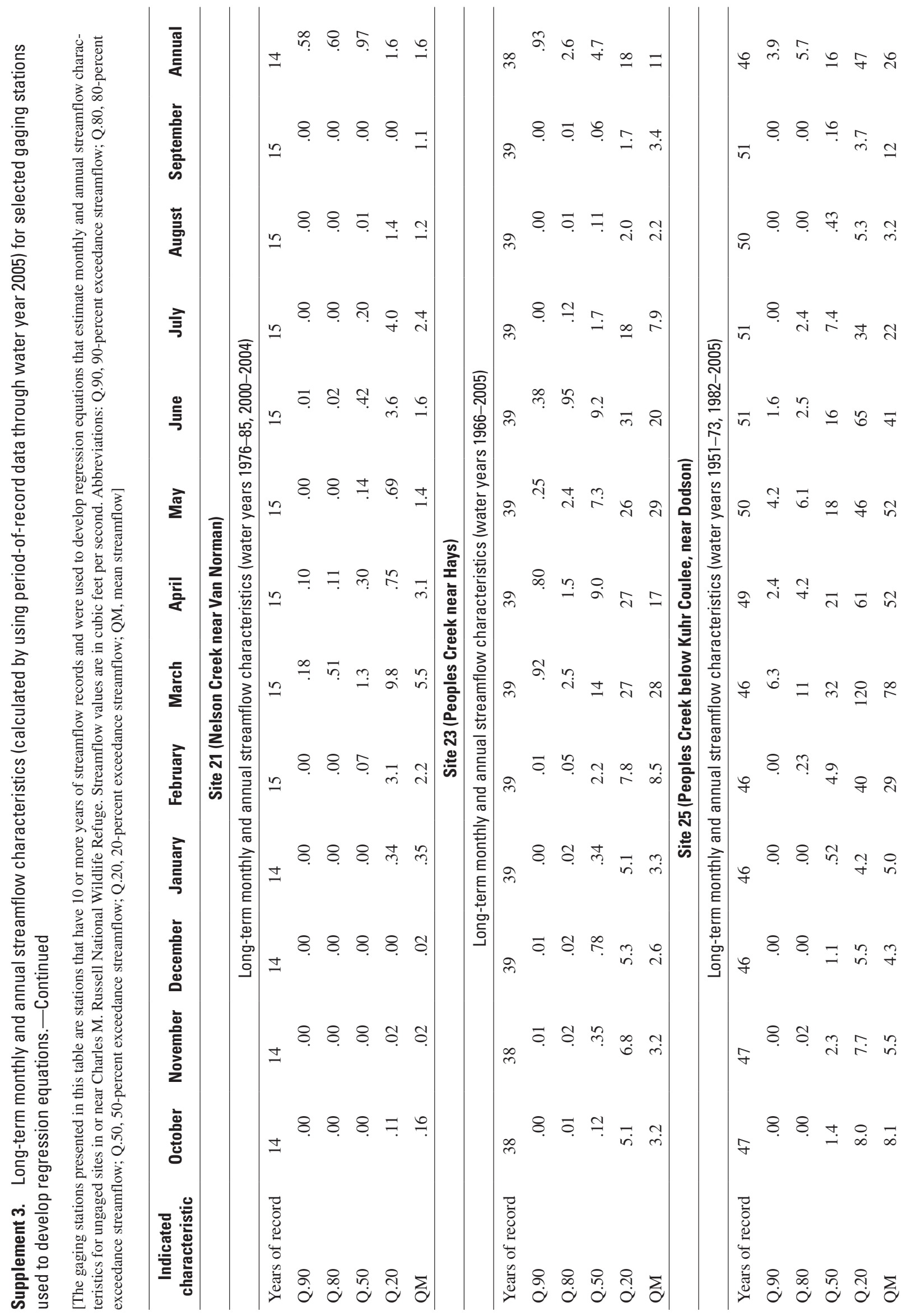




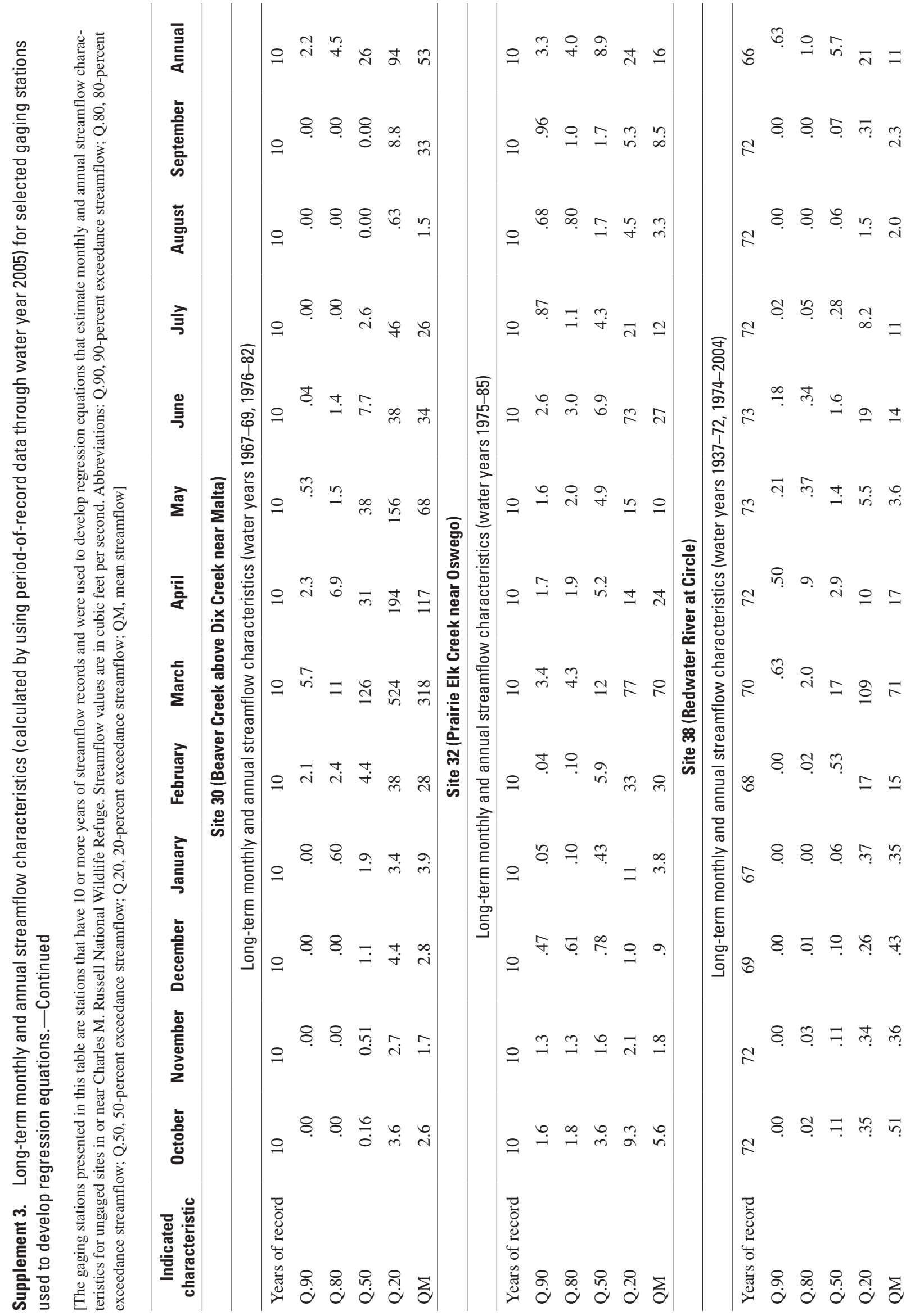




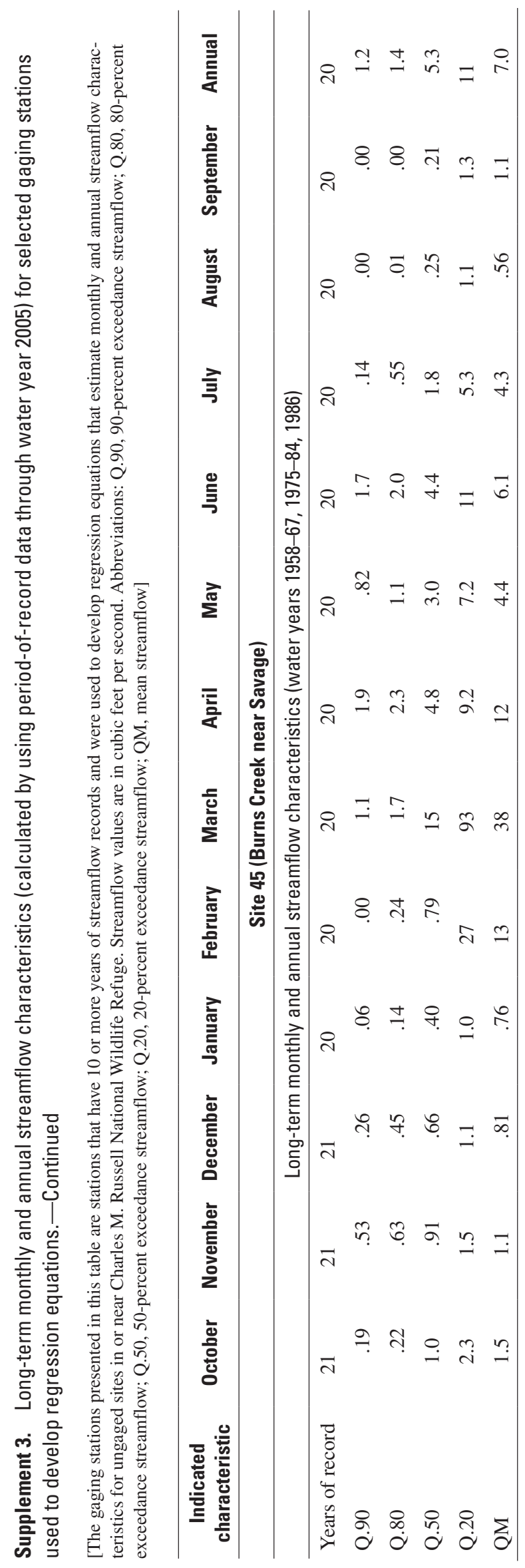




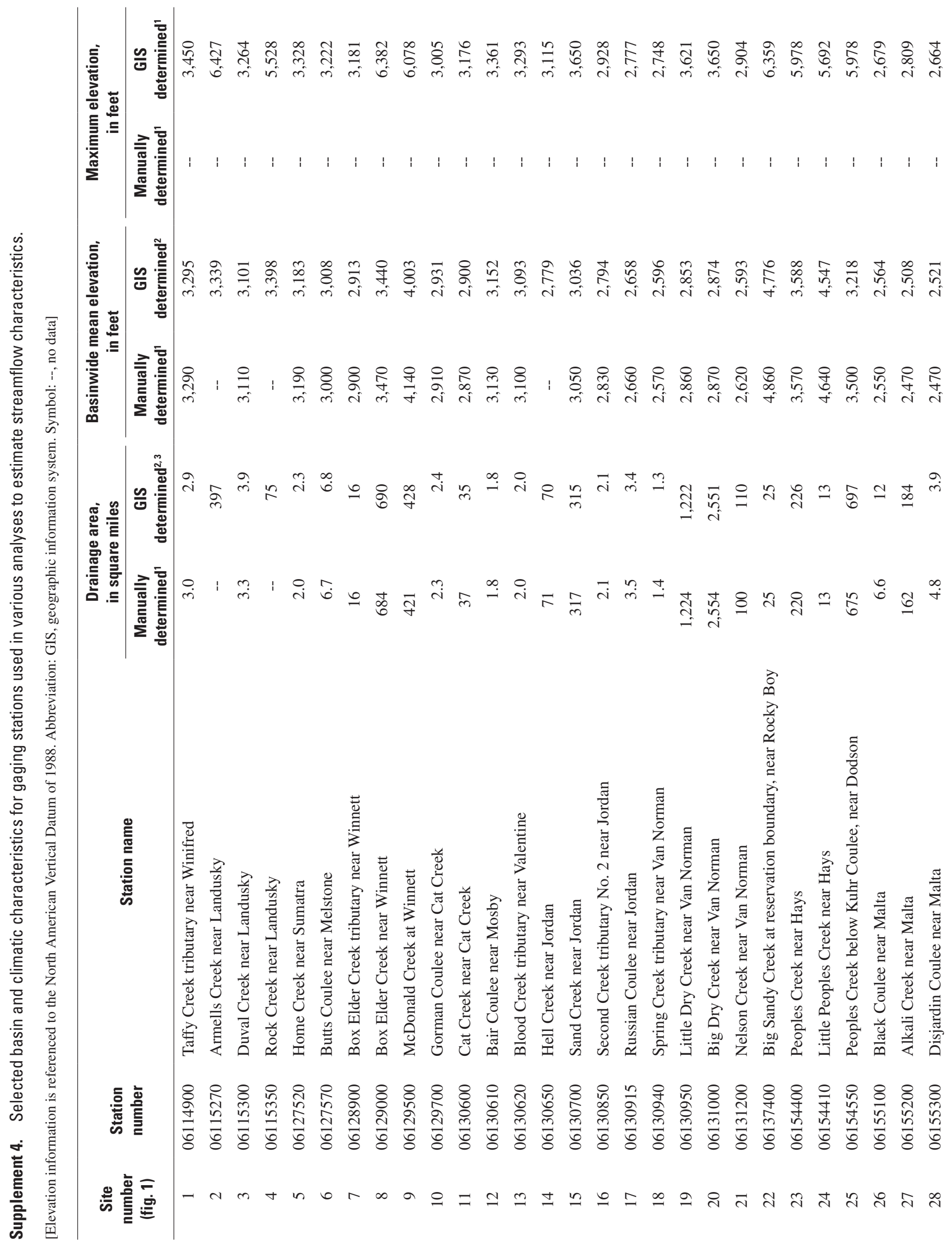




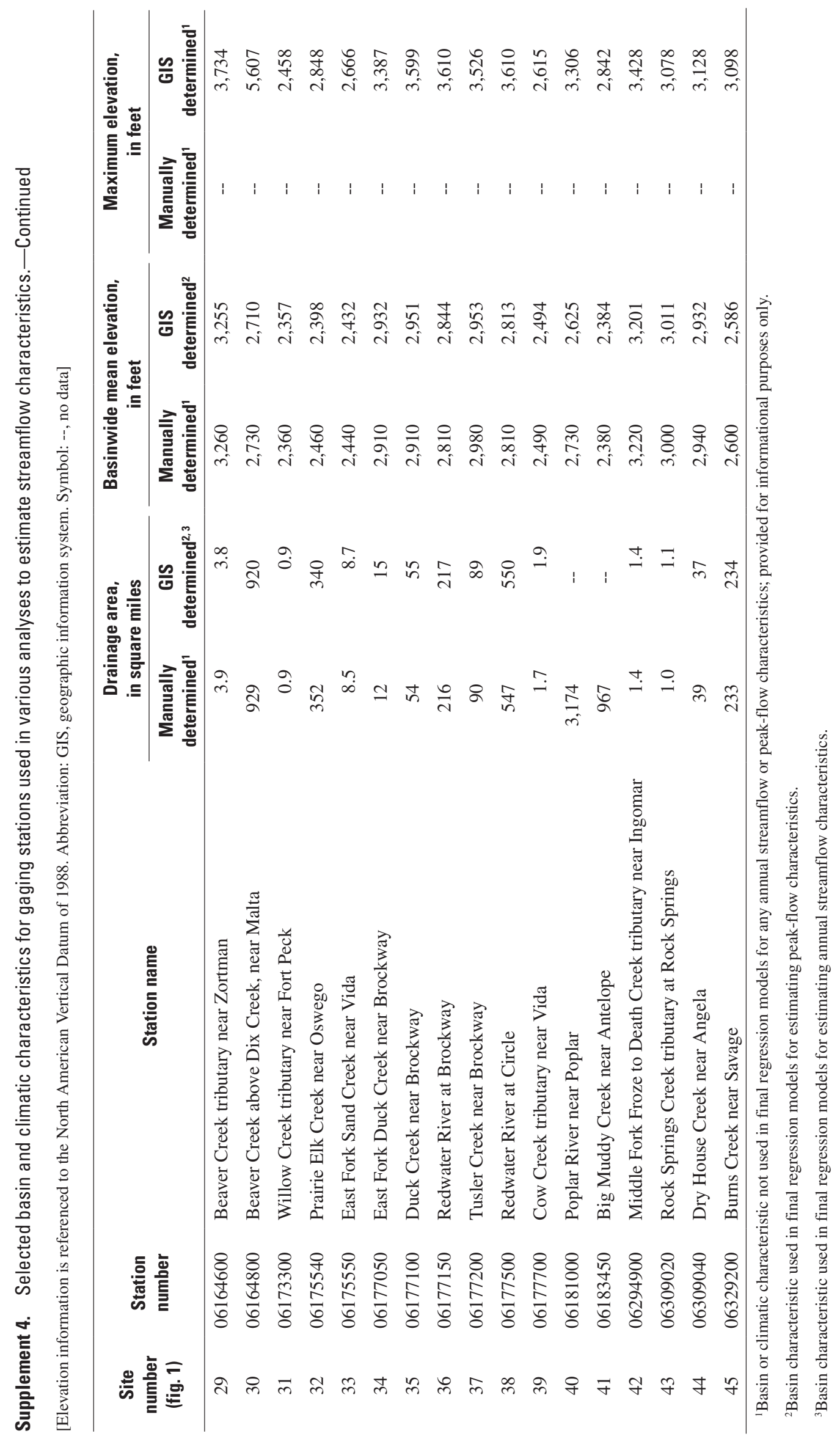


Supplement 5. Selected peak-flow characteristics (calculated by using period-of-record data through water year 2005) for selected gaging stations used to develop regression equations.

[The gaging stations presented in this table are stations that have 10 or more years of annual peak-flow records and were used to develop regression equations that estimate peak-flow characteristics for ungaged sites. Streamflow values are in cubic feet per second. Abbreviations: PK1.5, 1.5-year recurrence interval peak flow; PK2, 2-year recurrence interval peak flow; PK2.33, 2.33-year recurrence interval peak flow]

\begin{tabular}{|c|c|c|c|c|c|c|}
\hline $\begin{array}{c}\text { Site } \\
\text { number } \\
\text { (fig. 1) }\end{array}$ & $\begin{array}{l}\text { Station } \\
\text { number }\end{array}$ & Station name & $\begin{array}{c}\text { Years of } \\
\text { annual peak } \\
\text { records }\end{array}$ & PK1.5 & PK2 & PK2.33 \\
\hline 1 & 06114900 & Taffy Creek tributary near Winifred & 29 & 29 & 48 & 58 \\
\hline 3 & 06115300 & Duval Creek near Landusky & 43 & 31 & 62 & 82 \\
\hline 5 & 06127520 & Home Creek near Sumatra & 33 & 13 & 26 & 34 \\
\hline 6 & 06127570 & Butts Coulee near Melstone & 43 & 54 & 84 & 100 \\
\hline 7 & 06128900 & Box Elder Creek tributary near Winnett & 19 & 81 & 124 & 147 \\
\hline 8 & 06129000 & Box Elder Creek near Winnett & 20 & 867 & 1,270 & 1,490 \\
\hline 9 & 06129500 & McDonald Creek at Winnett & 36 & 223 & 338 & 401 \\
\hline 10 & 06129700 & Gorman Coulee near Cat Creek & 33 & 32 & 71 & 98 \\
\hline 11 & 06130600 & Cat Creek near Cat Creek & 18 & 60 & 93 & 111 \\
\hline 12 & 06130610 & Bair Coulee near Mosby & 32 & 7.4 & 16 & 22 \\
\hline 13 & 06130620 & Blood Creek tributary near Valentine & 32 & 4.1 & 8.2 & 11 \\
\hline 15 & 06130700 & Sand Creek near Jordan & 11 & 414 & 647 & 780 \\
\hline 16 & 06130850 & Second Creek tributary No. 2 near Jordan & 33 & 12 & 24 & 31 \\
\hline 17 & 06130915 & Russian Coulee near Jordan & 32 & 21 & 36 & 46 \\
\hline 18 & 06130940 & Spring Creek tributary near Van Norman & 32 & 22 & 39 & 49 \\
\hline 19 & 06130950 & Little Dry Creek near Van Norman & 20 & 1,510 & 2,130 & 2,450 \\
\hline 20 & 06131000 & Big Dry Creek near Van Norman & 66 & 1,180 & 2,240 & 2,900 \\
\hline 21 & 06131200 & Nelson Creek near Van Norman & 17 & 259 & 432 & 529 \\
\hline 23 & 06154400 & Peoples Creek near Hays & 39 & 72 & 148 & 199 \\
\hline 24 & 06154410 & Little Peoples Creek near Hays & 33 & 25 & 42 & 53 \\
\hline 25 & 06154550 & Peoples Creek below Kuhr Coulee, near Dodson & 45 & 320 & 558 & 700 \\
\hline 26 & 06155100 & Black Coulee near Malta & 13 & 49 & 73 & 88 \\
\hline 27 & 06155200 & Alkali Creek near Malta & 18 & 66 & 149 & 209 \\
\hline 28 & 06155300 & Disjardin Coulee near Malta & 47 & 17 & 27 & 33 \\
\hline 29 & 06164600 & Beaver Creek tributary near Zortman & 32 & 31 & 55 & 70 \\
\hline 30 & 06164800 & Beaver Creek above Dix Creek, near Malta & 12 & 355 & 831 & 1,170 \\
\hline 31 & 06173300 & Willow Creek tributary near Fort Peck & 19 & 24 & 47 & 62 \\
\hline 32 & 06175540 & Prairie Elk Creek near Oswego & 10 & 690 & 1,050 & 1,250 \\
\hline 33 & 06175550 & East Fork Sand Creek near Vida & 15 & 112 & 178 & 216 \\
\hline 34 & 06177050 & East Fork Duck Creek near Brockway & 48 & 44 & 75 & 94 \\
\hline 35 & 06177100 & Duck Creek near Brockway & 17 & 77 & 164 & 222 \\
\hline 36 & 06177150 & Redwater River at Brockway & 18 & 315 & 558 & 701 \\
\hline 37 & 06177200 & Tusler Creek near Brockway & 16 & 82 & 140 & 173 \\
\hline 38 & 06177500 & Redwater River at Circle & 73 & 304 & 628 & 842 \\
\hline 39 & 06177700 & Cow Creek tributary near Vida & 43 & 32 & 65 & 87 \\
\hline 42 & 06294900 & Middle Fork Froze to Death Creek tributary near Ingomar & 15 & 50 & 69 & 79 \\
\hline 43 & 06309020 & Rock Springs Creek tributary at Rock Springs & 17 & 6.1 & 10 & 12 \\
\hline 44 & 06309040 & Dry House Creek near Angela & 16 & 73 & 144 & 190 \\
\hline 45 & 06329200 & Burns Creek near Savage & 21 & 158 & 311 & 409 \\
\hline
\end{tabular}




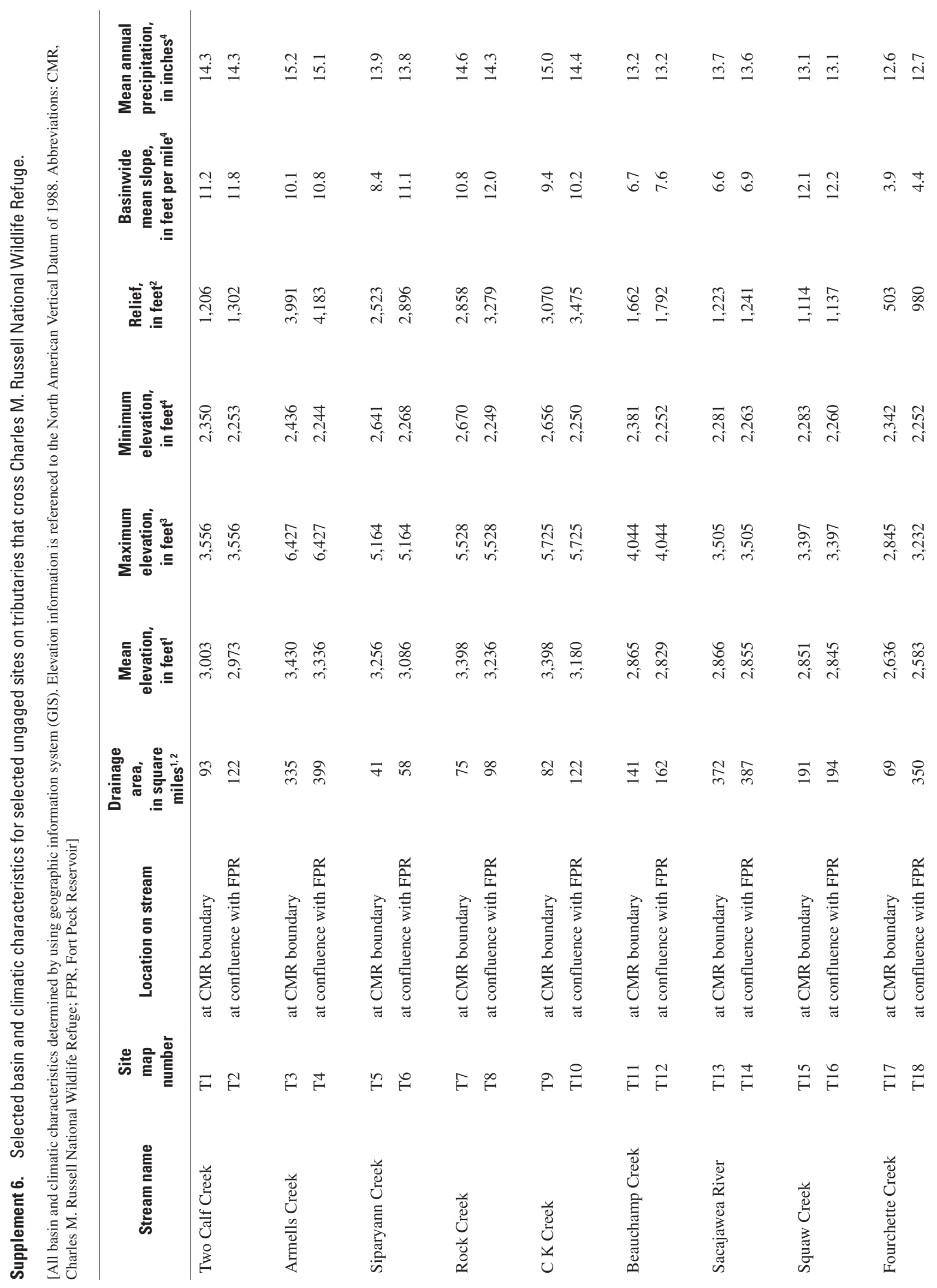




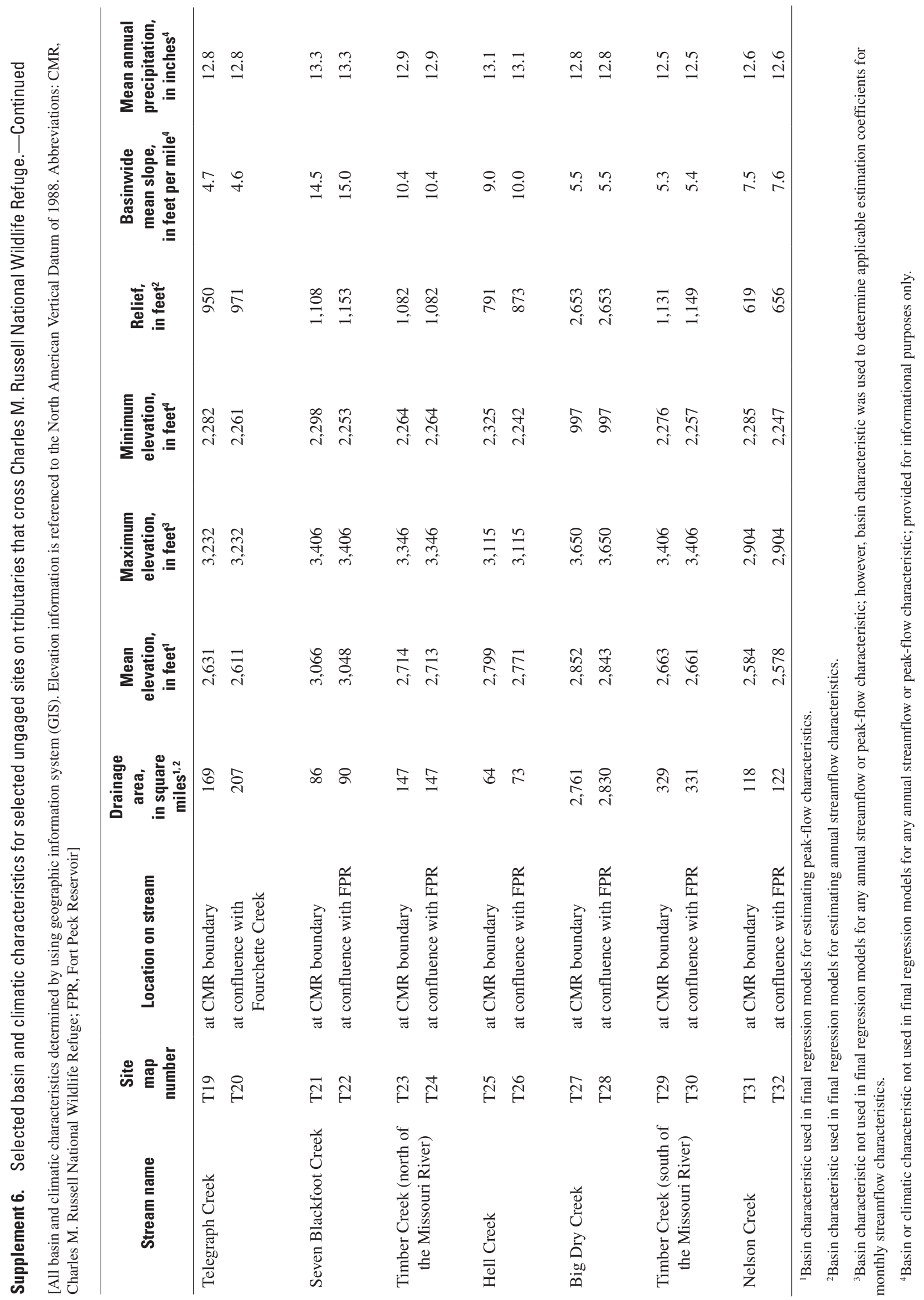




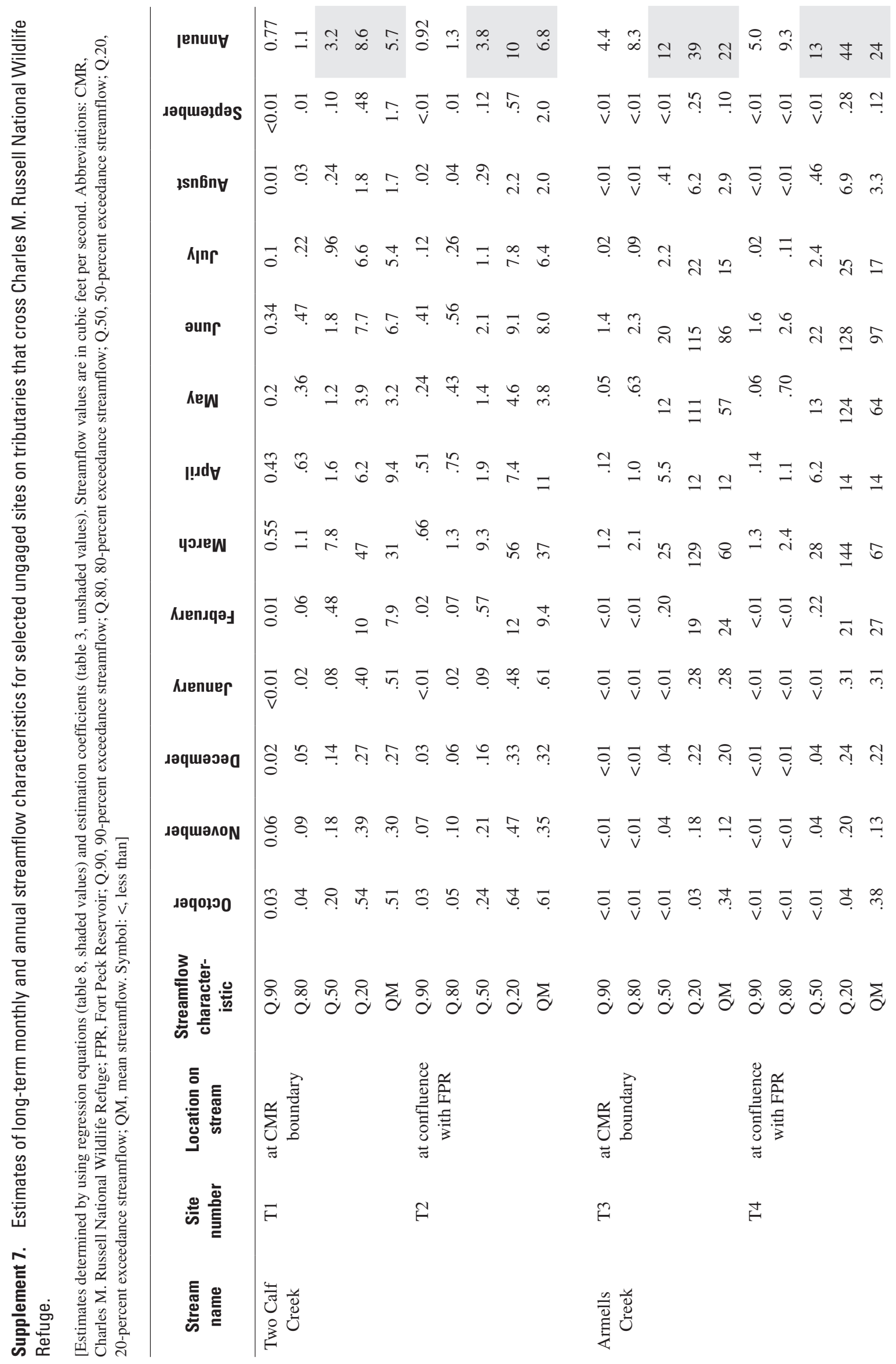




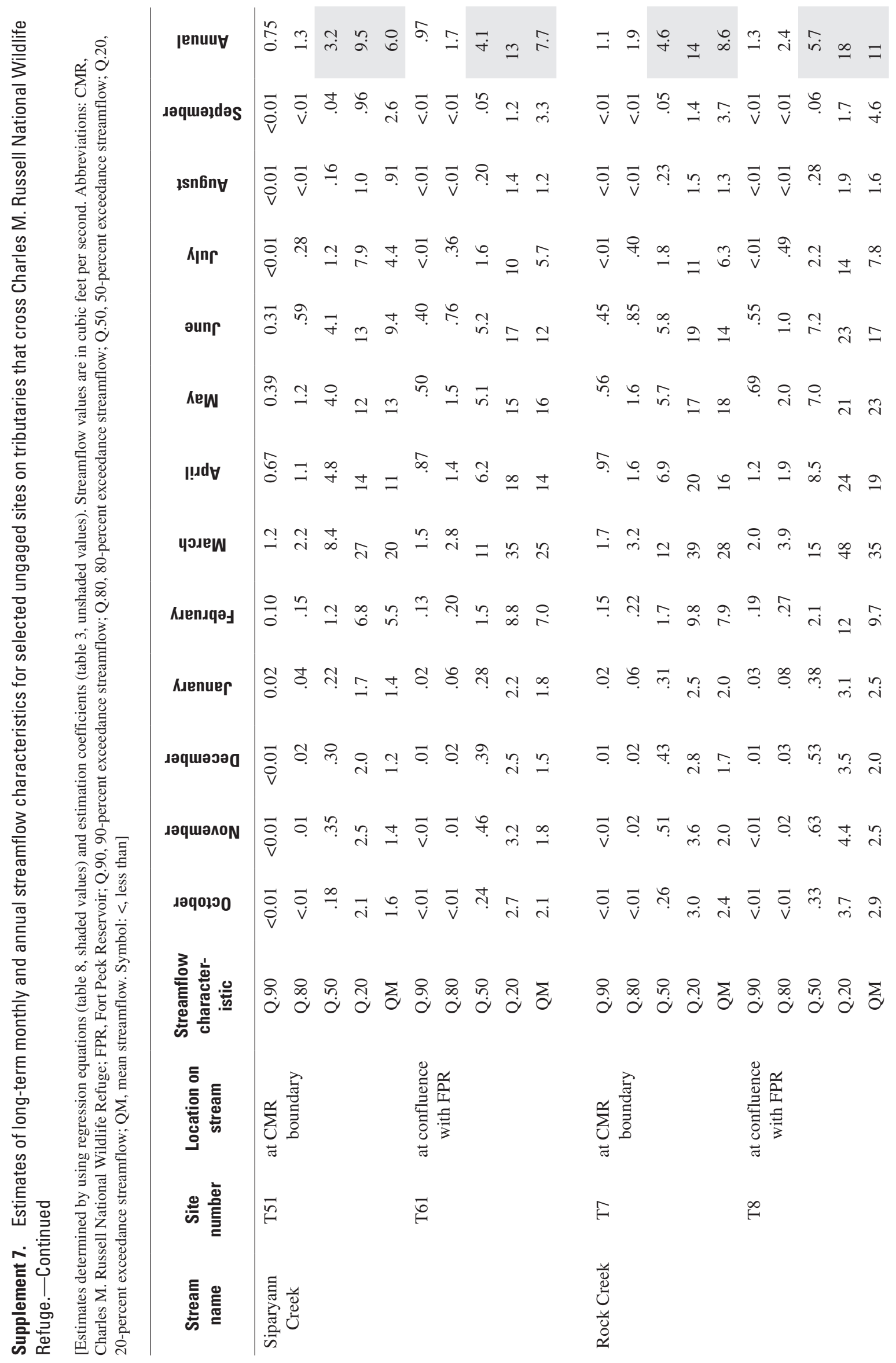




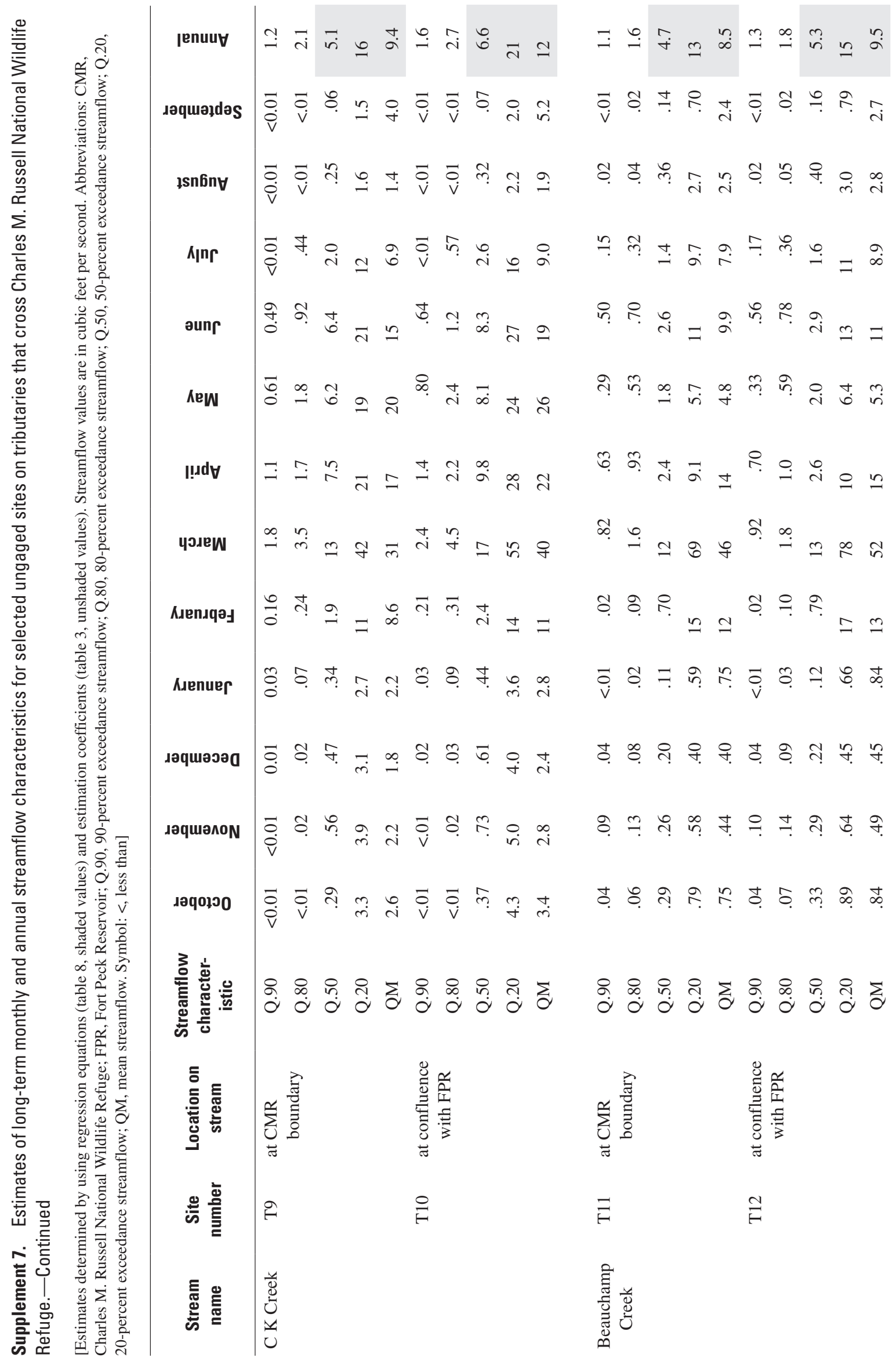




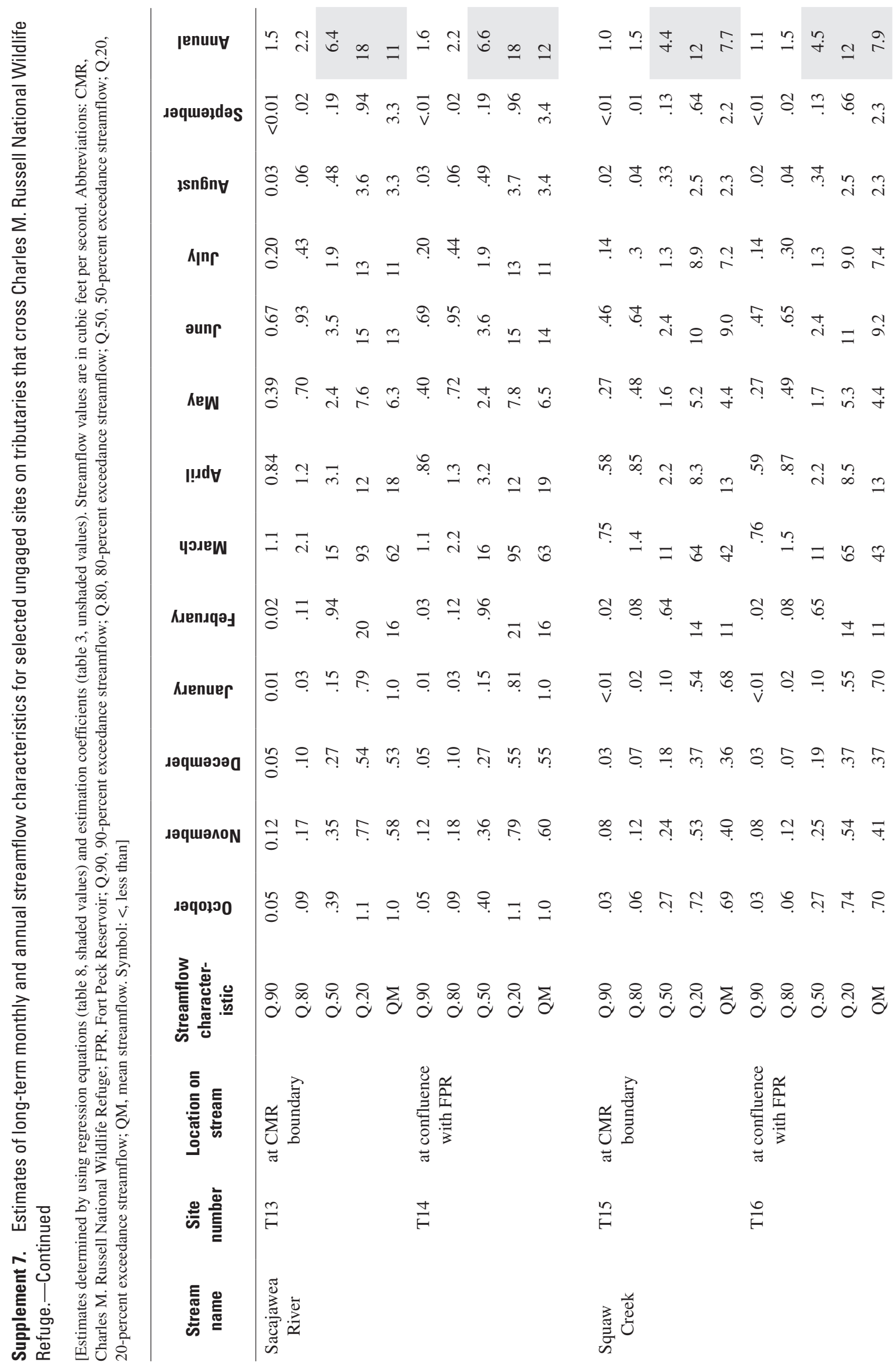




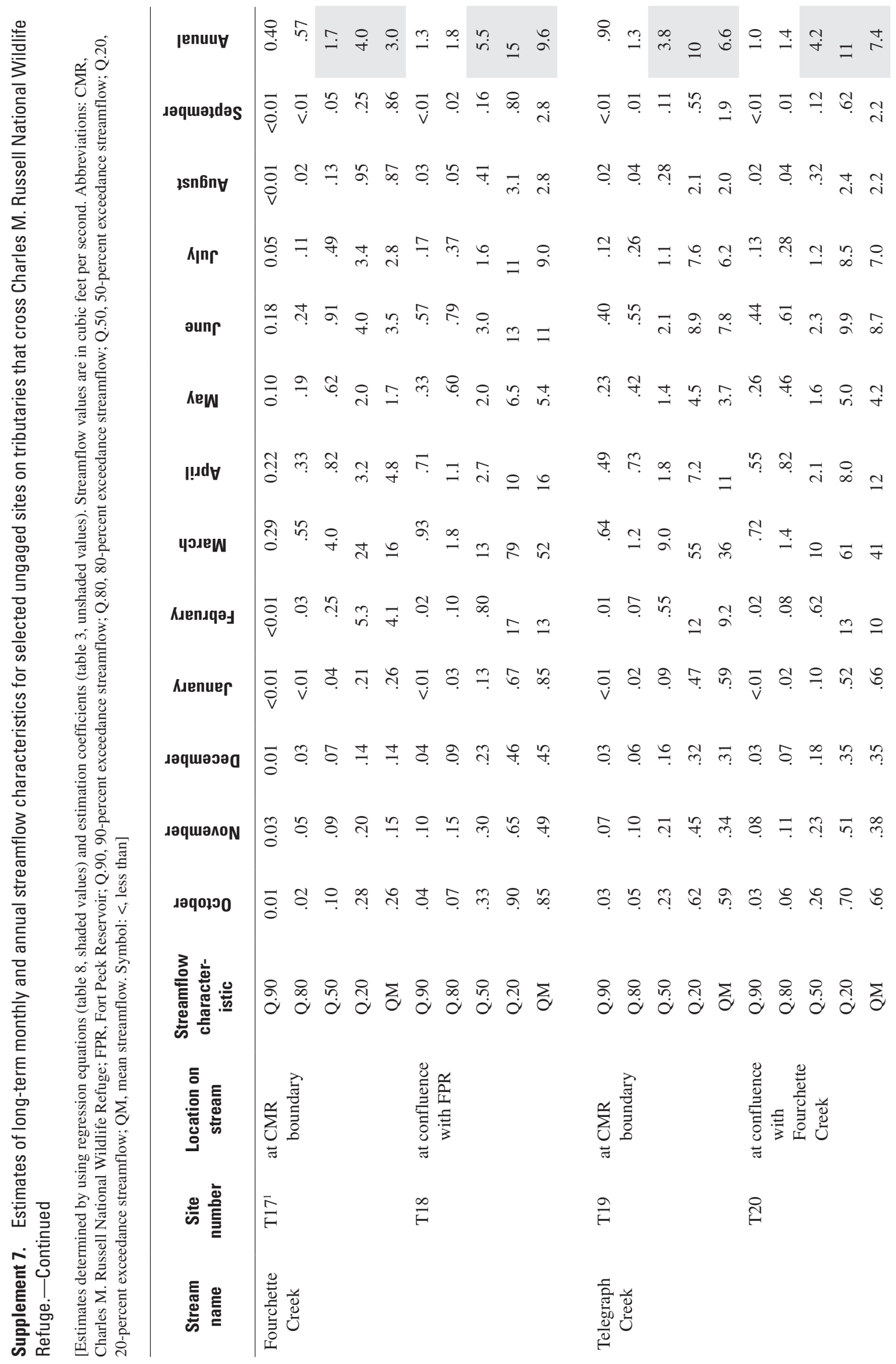




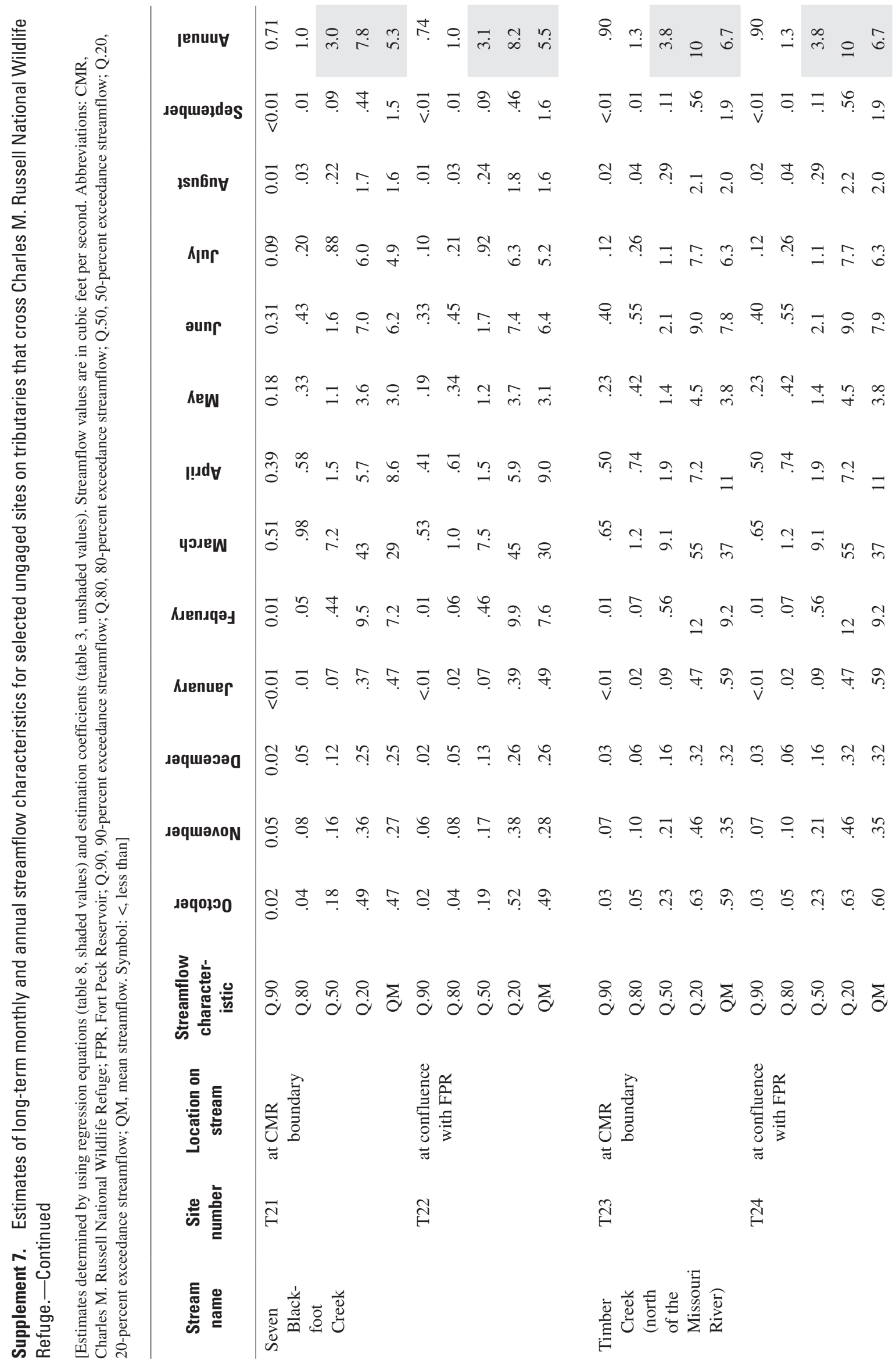




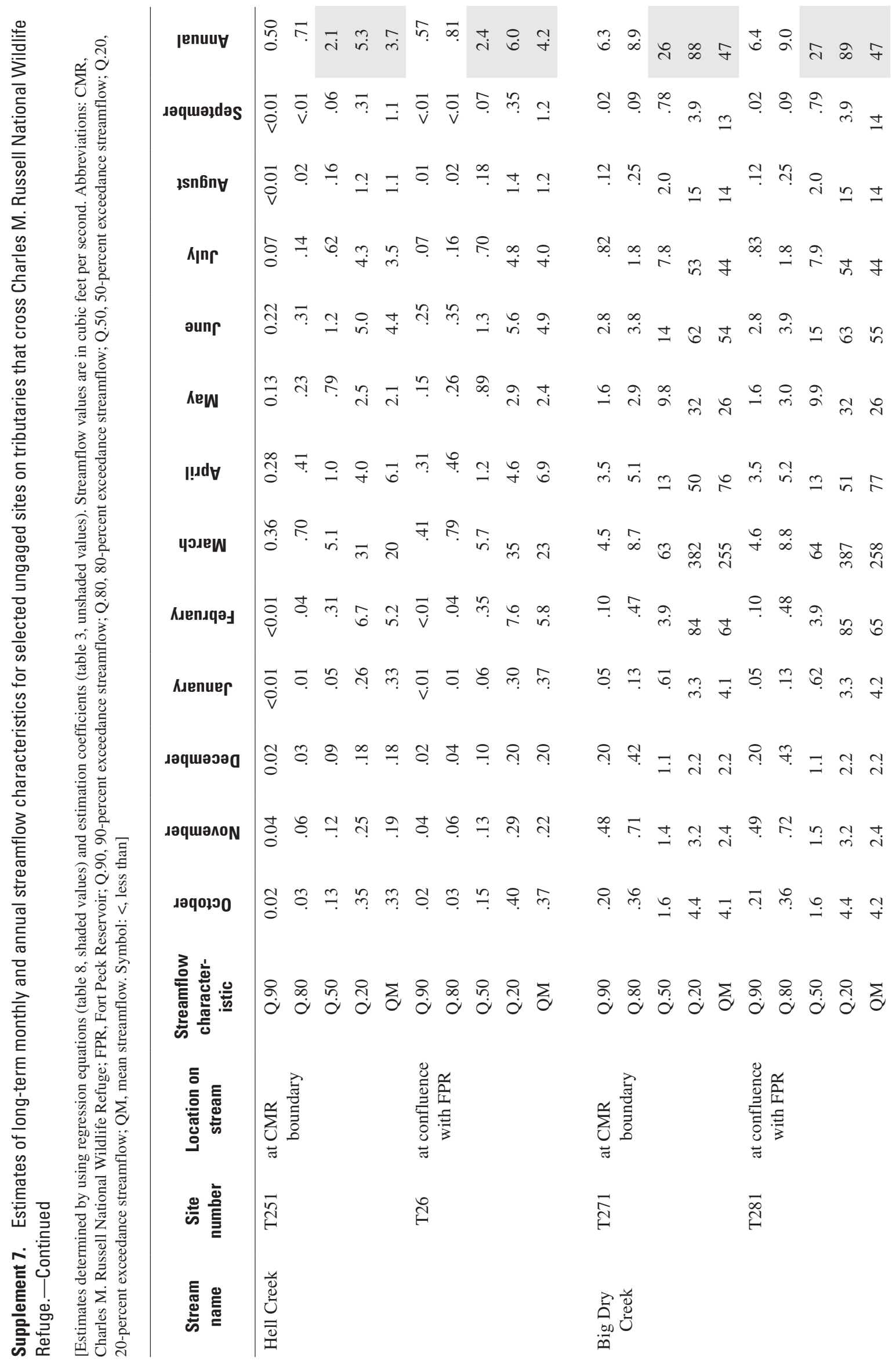




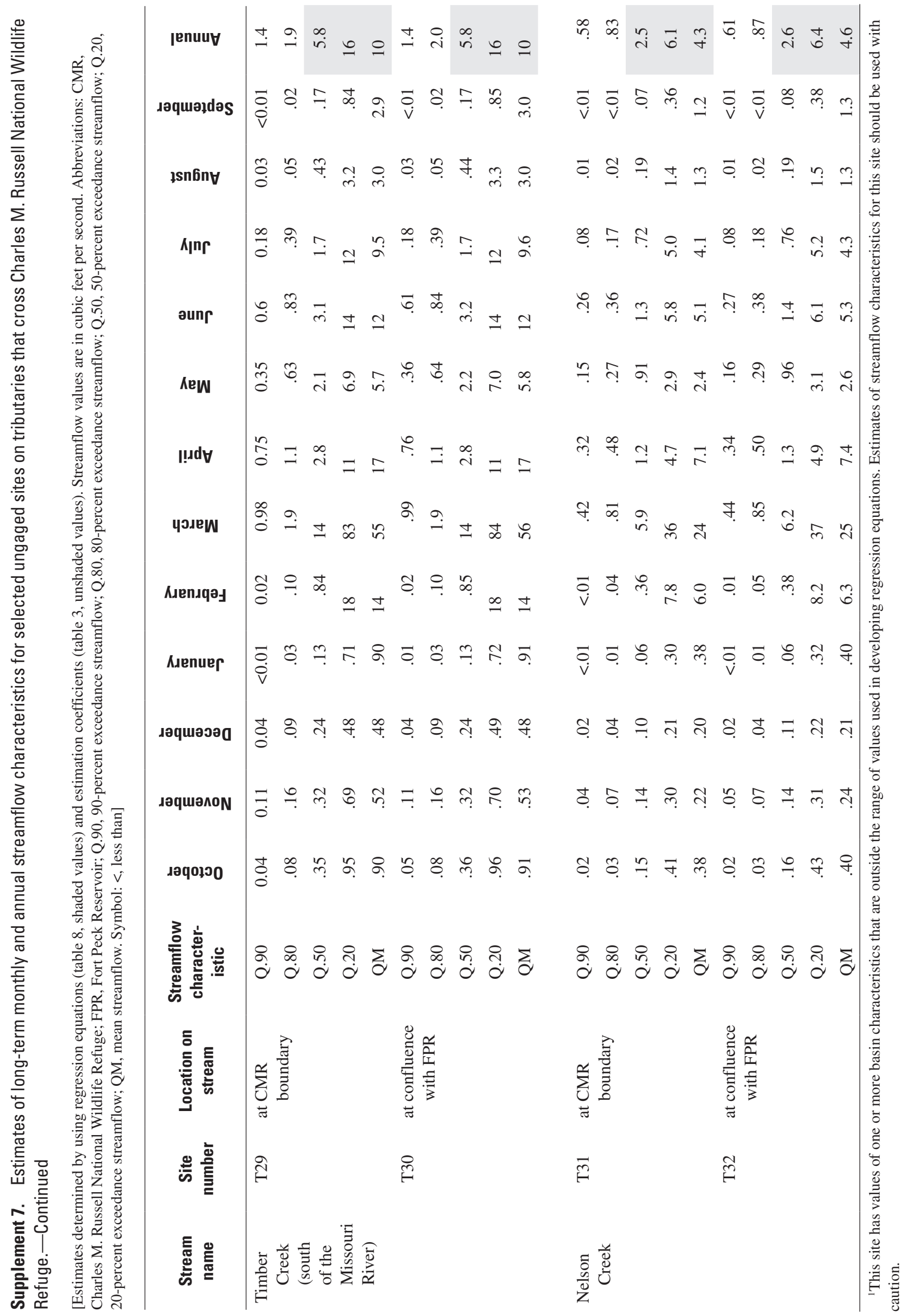


Supplement 8. Estimates of selected peak-flow characteristics for selected ungaged sites on tributaries that cross Charles M. Russell National Wildlife Refuge.

[Estimates determined by using regression equations (table 9). Streamflow values are in cubic feet per second. Abbreviations: CMR, Charles M. Russell National Wildlife Refuge; FPR, Fort Peck Reservoir; PK1.5, 1.5-year recurrence interval peak flow; PK2, 2-year recurrence interval peak flow; PK2.33, 2.33-year recurrence interval peak flow. Streamflow values are in cubic feet per second]

\begin{tabular}{|c|c|c|c|c|c|c|}
\hline Stream name & $\begin{array}{c}\text { Site } \\
\text { number }\end{array}$ & Region & Location on stream & PK1.5 & PK2 & PK2.33 \\
\hline \multirow[t]{2}{*}{ Two Calf Creek } & $\mathrm{T} 1$ & South & at CMR boundary & 173 & 297 & 369 \\
\hline & $\mathrm{T} 2$ & & at confluence with FPR & 208 & 357 & 443 \\
\hline \multirow[t]{2}{*}{ Armells Creek } & $\mathrm{T} 3$ & South & at CMR boundary & 301 & 497 & 606 \\
\hline & $\mathrm{T} 4$ & & at confluence with FPR & 353 & 582 & 709 \\
\hline \multirow[t]{2}{*}{ Siparyann Creek } & $\mathrm{T} 5$ & North & at CMR boundary & 72 & 138 & 183 \\
\hline & T6 & & at confluence with FPR & 83 & 160 & 214 \\
\hline \multirow[t]{2}{*}{ Rock Creek } & $\mathrm{T} 7$ & North & at CMR boundary & 92 & 178 & 238 \\
\hline & $\mathrm{T} 8$ & & at confluence with FPR & 102 & 200 & 267 \\
\hline \multirow[t]{2}{*}{ C K Creek } & $\mathrm{T} 9$ & North & at CMR boundary & 95 & 186 & 248 \\
\hline & $\mathrm{T} 10$ & & at confluence with FPR & 111 & 219 & 294 \\
\hline \multirow[t]{2}{*}{ Beauchamp Creek } & $\mathrm{T} 11$ & North & at CMR boundary & 118 & 233 & 312 \\
\hline & $\mathrm{T} 12$ & & at confluence with FPR & 124 & 247 & 332 \\
\hline \multirow[t]{2}{*}{ Sacajawea River } & $\mathrm{T} 13$ & South & at CMR boundary & 445 & 748 & 919 \\
\hline & $\mathrm{T} 14$ & & at confluence with FPR & 459 & 772 & 947 \\
\hline \multirow[t]{2}{*}{ Squaw Creek } & $\mathrm{T} 15$ & South & at CMR boundary & 296 & 506 & 626 \\
\hline & $\mathrm{T} 16$ & & at confluence with FPR & 301 & 513 & 635 \\
\hline \multirow[t]{2}{*}{ Fourchette Creek } & $\mathrm{T} 17$ & North & at $\mathrm{CMR}$ boundary & 89 & 172 & 229 \\
\hline & $\mathrm{T} 18$ & & at confluence with FPR & 168 & 341 & 462 \\
\hline \multirow[t]{2}{*}{ Telegraph Creek } & T19 & North & at CMR boundary & 126 & 252 & 339 \\
\hline & $\mathrm{T} 20$ & & $\begin{array}{l}\text { at confluence with } \\
\text { Fourchette Creek }\end{array}$ & 137 & 274 & 369 \\
\hline \multirow[t]{2}{*}{ Seven Blackfoot Creek } & $\mathrm{T} 21$ & South & at CMR boundary & 159 & 273 & 339 \\
\hline & $\mathrm{T} 22$ & & at confluence with FPR & 165 & 284 & 352 \\
\hline \multirow{2}{*}{$\begin{array}{l}\text { Timber Creek (north of } \\
\text { the Missouri River) }\end{array}$} & $\mathrm{T} 23$ & North & at CMR boundary & 120 & 237 & 319 \\
\hline & $\mathrm{T} 24$ & & at confluence with FPR & 120 & 237 & 319 \\
\hline
\end{tabular}


Supplement 8. Estimates of selected peak-flow characteristics for selected ungaged sites on tributaries that cross Charles M. Russell National Wildlife Refuge.-Continued

[Estimates determined by using regression equations (table 9). Streamflow values are in cubic feet per second. Abbreviations: CMR, Charles M. Russell National Wildlife Refuge; FPR, Fort Peck Reservoir; PK1.5, 1.5-year recurrence interval peak flow; PK2, 2-year recurrence interval peak flow; PK2.33, 2.33-year recurrence interval peak flow. Streamflow values are in cubic feet per second]

\begin{tabular}{lcccccc}
\hline \multicolumn{1}{c}{ Stream name } & $\begin{array}{c}\text { Site } \\
\text { number }\end{array}$ & Region & Location on stream & PK1.5 & PK2 & PK2.33 \\
\hline Hell Creek & T25 & South & at CMR boundary & 156 & 272 & 340 \\
& T26 & & at confluence with FPR & 172 & 300 & 375 \\
& & & & & & \\
Big Dry Creek & T27 & South & at CMR boundary & 1,550 & 2,510 & 3,020 \\
& T28 & & at confluence with FPR & 1,590 & 2,560 & 3,090 \\
Timber Creek (south of & T29 & \multirow{2}{*}{ South } & at CMR boundary & 470 & 800 & 987 \\
the Missouri River) & T30 & & at confluence with FPR & 472 & 804 & 992 \\
Nelson Creek & & & & & & \\
& T31 & South & at CMR boundary & 262 & 457 & 571 \\
& T32 & & at confluence with FPR & 269 & 468 & 585 \\
\hline
\end{tabular}

Publishing support provided by:

Helena Publishing Service Center

For more information concerning this publication, contact:

Director, USGS Montana Water Science Center

3162 Bozeman Ave.

Helena, MT 59601

(406) 457-5900

Or visit the Montana Water Science Center Web site at:

http://mt.water.usgs.gov 

ISBN 978-l-4l13-2352-0 